\title{
RELINK: \\ LIFELINE IN EQALUIT
}

B y

Assal Bakhshandeh

A thesis submitted to the Faculty of Graduate and

Postdoctoral Affairs

In partial fulfillment of the requirements for the degree of

Master of Architecture

in

M.ARCH (Professional)

Azrieli School of Architecture and Urbanism

Carleton University,

Ottawa, Canada

(C) 2018

Assal Bakhshandeh 
RELINK:

LIFELINE IN EQALUIT 

A B STRACT

Re[link]-Lifeline in Iqaluit

Project Type: Conceptual Design

Team No.: Individual

Location: Iqaluit. Nunavut

Year: $\quad 2018$ 
Architects draw. Drawing is fundamental to architectural thinking, communication and organization and this thesis explores the nature of architectural drawing by using speculative drawing methods as a form of research.

Architecture is not revolutionary itself, but has the capacity to position information in relationships that are a catalyst for creating productive dialog between inter-connected technological, environmental and societal systems. The speculative spaces produced in this work create new and multiple narratives through complexity on this site. As such, the drawings of the project are an examination of the abstract spatial possibilities, with particular attention to the quantifiable needs on such a challenging site. The speculative spaces produced through this process can be read as new narratives, new possibilities and new organizational structures for spatial thinking in the North.

The Arctic is an extreme landscape and sea ice is a significant factor in navigation and access in this area. It is unlike any other environment on earth and the approach to this work is sensitive to how one perceives this place. Architectural conventions are built on a common set of rules for perceiving and measuring space. Drawing from local cultural practices, this thesis investigates alternative drawing methods for an environment that is not easily perceived or measured by known architectural conventions. 


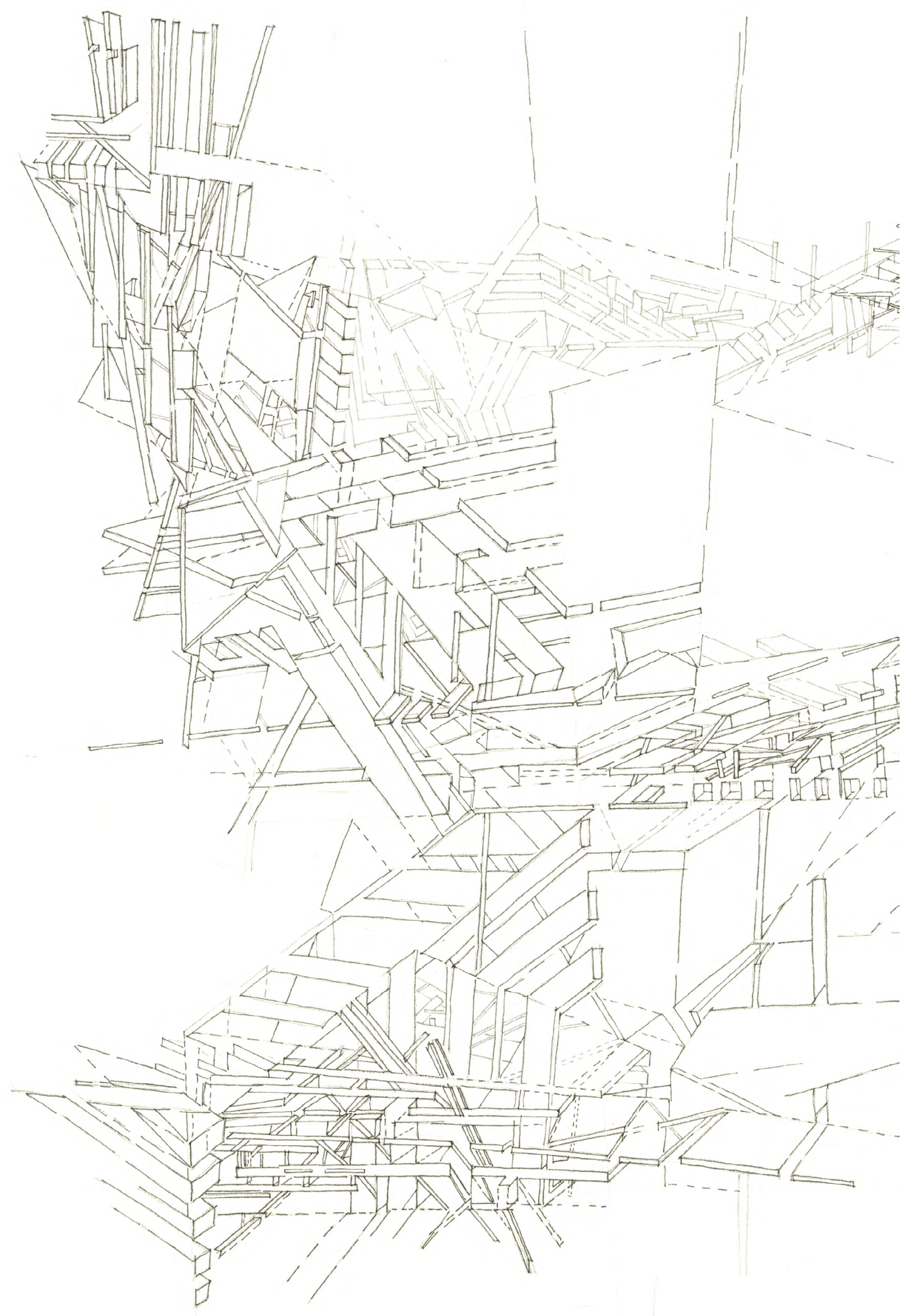




\section{ACKNOWLEDGEMENT}

I would like to thank my advisor, Zachary Colbert for all his support and encouragements. I am honoured to be his student and to have experienced true fiction under his advisory.

I was fortunate to have had Jill Stoner as a professor and a theoretical guru. Thank you for helping to frame my thesis topic.

Thank you to my mother, Zahra, for always being there to respond to my premature hypothesis and countless conversations. She deserves more thanks than I can possibly put into words.

Thank you for all your support; without you I would have never imagined myself here now. 


\section{TABLE OF CONTENTS}

INDEX

ABSTRACT

ACKNOWLEDGEMENT

LIST OF TABLES ix

LIST OF ILLUSTRATION

INTRODUCTION

OBJECTIVE OF THESIS 5

CHAPTERS

1-SITE ANALYSIS 11

2-DRAWING STRATEGY 13

CONCEPT 13

COMPOSITION 39

RENDERING 53

APPENDIX A-site analysis 67

APPENDIX B - SKetChes \& PROCESS 


\section{LIST OF TABLES}

PAGE 7

Lola Sheppard. Mason White. MANY NORTHS, Spatial practice in a polar territory. New York: Actar Publishers. 2017.

\section{PA GE 74}

Iqauit Harbour Shipping Dates. Aaluk Consulting Inc.

Gartner Lee Limited, and Anderson, Chris. "Strategic Plan for the Iqaluit Deepwater Port Project". (2005)

\section{PAGE 74}

Cargo Vessels:Days spent unloading [2003]. Aaluk Consulting Inc. Gartner Lee Limited, and Anderson, Chris. "Strategic Plan for the Iqaluit Deepwater Port Project". (2005)

\section{PAGE 76}

Petroleum Product Tankers [2003]. Aaluk Consulting Inc.

Gartner Lee Limited, and Anderson, Chris. "Strategic Plan for the Iqaluit Deepwater Port Project". (2005)

\section{PAGE 85}

Times and heights for high and low tides. https://www. tide-forecast.com/locations/lqaluit-Nunavut/tides/latest

\section{PAGE 89}

Proforma. Aaluk Consulting Inc. Gartner Lee Limited, and Anderson, Chris. "Strategic Plan for the lqaluit Deepwater Port Project". (2005)

\section{PA GE 90}

Proforma. Aaluk Consulting Inc. Gartner Lee Limited, and Anderson, Chris. "Strategic Plan for the Iqaluit Deepwater Port Project". (2005) 


\section{LIST OF ILLUSTRATION}

PAGE 17

Inuit Traditional Dance. https://www.youtube.com/

watch? $=$ KB-bcO5b-og

PAGE 18

Inuit Traditional Dance. https://www.youtube.com/

watch? $v=K B-b c 05 b-0 g$

PAGE 71

Iqaluit. High tide and Low tide.

PAGE 72

Iqaluit. High tide and Low tide.

PAGE 79

Goods transport, airlift and sealift.Lola Sheppard. Mason White. MANY NORTHS, Spatial practice in a polar territory. New York: Actar Publishers. 2017. 


\section{NTRODUCTION}

This thesis is about drawing. It is not about a specific architectural proposal, but rather a drawn investigation to find spatial qualities born out of local conditions in an extreme environment. The drawing methods and techniques in this work are a response to the environment; the socio-economic conditions, cultural practices and natural landscape of the North.

This thesis began by examining the environment of lqaluit, Nunavut. Located on Baffin Island, Iqaluit is geographically isolated from the rest of Canada. There is no road to lqaluit, you fly in, or arrive by boat during the warmest weeks of the year when the pack ice dissipates. The average daily temperature in winter is $-32 \mathrm{C}$ and drops even lower with wind chill. Home to approximately 8000 , lqaluit is located at the western point of Frobisher Bay. $50 \%$ of its population are Inuit. Like many other Inuit communities, suicide rates are increasing among young adults. Increasing rates of suicide among youth in the Canadian Arctic is the biggest health problem of the North. While suicide rates are driven by a large variety of factors, it is clear there is a need for targeted intervention to improve the socio-emotional health of young people in Inuit communities. ${ }^{1}$

The built environment is governed by codes, conventions and practices that protect public health and welfare. These codes, conventions and practices have been generated in response to environments south of the Arctic and do not address the socio-economic conditions, cultural practices and natural landscape of lqaluit. Beginning with the assumption that known architectural conventions do not adequately address the Canadian Arctic environment, this thesis developed speculative methods of drawing that respond to the environment of this place. 
These drawings are not meant to be read as plans, sections or details, but as spatial speculations and as the beginning of an approach to architectural drawing for the North. The title of this thesis, Lifeline, refers to this new method of drawing that is sensitive in its response to the socio-economic conditions, cultural practices and natural landscape of lqaluit.
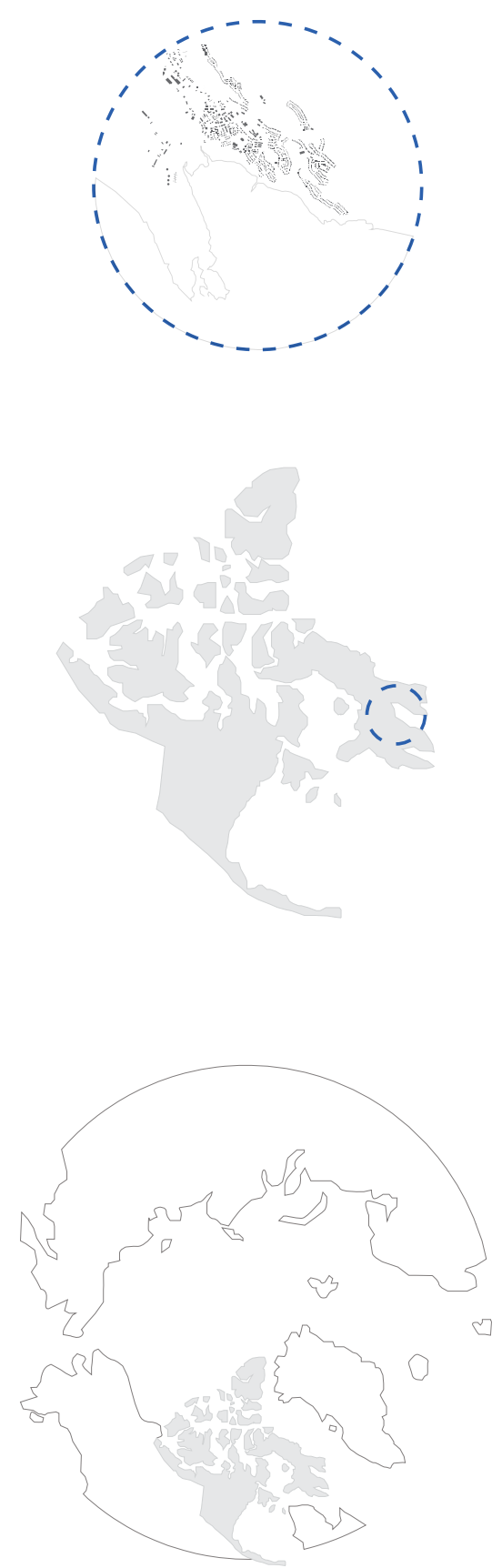


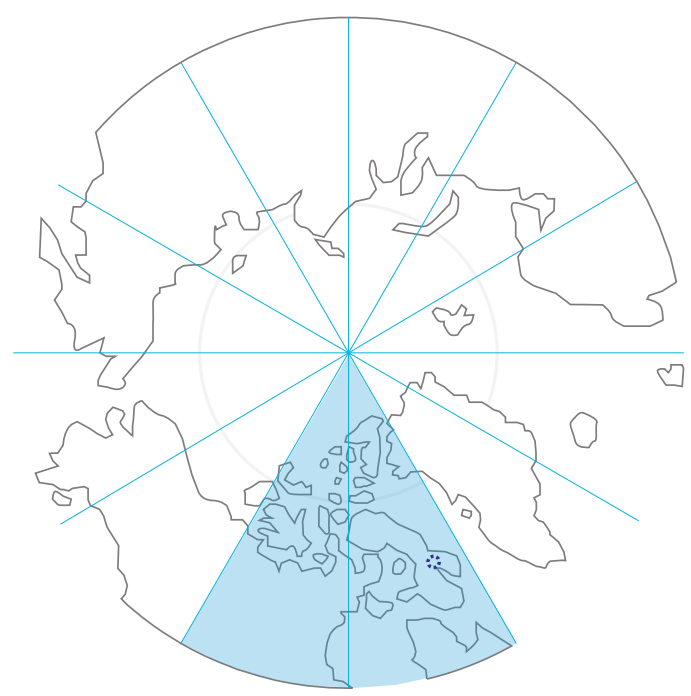

Arctic Map - Nunavut

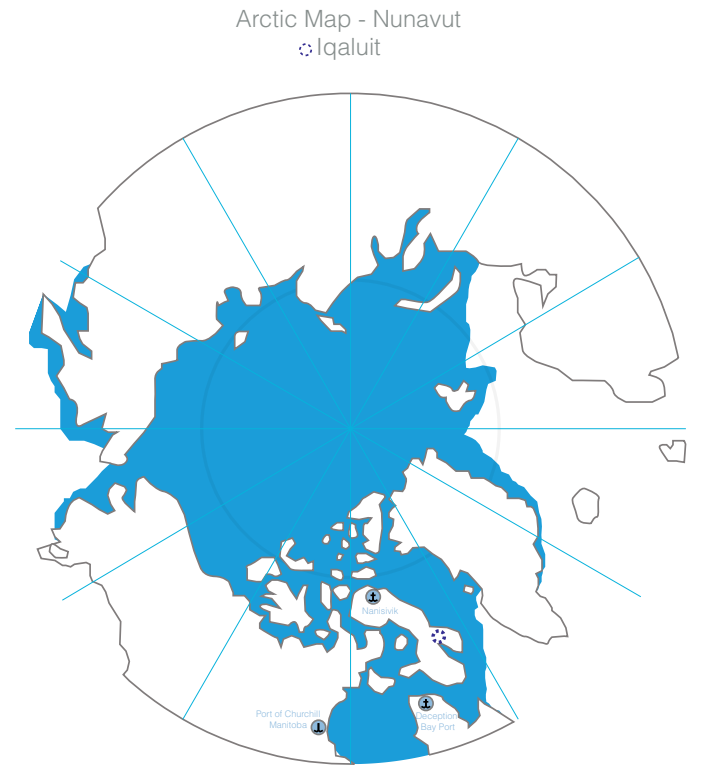

Arctic Maximum Ice Extent

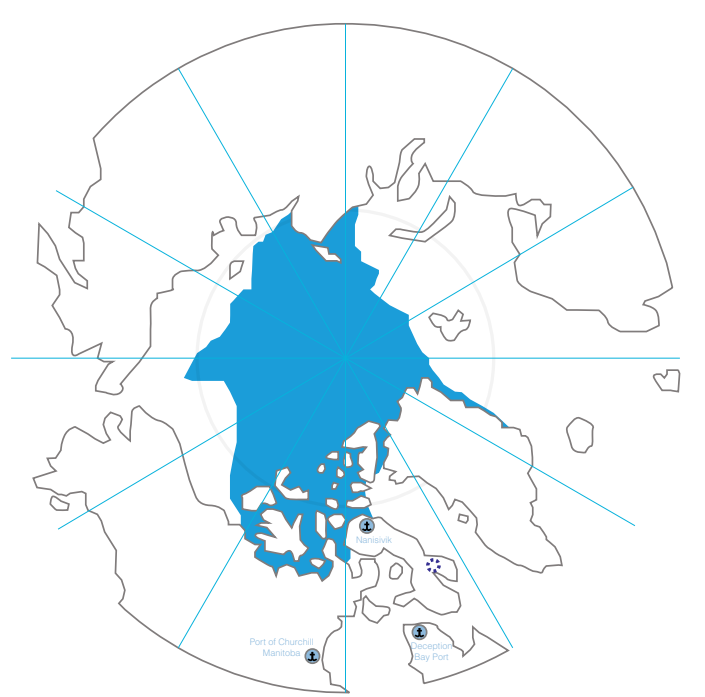

Arctic Minimum Ice Extent 

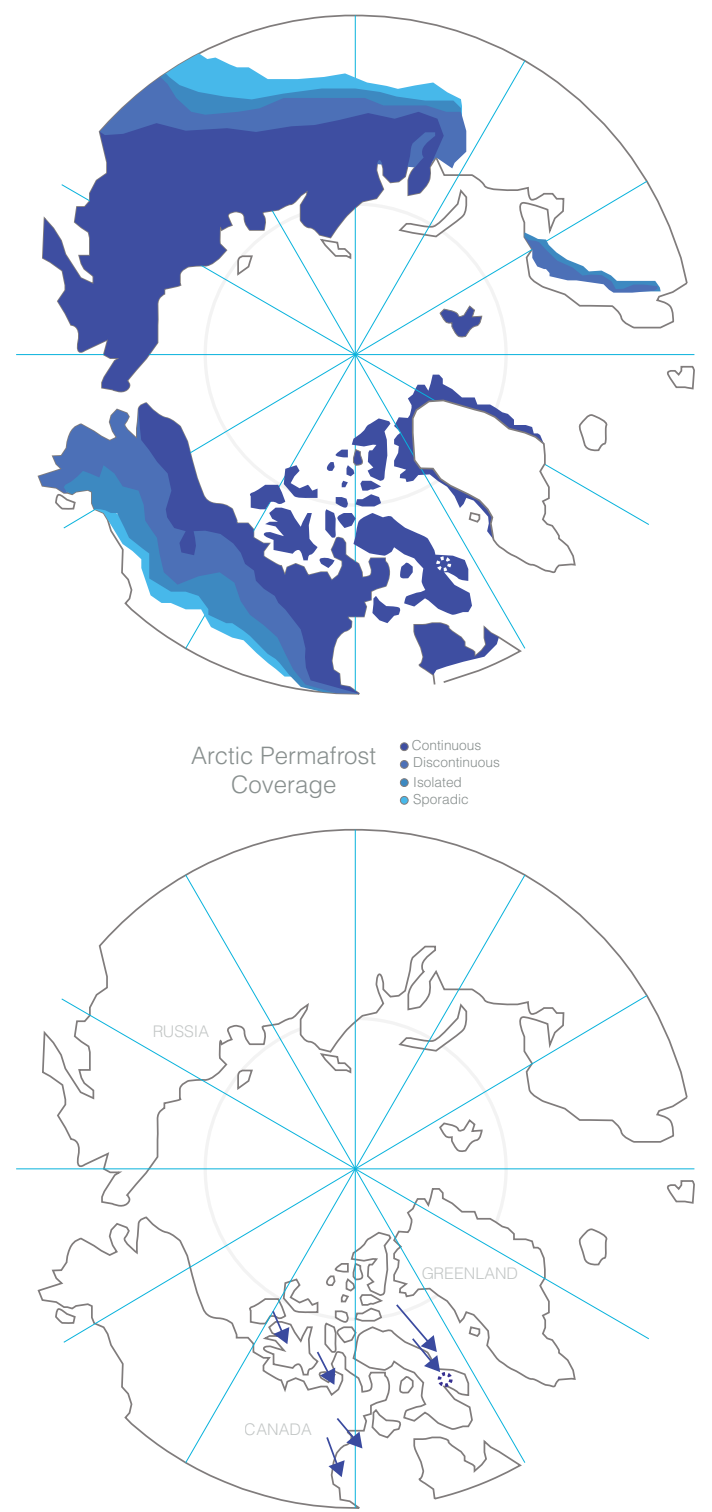

Wind Direction - Nunavut

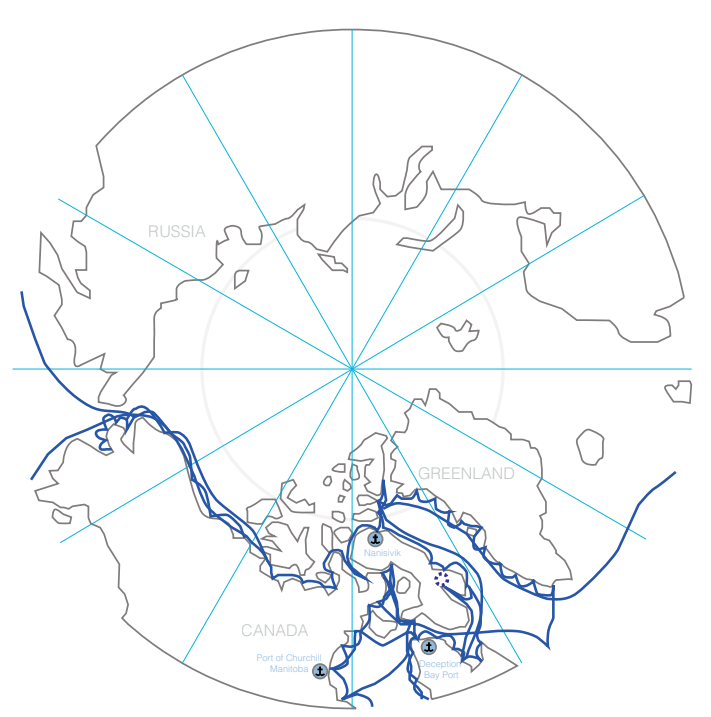

Arctic Shipping Route 


\section{OBJECTIVE OF THESIS}

This thesis aims to use the environment of lqaluit to generate speculative drawings as a form a research. The work addresses three areas:

1-Socio-economic conditions: Existing architecture in Iqaluit, often typologies imported from the south, produce social isolation and this isolation spurns a variety of public health concerns. Social isolation is a contributing factor to substance abuse, sexual abuse, mental illness and suicide.

As new arctic shipping routes open through the Canadian Archipelago, it is likely that there will be an increase in Western influence and a coinciding increase in social isolation among Inuit people. This thesis seeks to develop new methods of drawing space that sensitive to the environment of lqaluit as a prompt to find new approaches to architectural drawing that are sensitive to the socio-economic conditions of the North. 


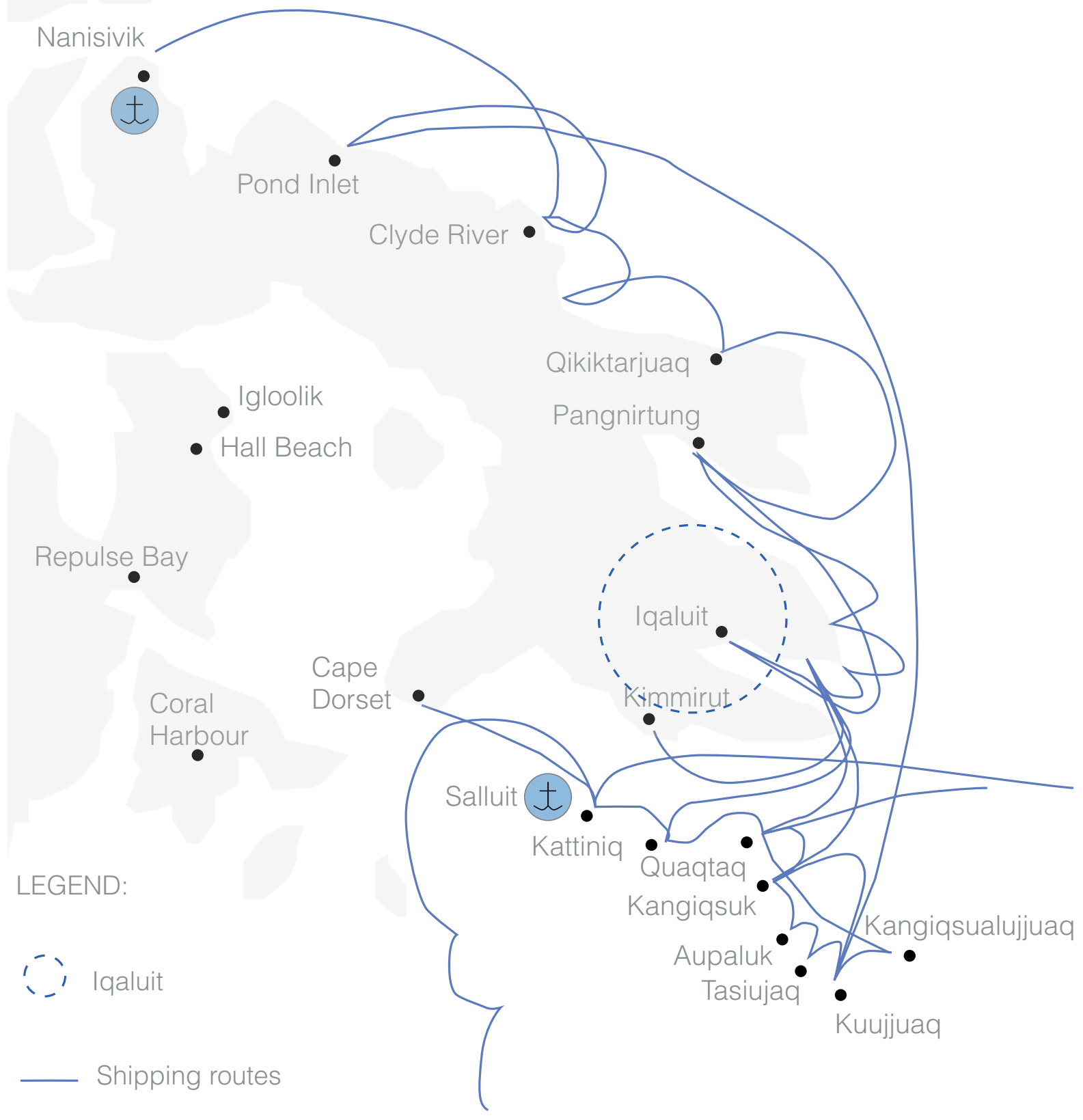

(t) Deep-sea port

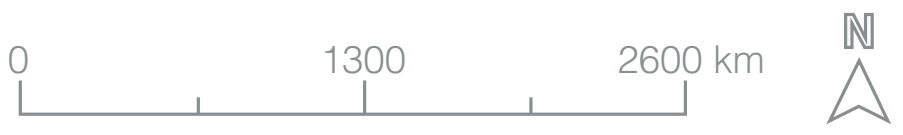


City Plan, Iqaluit [2010]

Pop: 6,699 [2011]

Settled: 1942

City status: 2001

Area: $52,50 \mathrm{~km} 2$

Density: $127.6 / \mathrm{km} 2$

Dwellings: 2,930 
Nanisivik

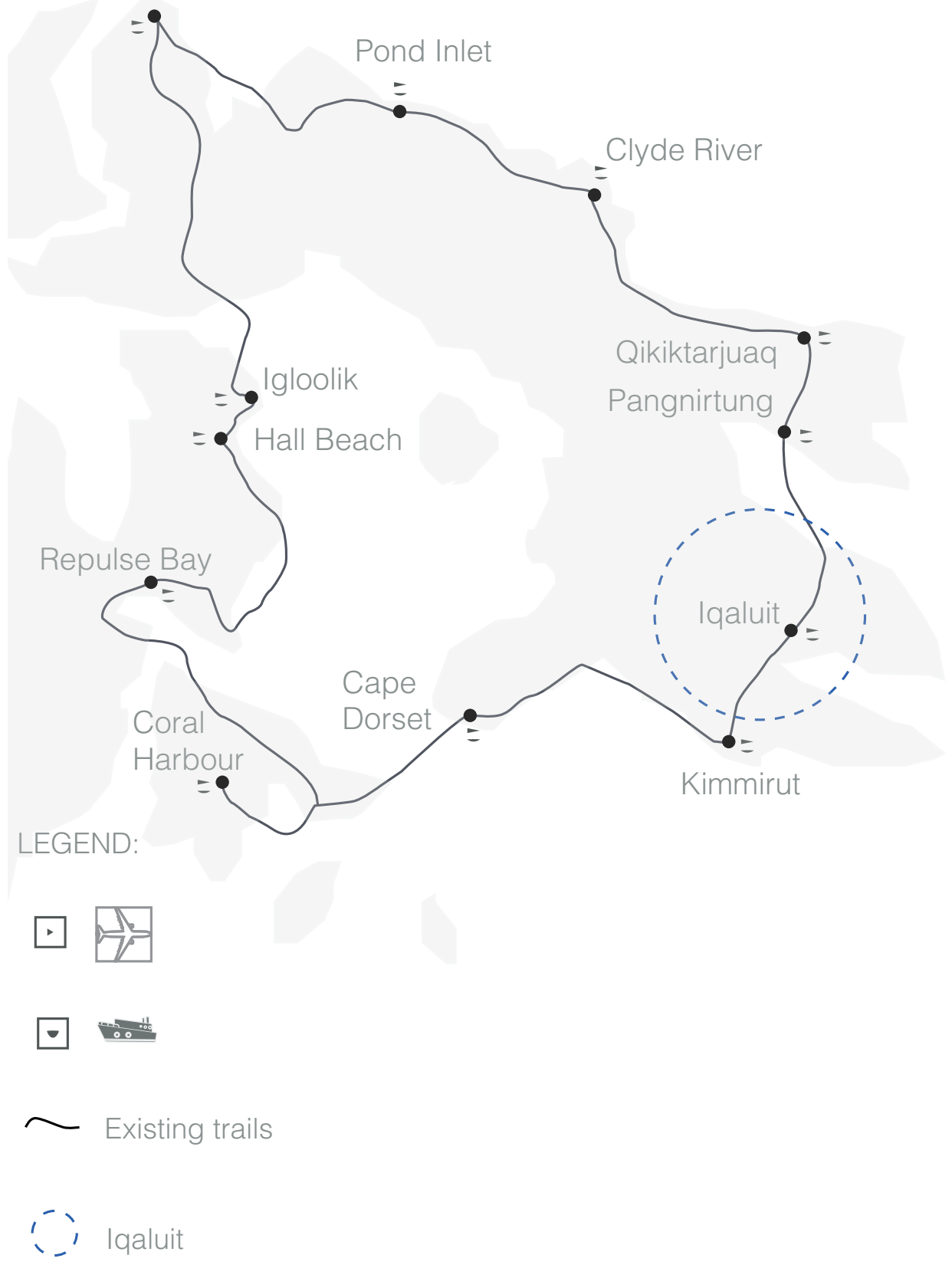


2 - Cultural Practices: Conventional strategies, such as separating residential areas from commercial areas at an urban scale or even the design of a kitchen at the scale of a home, are out of sync with traditional Inuit practices. Hunting, slaughtering, and food sharing are an essential part of Inuit social structure. These practices require temporary, seasonal structures. In other words, appropriate architectural strategies in Inuit communities are dynamic. Drawing from traditional Inuit cultural, this thesis aims to develop new methods of architectural drawing that are dynamic in nature and can both document and express the dynamism of traditional Inuit cultural practices. 
3 - Natural landscape: Standard methods of mapping, documenting and measuring the natural landscape do not account for the extreme conditions of the North. Large annual deviation in solar cycles, extreme weather conditions, and large tidal flows make this landscape difficult to measure. The Inuit measure distance not in miles, but in "sleeps." One measures distance by calculating how may stops for rest are necessary to get from one destination to another. This method of measuring the landscape includes the impact that weather, topography, luck, skills, size of the group, etc. would have on the travel time. Learning from Inuit techniques for mapping and measuring the landscape, this thesis aims to develop new methods of architectural drawing that are perception-based and able to account for extremes of the natural landscape in the North. ${ }^{3}$ 


\section{SITE ANALYSIS}

This thesis began in a manner similar to many other architectural projects; with a site analysis addressing physical, environmental, economic considerations. Using the quantifiable information gleaned from this site analysis, I began proposing architectural programs and programmatic relationships on the site. The forms, spaces and architectures explored in response to this site analysis were drawn from pre-conceived notions and fundamentally felt out of place. I was practicing architecture from outside the perspective of the North. The analysis and proposals contained in appendix A represent the research that led to a shift in focus of the thesis toward the development of a drawing method more appropriately suited to this site. 


\section{DRAWING STRATEGY}

\section{CONCEPT:}

Lifeline uses drawing as a form a research. Architectural drawing has the capacity to position ideas in productive relationships to one another and the three objectives of this thesis are intersected through a process of drawing that is sensitive to socio-economic conditions, cultural practices and the natural landscape of the North. Specific issues of suicide rates, dynamic cultural practices and perception of the natural landscape are addressed through the development of speculative, spatial drawings.

1 - Suicide: The death rate by suicide in Inuit populations under the age of 25 in Nunavut has increased more than six-fold over the previous three decades. Across all age groups, suicide rates in Labrador and Nunavut are nearly seven times the Canadian average. ${ }^{4}$

Marc Stevenson, Principal of All Nations Services, outlined that Inuit suicide is directly related to regional economic transformation. The ruin of the seal skin market in the 1980 s played a significant role in rising Inuit suicide rates. Such economic factors when combined with social isolation in communities like lqaluit, have created a public health crisis. ${ }^{5}$ 


\section{2 - Dynamism: Dynamic cultural practices, historically}

connected to hunting and migration, are fundamental to Inuit social life. A successful hunt would have been celebrated with drumming and dancing. Drumming was banned for a time by the Canadian government and the traditional Inuit dance celebrations were suppressed. The loss of these traditions, among others, is directly connected to the increase in suicide rates. Traditional Inuit dance can be considered as a form of therapy for suicide prevention. Dance is a physical activity, stimulating circulation of the blood, oxygenation of the organs, and repairing the heart and the joints. Dance is also a cultural activity, connecting participants and viewers to historical traditions and ways of life. 


\begin{abstract}
3 - perception: The natural landscape has historically been perceived and measured by the Inuit in relative terms. This symbiotic relationship between viewer and environment is a defining theme of traditional Inuit dances.
\end{abstract}


Iqaluit is a real place; the actions described are real actions. Drawings attempt to explore and deliver interactions between man,objectm, hidden forces of the environment and their engagement with space and the occurrence of events.

These set of drawings hang between reality and fantasy of deconstructivism which is a movement of postmodern architecture in $1980 \mathrm{~s}$. "Deconstructivism gives the impression of the fragmentation of the constructed building. It is characterized by an absence of harmony, continuity, or symmetry." 6

Besides fragmentation, Deconstructivism creates non-rectilinear shapes and its finished visual appearance is characterized by unpredictability. ${ }^{7}$ 

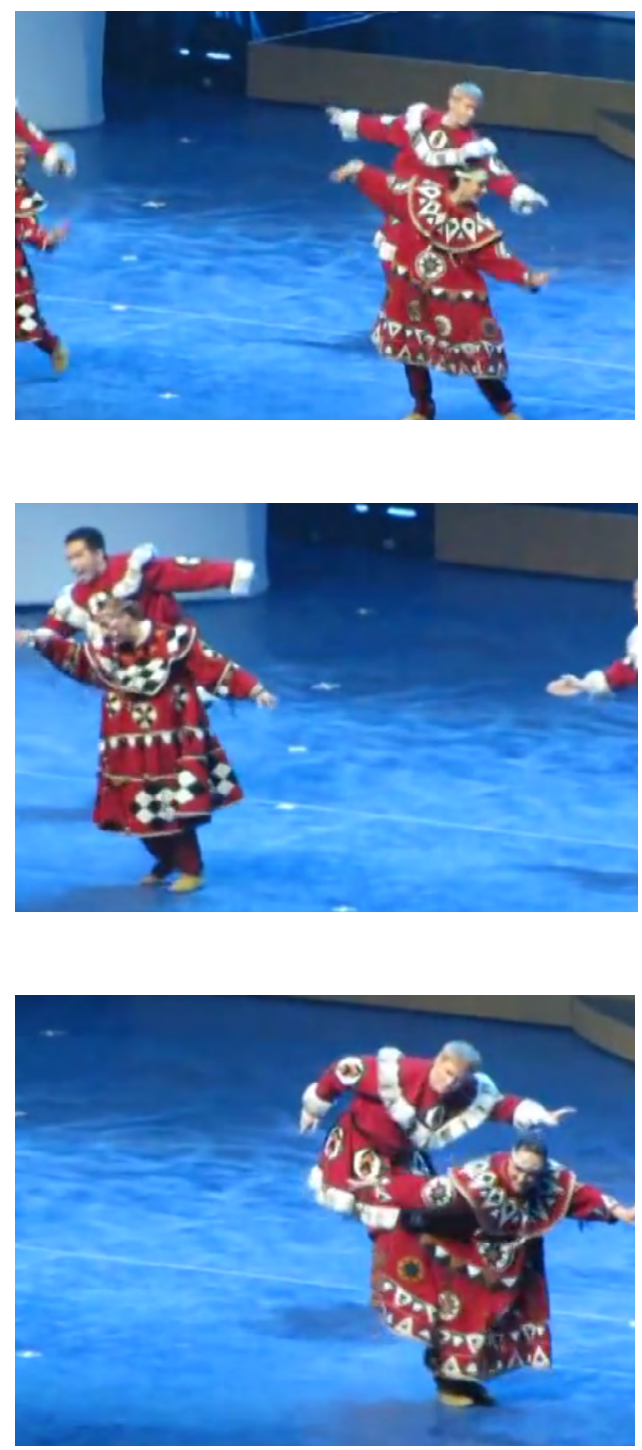

Inuit Traditional Drance 


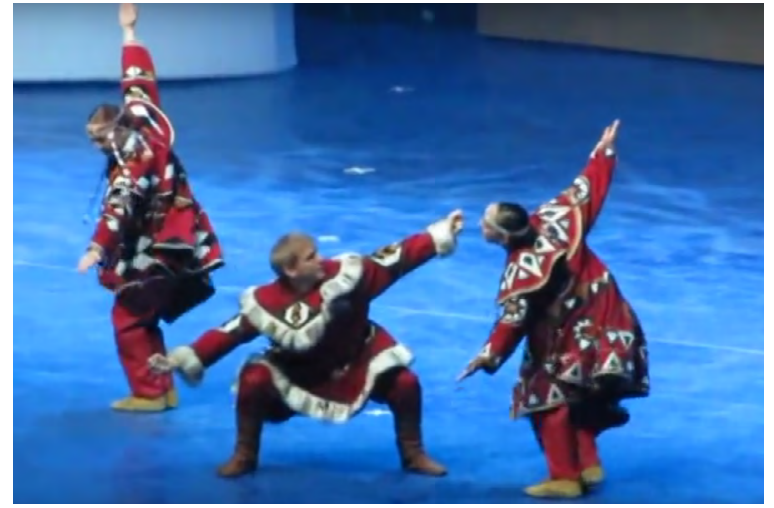

( A )

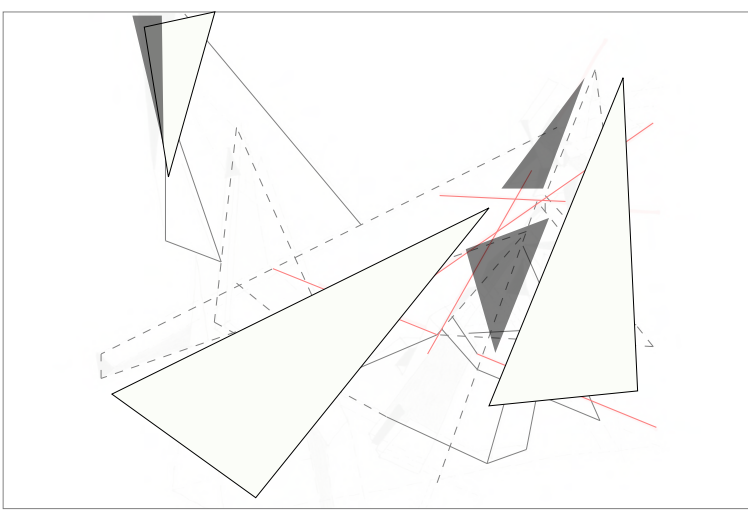

( B )

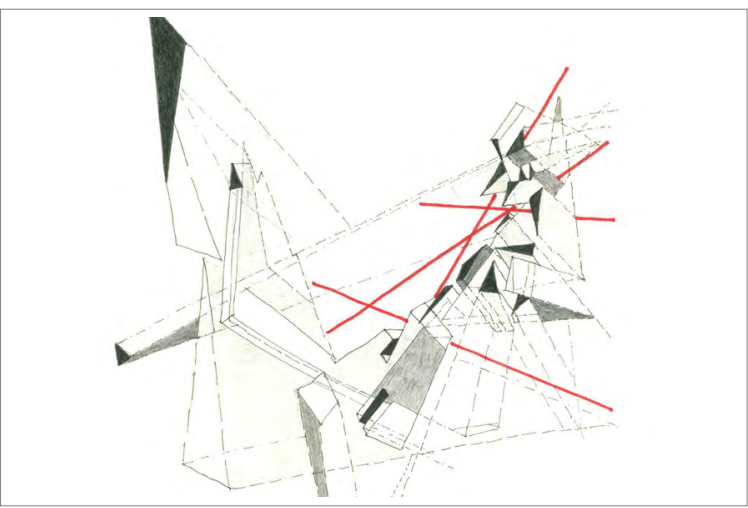

( C )

The drawings always

presuppose a reality already

in existence(A), a reality

waiting to be

desconstructed(B), and

eventually transformed(C). 
A series of preliminary drawings were developed by translating traditional Inuit dancing into a series of lines, shapes, color and movements. Motion is expressed through the incorporation of multiple perspectives and observed choreography in the dancing.

The work was developed iteratively, first by embedding the observed rules of the dancing into the drawings and then by building new drawings out of these systems of rules. The drawings create a system for architectural speculation that draws on the specific nature of this place. These experimental drawings allow for new interpretations of spatial possibility and reveal hidden forces through the exploration of technique.

The drawings are then translated back into rules for generating new drawings. 


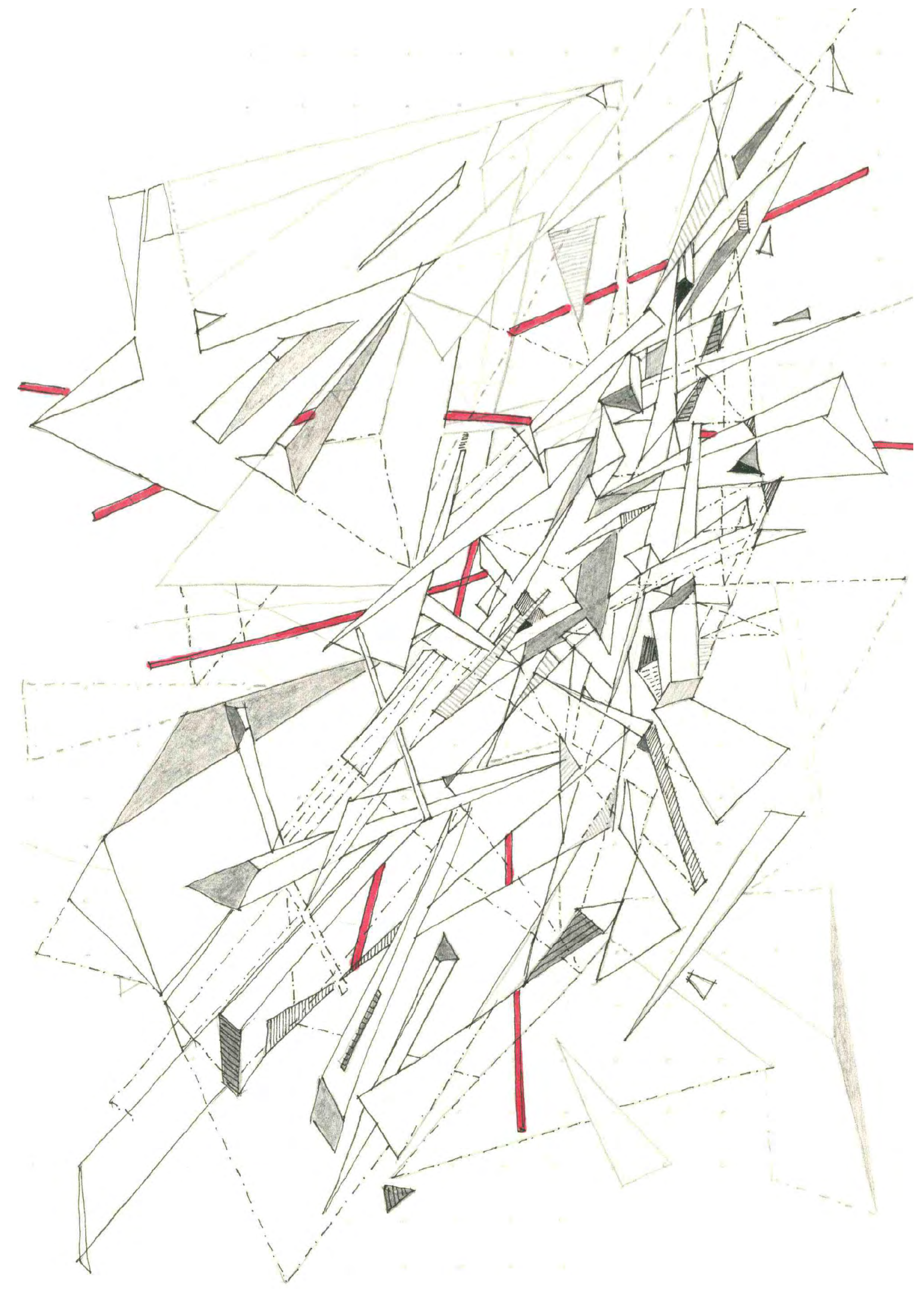




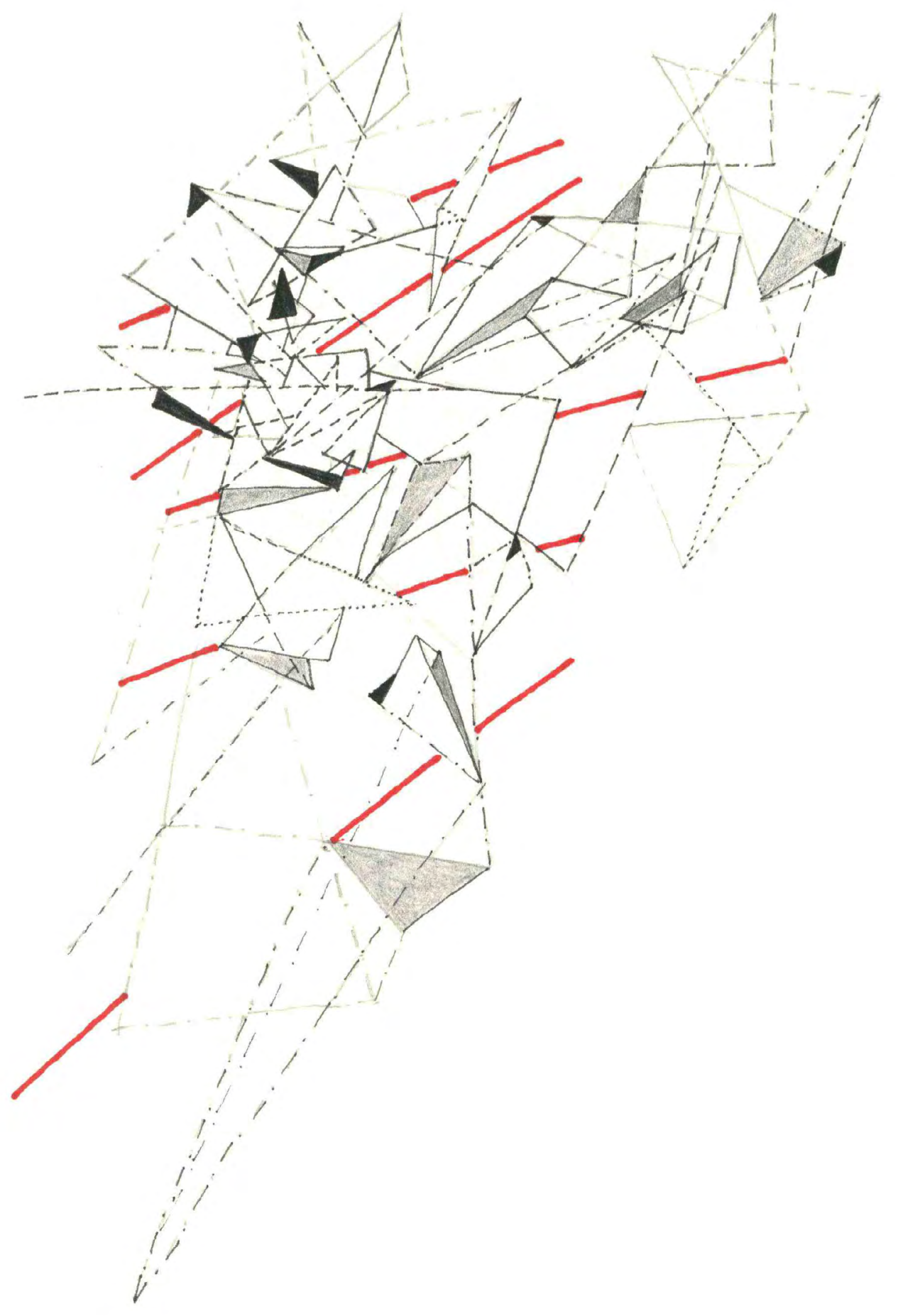




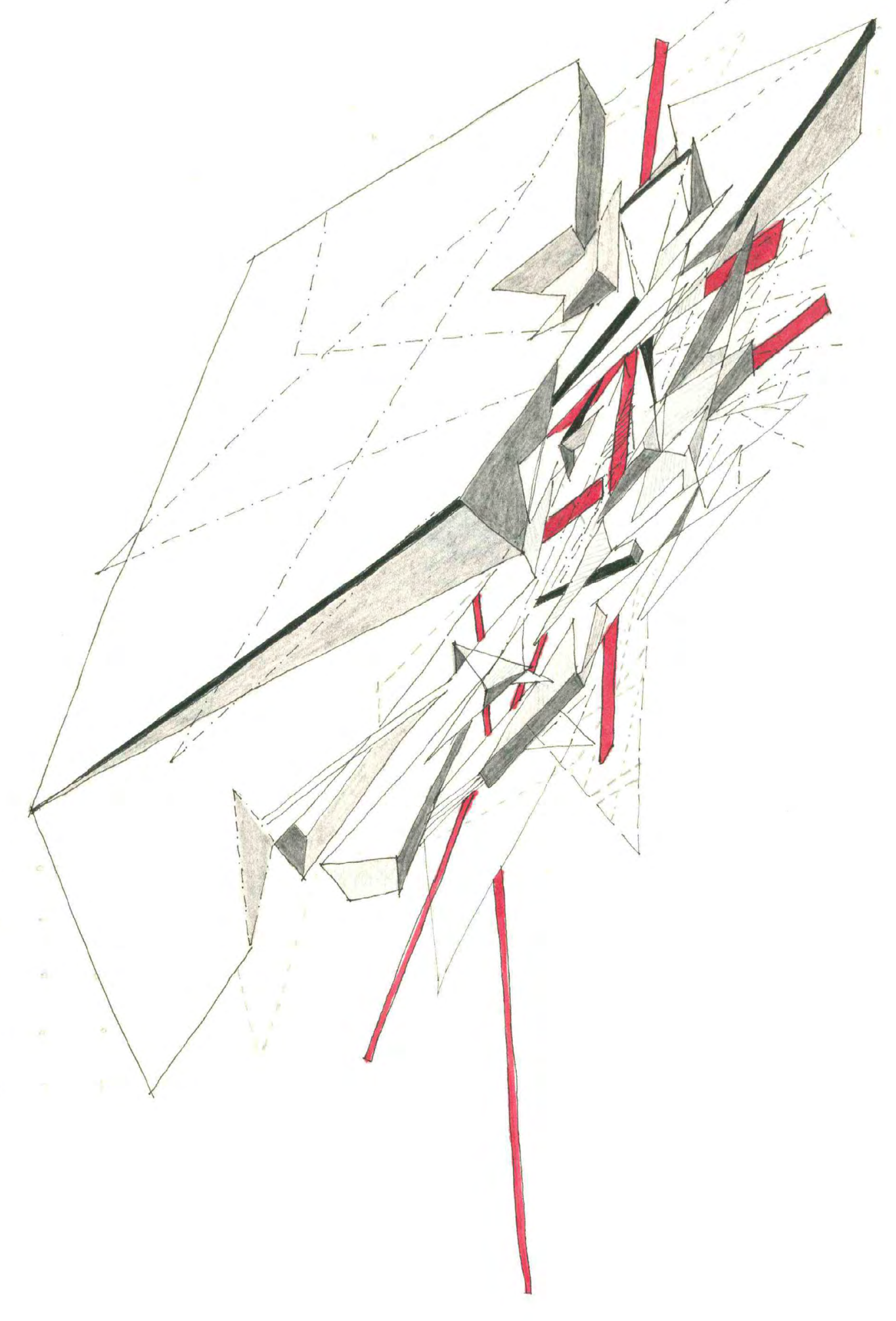




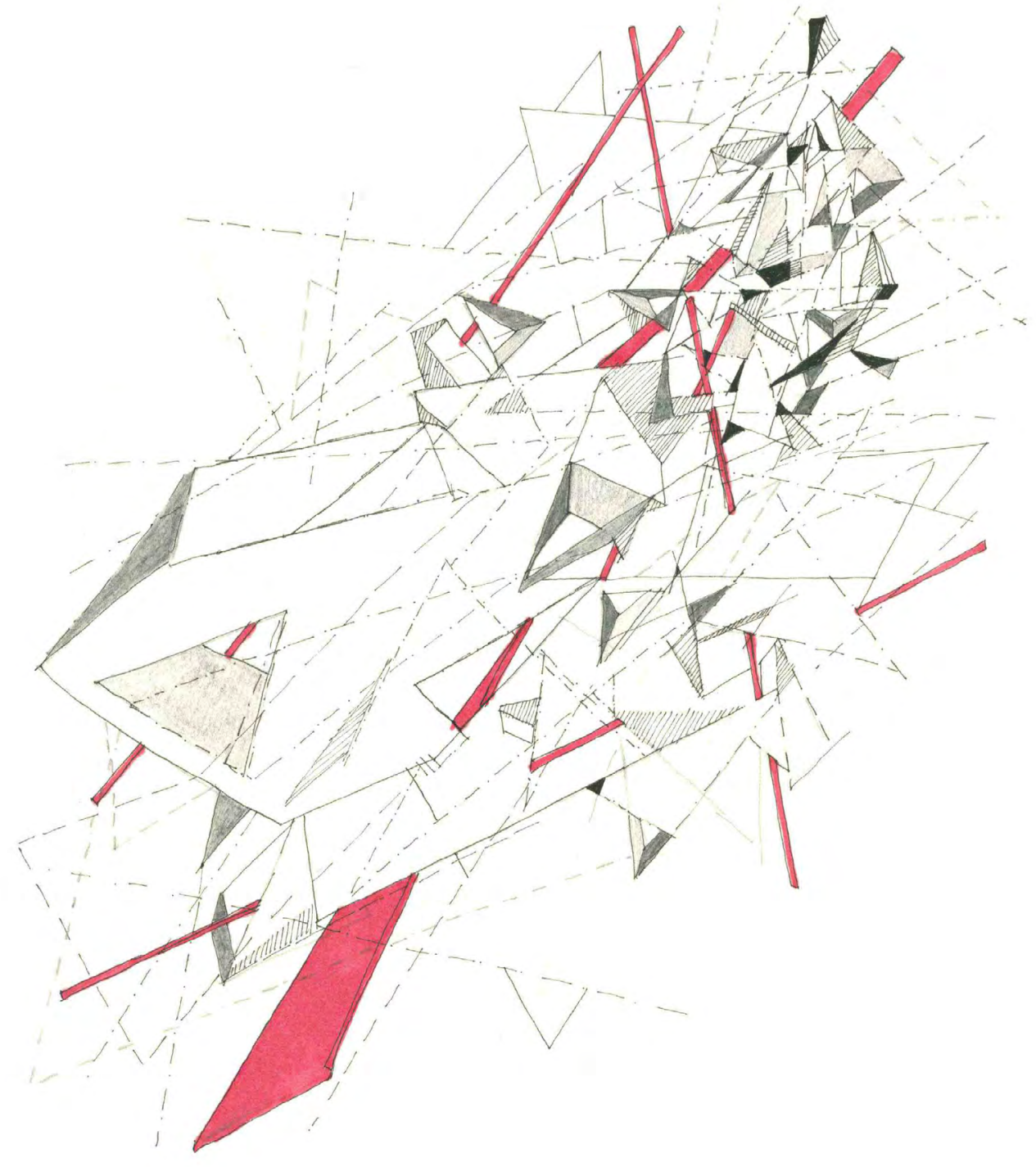




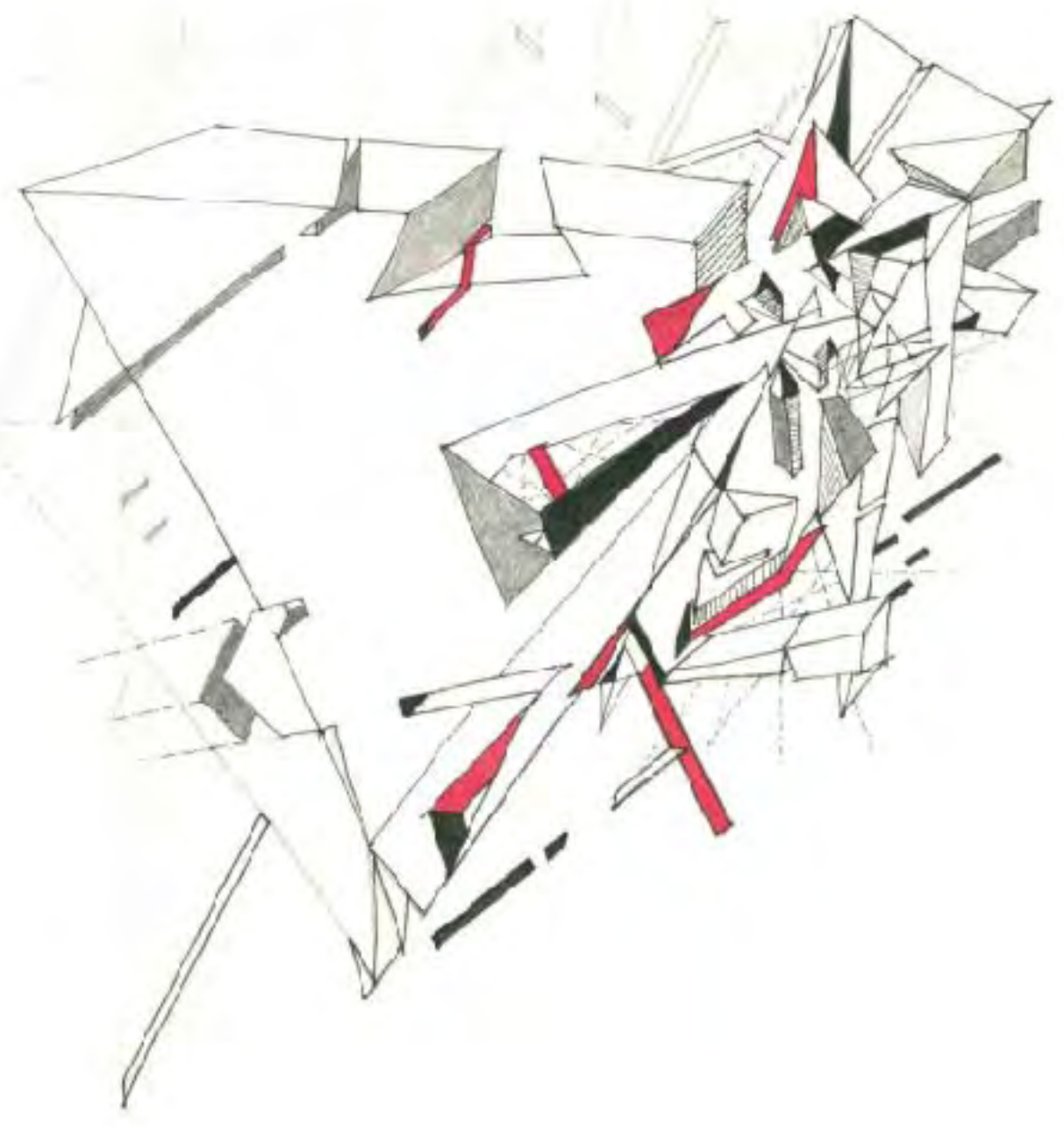




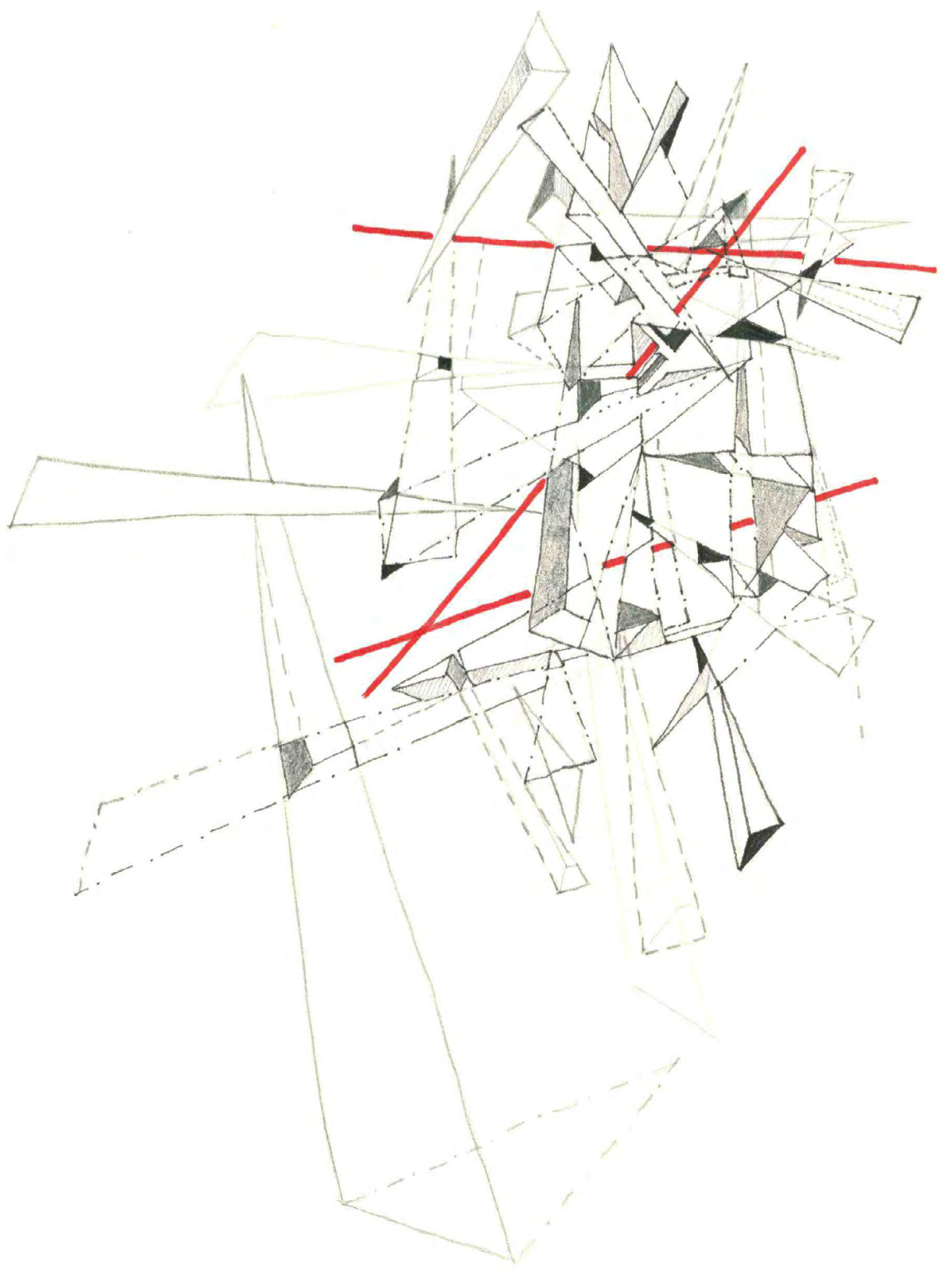




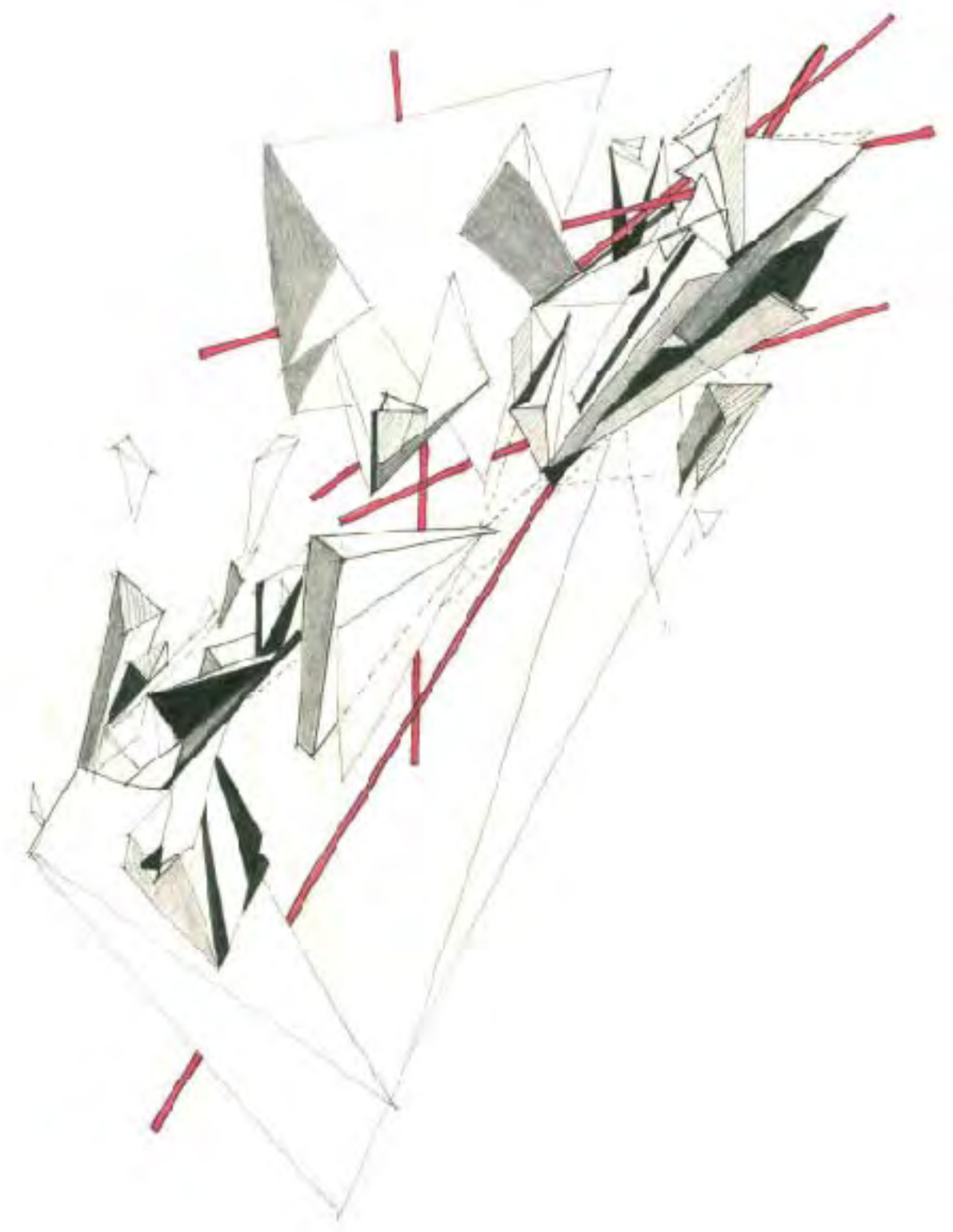




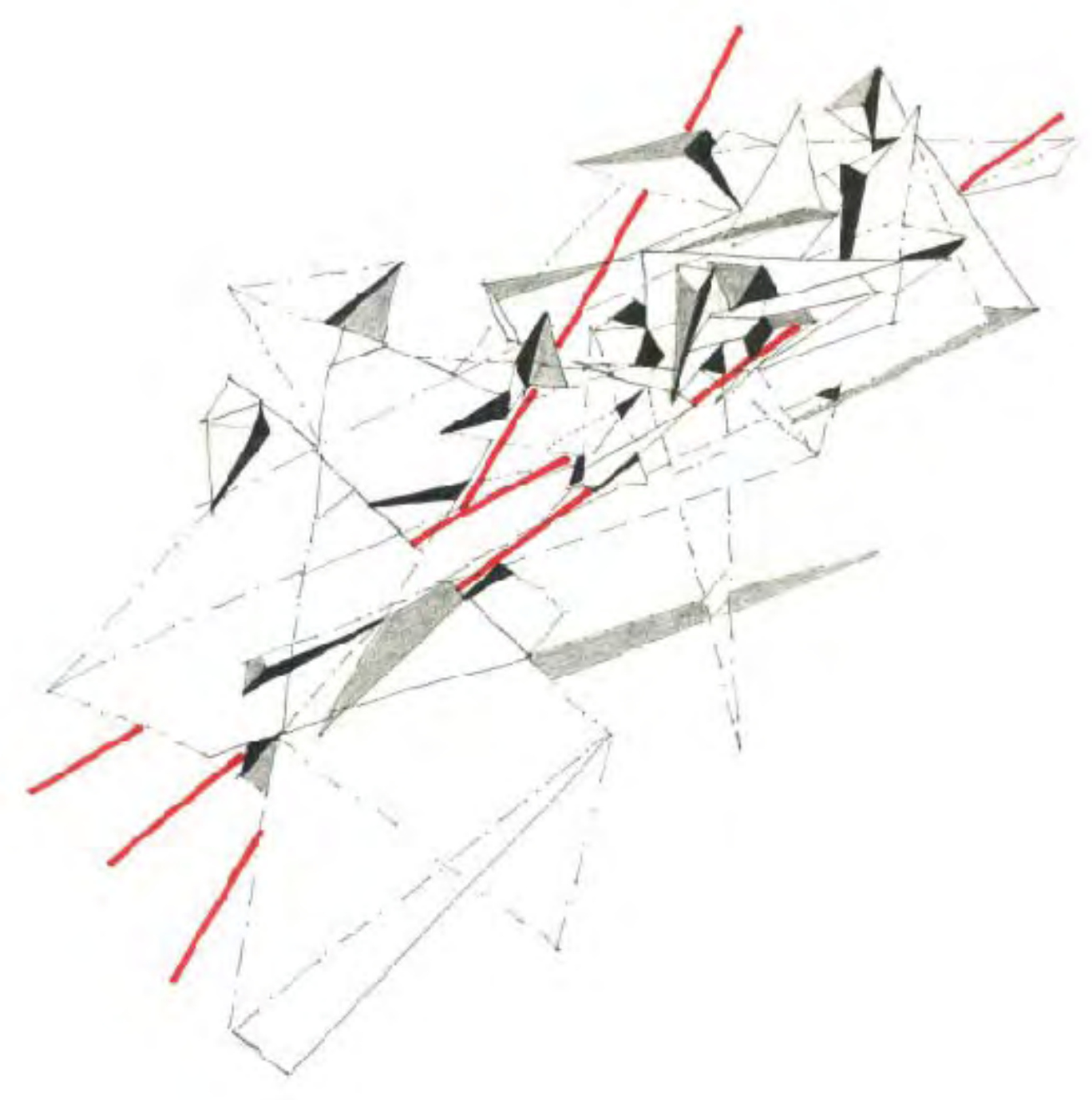




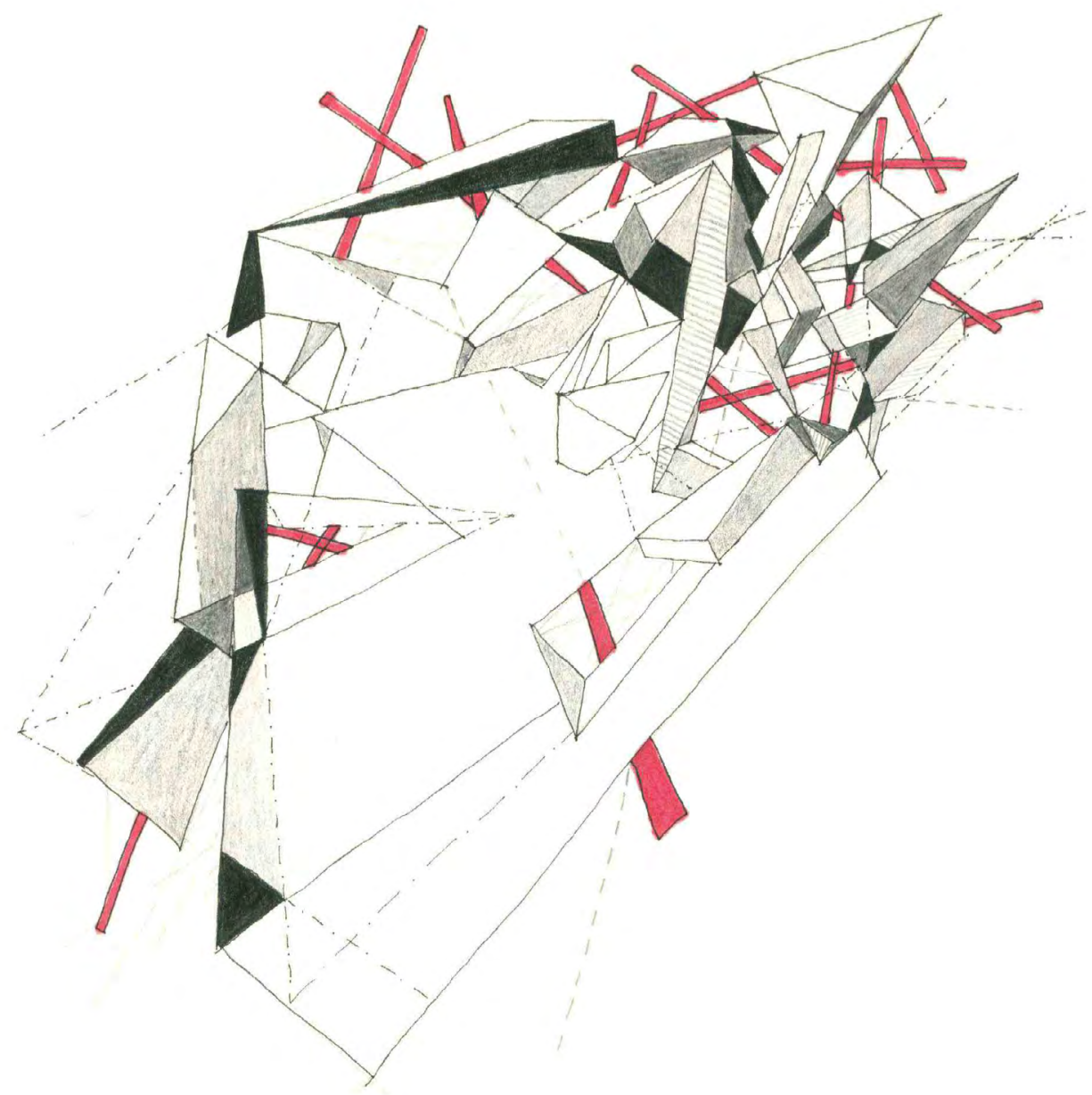




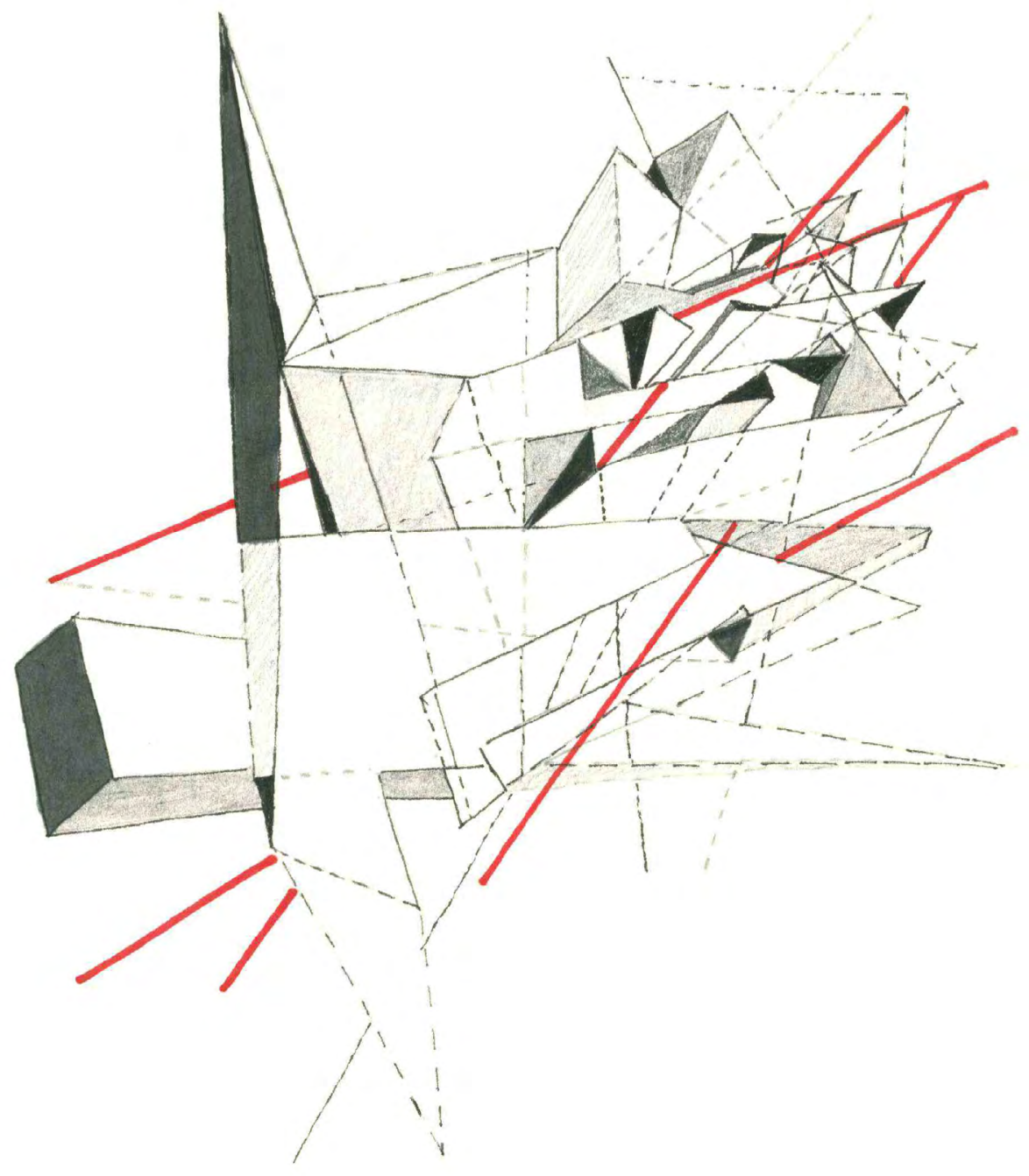




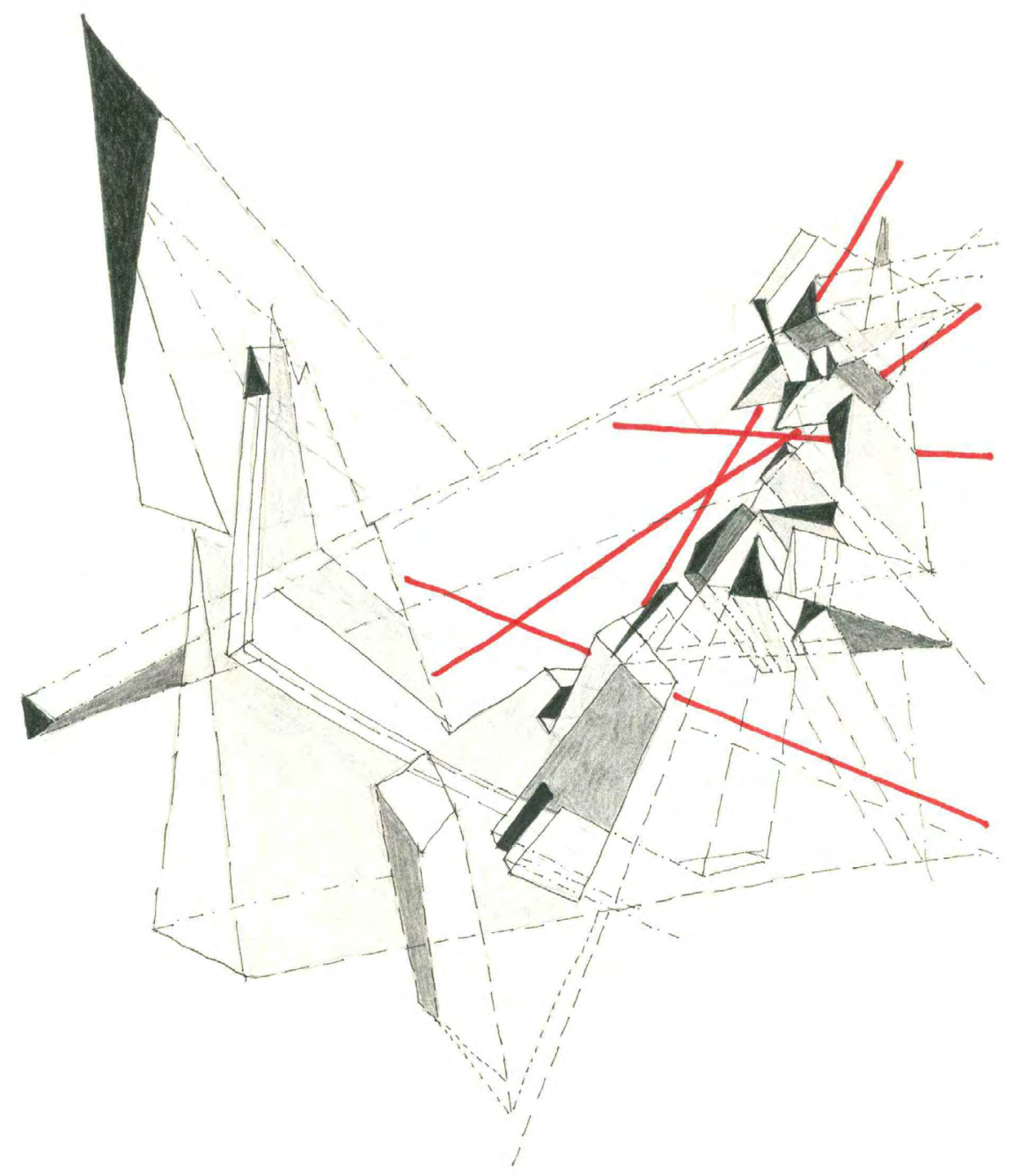




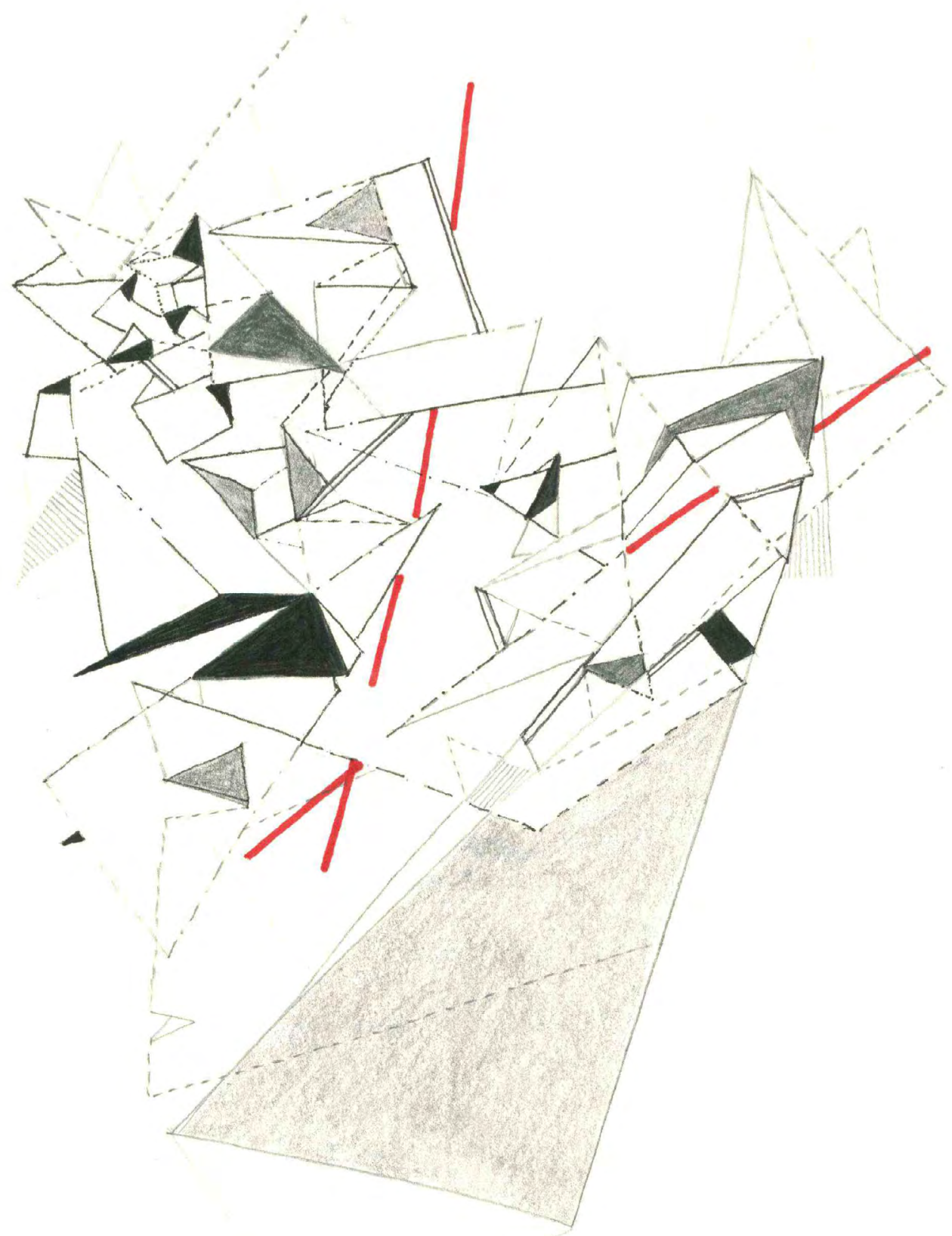




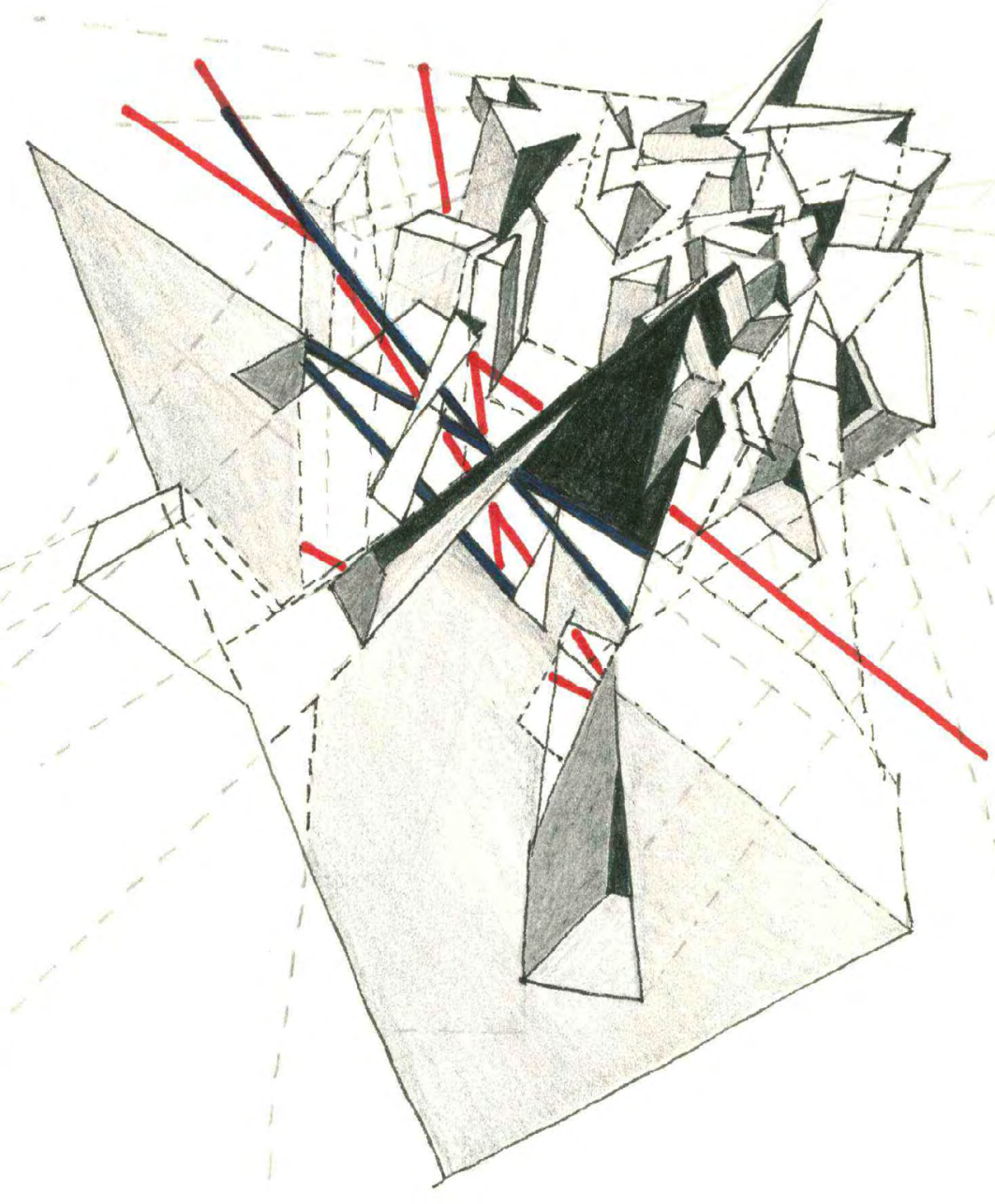




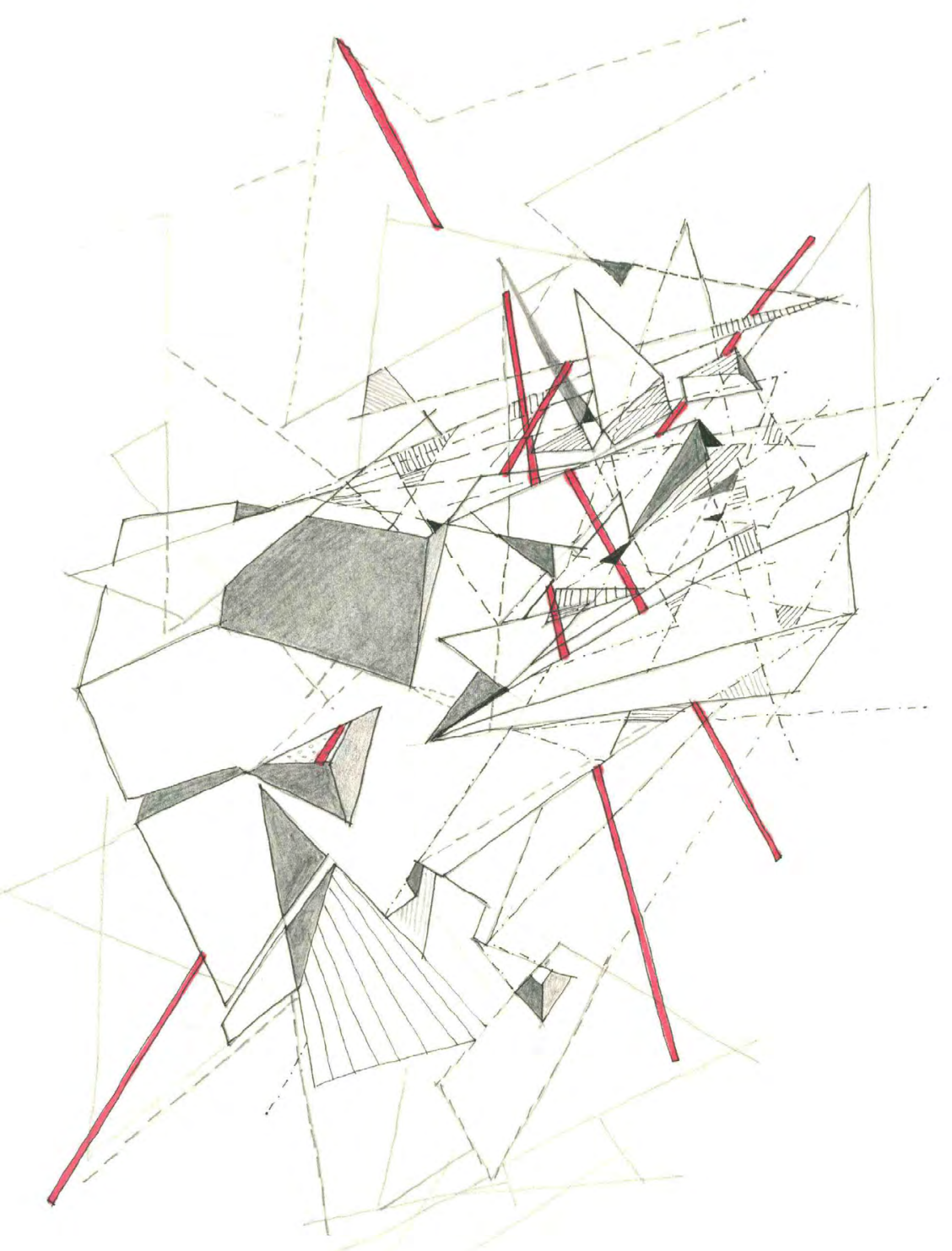




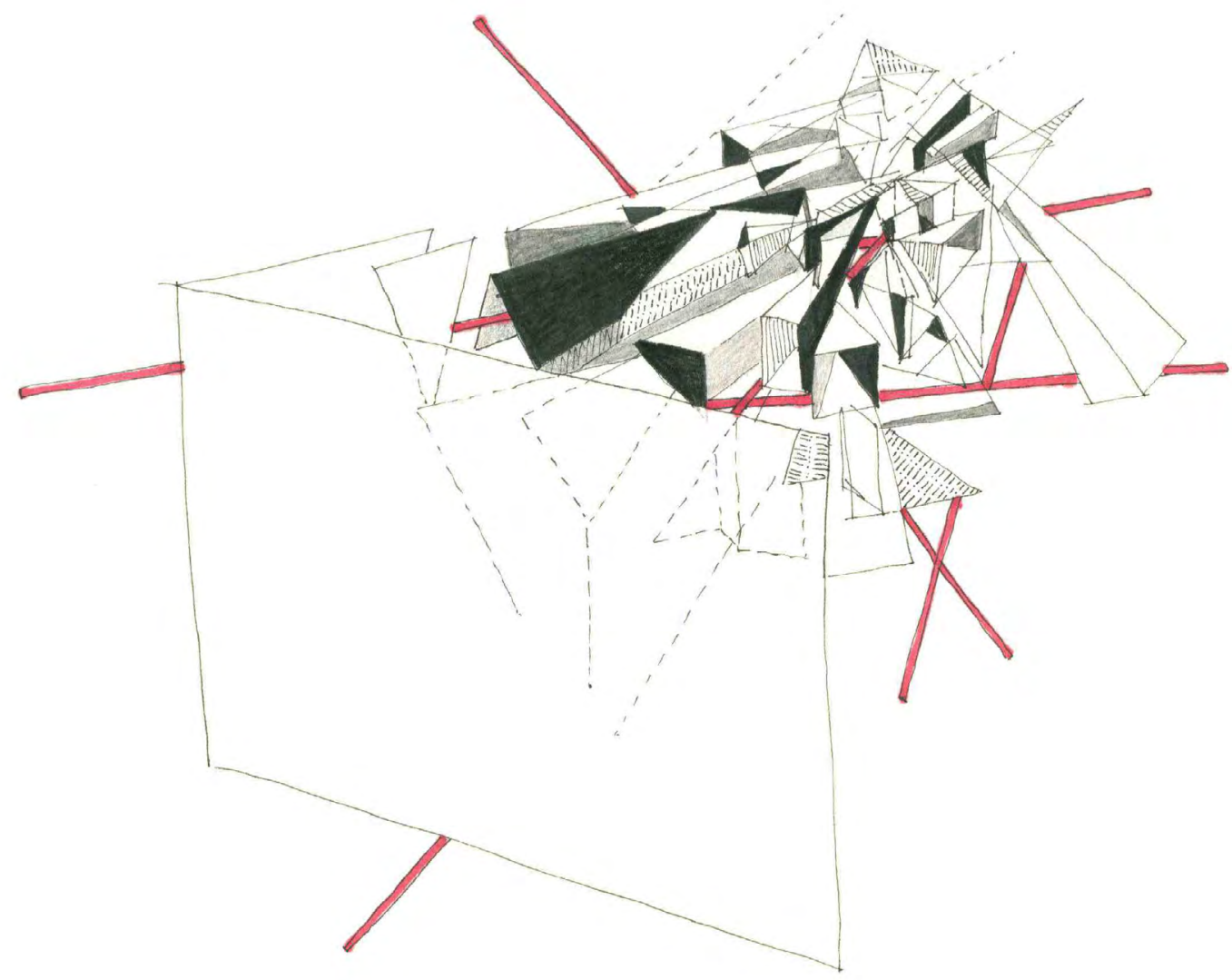


The work was further developed into a new series of drawings using four rules, each informed by the context of this place.

1 - Complexity, not simplicity. Seasonality shapes every aspect of Inuit life including housing. Inuit winter house and summer house are different. They live in the igloo and bone houses called Qarmaq during the winter. Igloo are made of snow blocks, and are quick to build. Seasonal change force them to make a transition from Igloo to the skin tents during the summer. Today temporary dwelling have been replaced by cabin that serve as shelters for hunting. The location of winter settlement varied annually. Based on research by anthropologist Milton Freeman, existing of the source of food was the primary reason for sellecting a winter settlement. ${ }^{8}$

Multiple geometries, interpenetrating spaces, multi-perspectival spaces, overlapping and and the complex relationship between the context and the proposed spaces contribute to the complexity in drawings.

2 - It if full of tension. The Arctic region is basically a frozen ocean. The condition may be considered too tough for most humans. These forms consist of elements which dialogue in tension with each other: the geometrical fragment, in contrast with the linear transitional ways-red lines-reflecting the paradoxical nature of tension in the context. 


\begin{abstract}
3 - spontaneity. "As Inuit say today is today and tomorrow is tomorrow and people can not predict future." 9 This means that Inuit can not make firm plans for their travel path in order to catch food and they have to learn to accept and be adapted to the unpredictability of the future and change. Focusing on the importance of the process and moment in the COMPOSITION set of drawings is based on the inability of the human to predict the future.
\end{abstract}

4 - It is risky. Inuit believe that "Things happen when they happen as they happen" 10 Such as attitude entails living in the moment and acting based on present circumstances. The COMPOSITION set of drawing shows how time-moment-and space are interlinked and if there is no experience of time, the space can not be defined. 


\section{COMPOSITION:}

The freedom of form, belonging to the sphere of feeling, contains a kind of unformed orders which creates

movement. And constantly changing visual scene happens while a dancer is dancing or when viewer is changing his point of view and experience specific moments. A number of deliberately awkard moments will be created which complicate the intersecton of forms as a build space with its human occupation while they are not disconnected from the context. The discordant moments will be created as the viewer changes the visual scene and tries to interpret those scenes as a journey of space.

The dancer and the viewer are both in motion which creates a shifting viewpoint through the drawing. The viewer captures unexpected views of different level by changing the viewpoint and can moves from one to another space. Every translation of space is a degree of freedom with multiple transformative qualities. It seems that multiple projections collapsed into one drawing.

These drawings consist of individual moments which are superimposed. The intention is to emphasis on the importance of the process. 


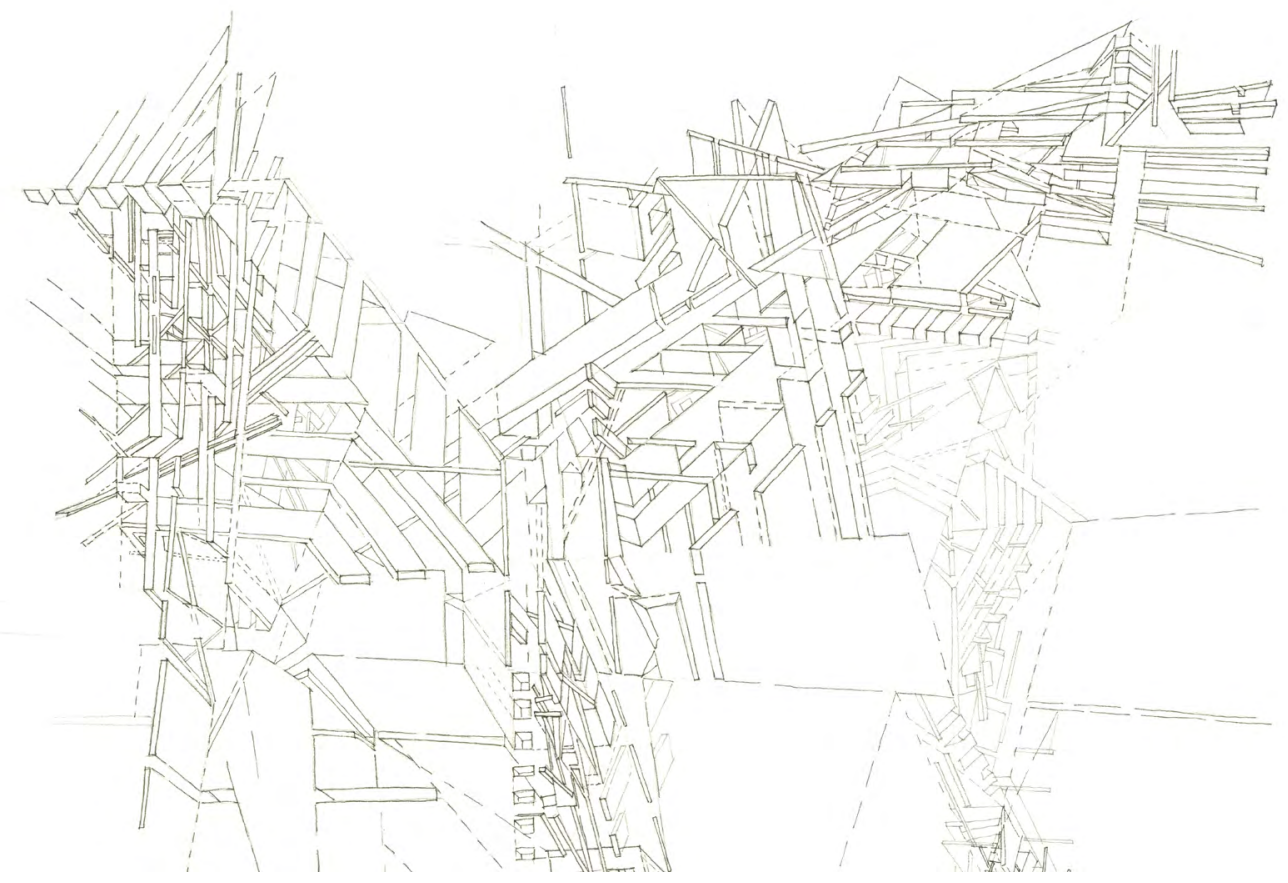


The idea behind presenting a series of process drawing is coming from Inuit concept of time. As they believe that the people can not control over the future, "Inuit tend to emphasize the importance of process. If one is unable to predict what will get done, how things are done becomes important." 11 According to Inuit, time is perceived in terms of durée=duration or moments that flow into one other. Each moment exists individually, but they flow into something else when put together.

The main intention of using such these forms, is to reveal powerful hidden forces of the environment and adapt them to the need of the project. The hidden forces of this landscape are translated in to the language of forms which are taken from the nature.

Inuit believe human do not control the forces of the environment but, they must ally themselves to these forces to keep harmony between different forces and human being. 


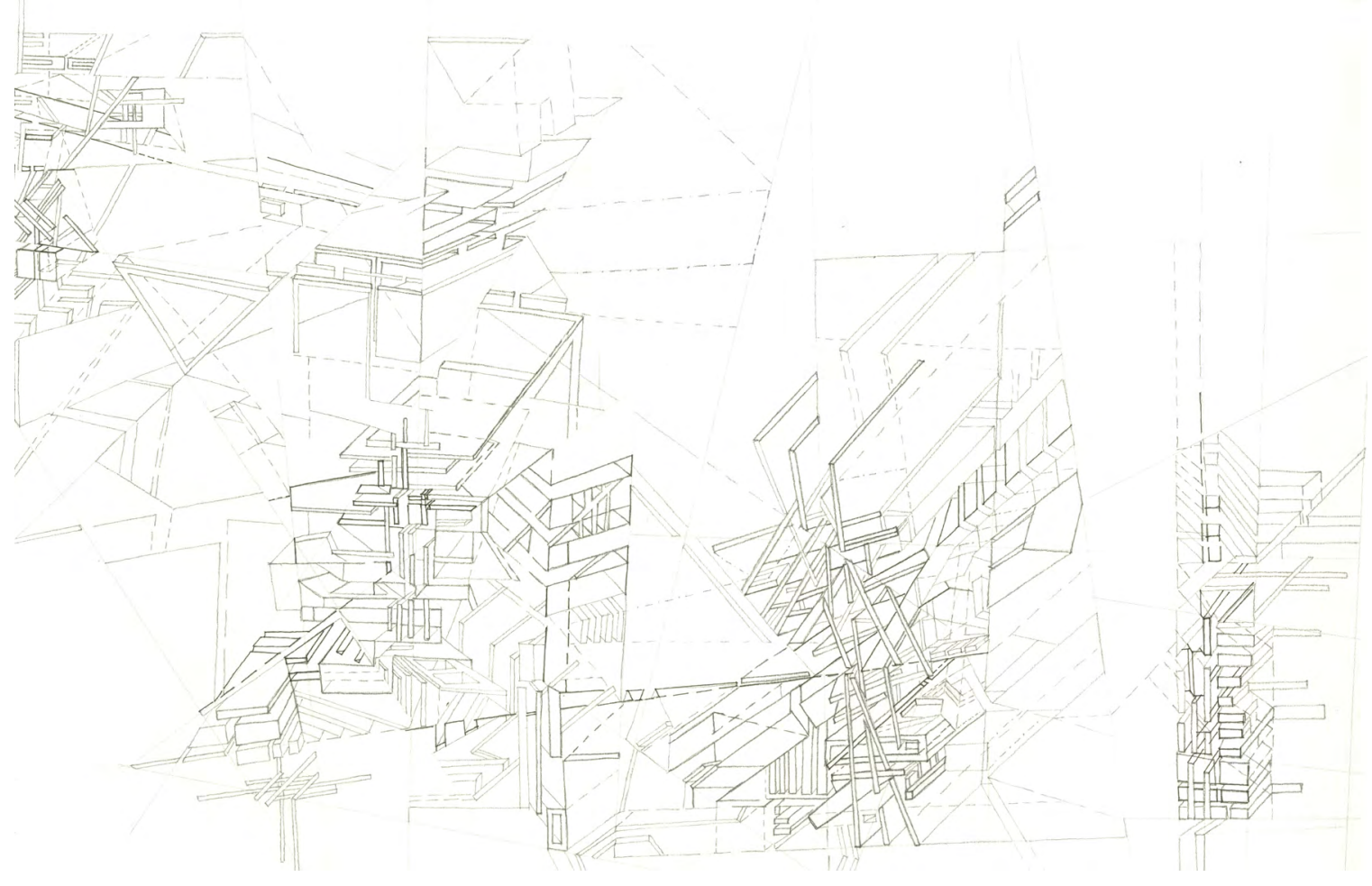


The important thing about the architectural approach to this work is that, architecture is about the action, event and what is happening in spaces while taking into account Northern cultural and climatological sensibilities.

The understanding of these spaces relies on the perception of the space (which allows us to take in, understand and make our conclusion) rather than sensation(information received through the senses). 


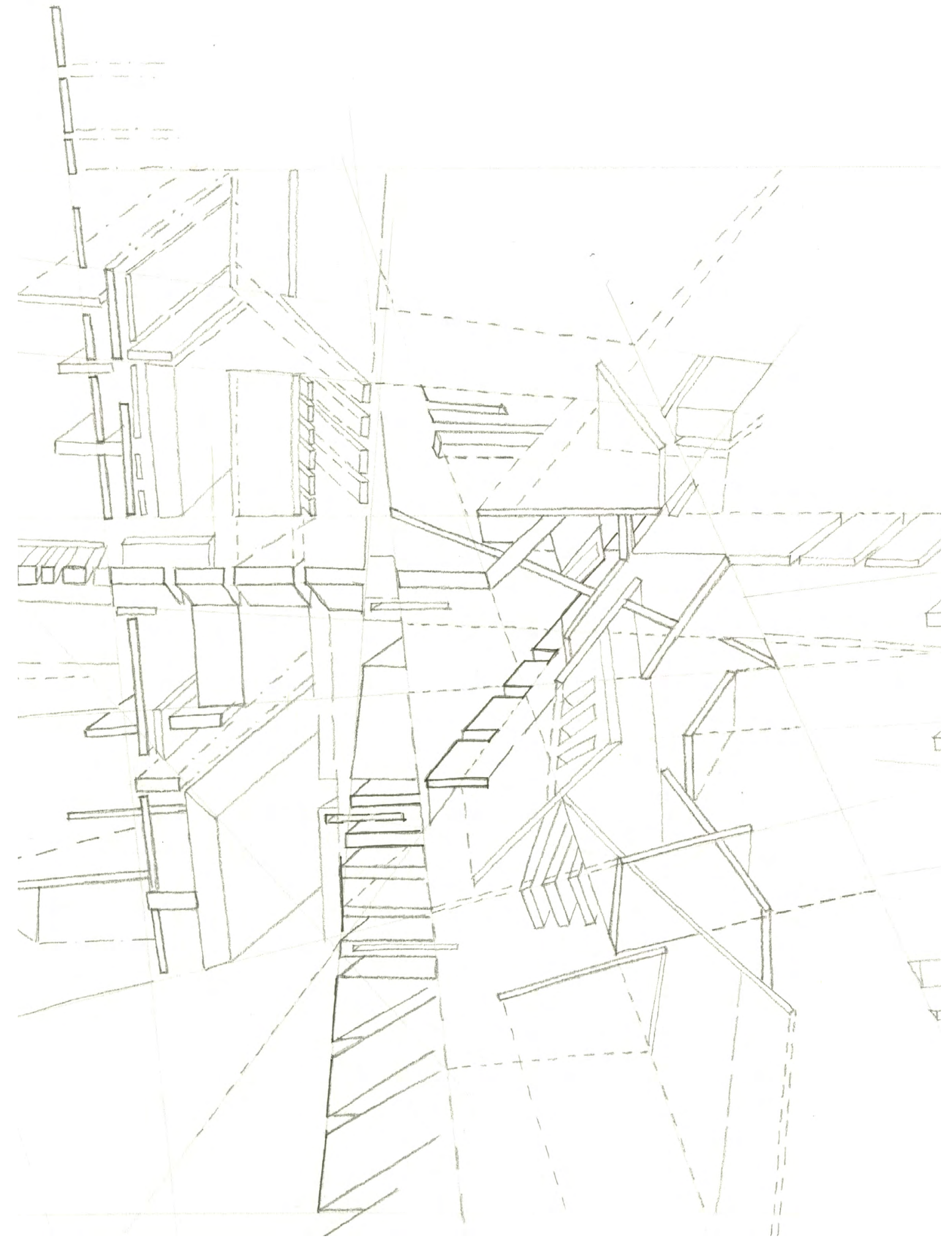




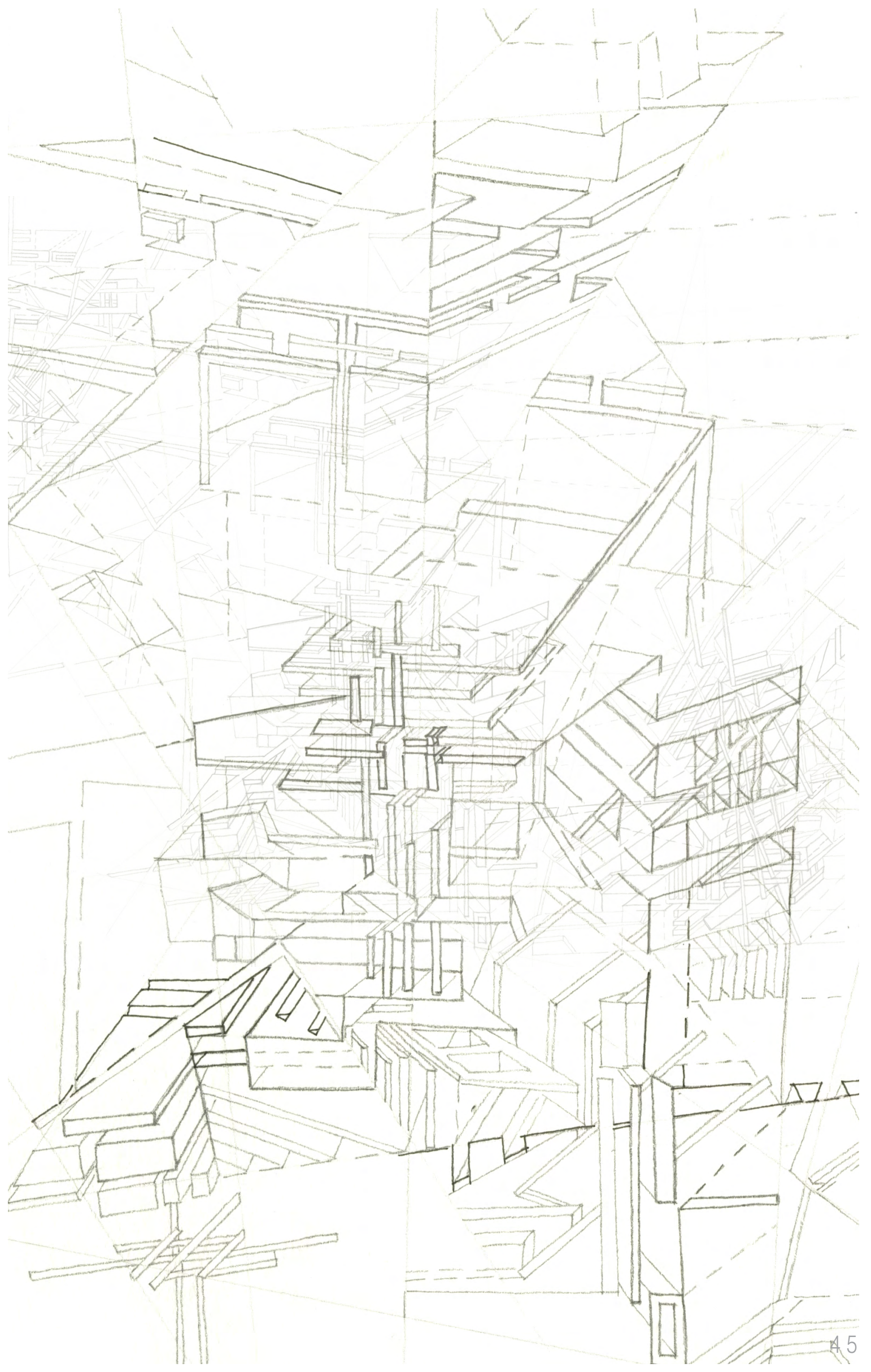




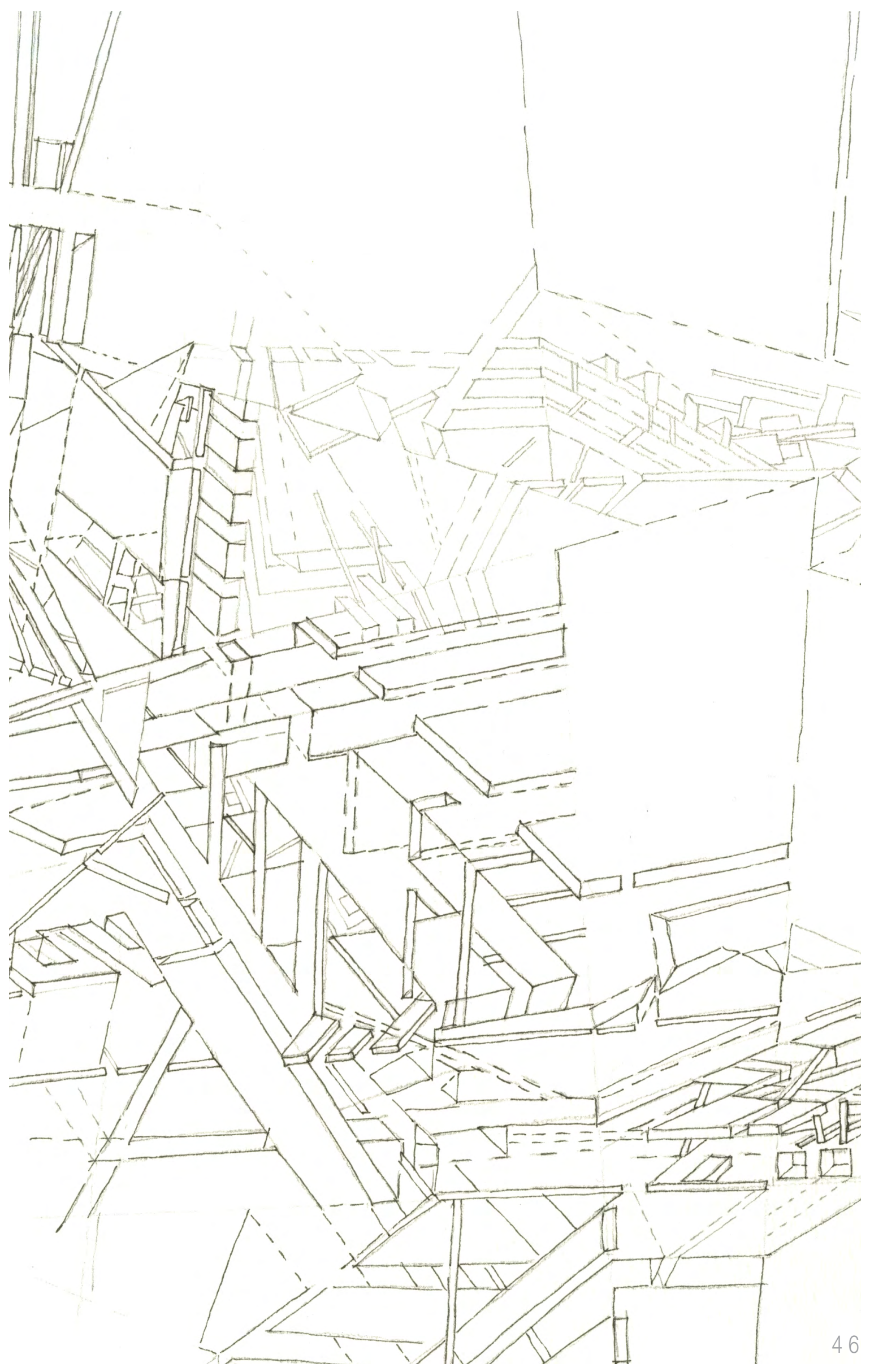




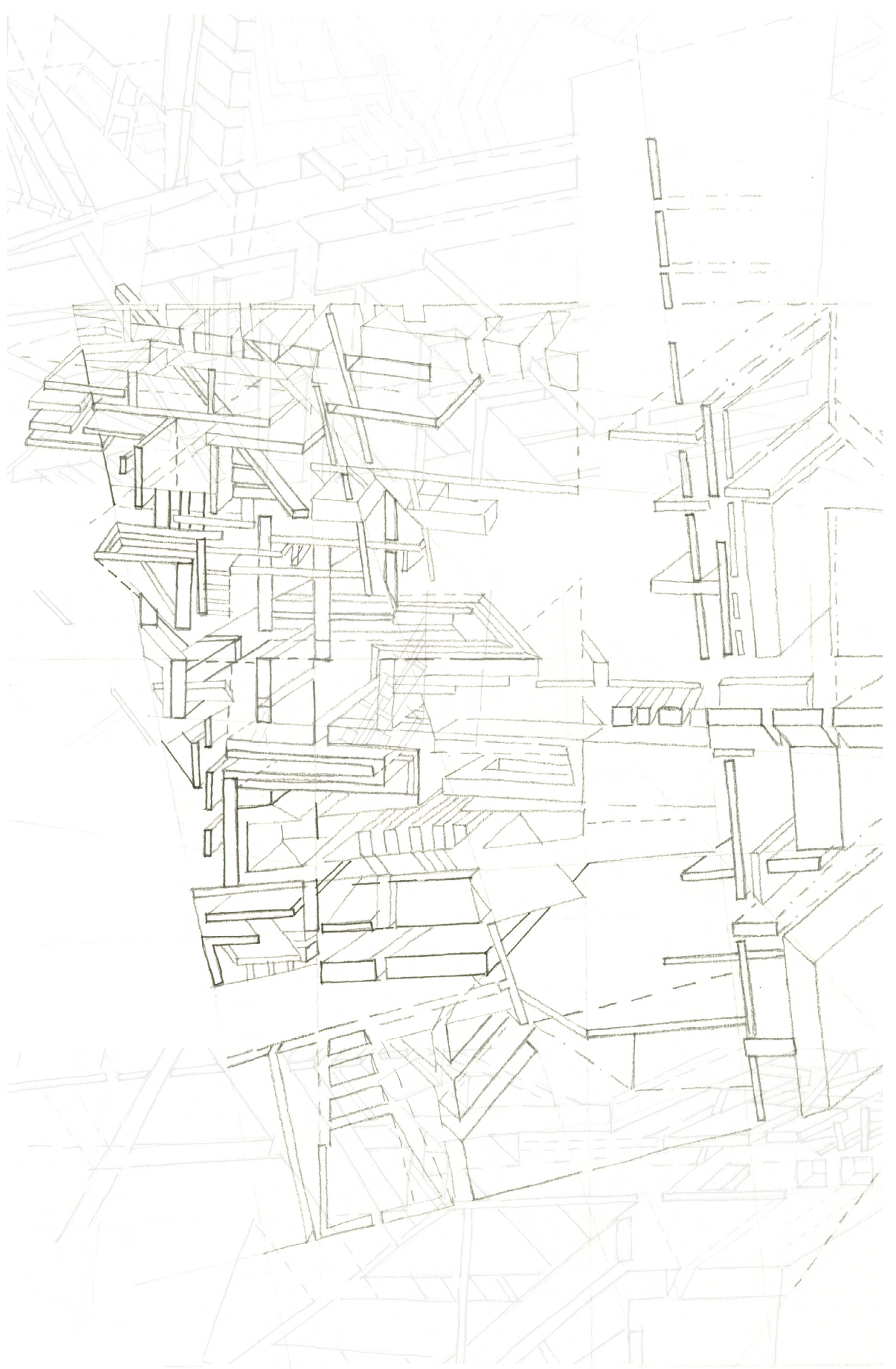




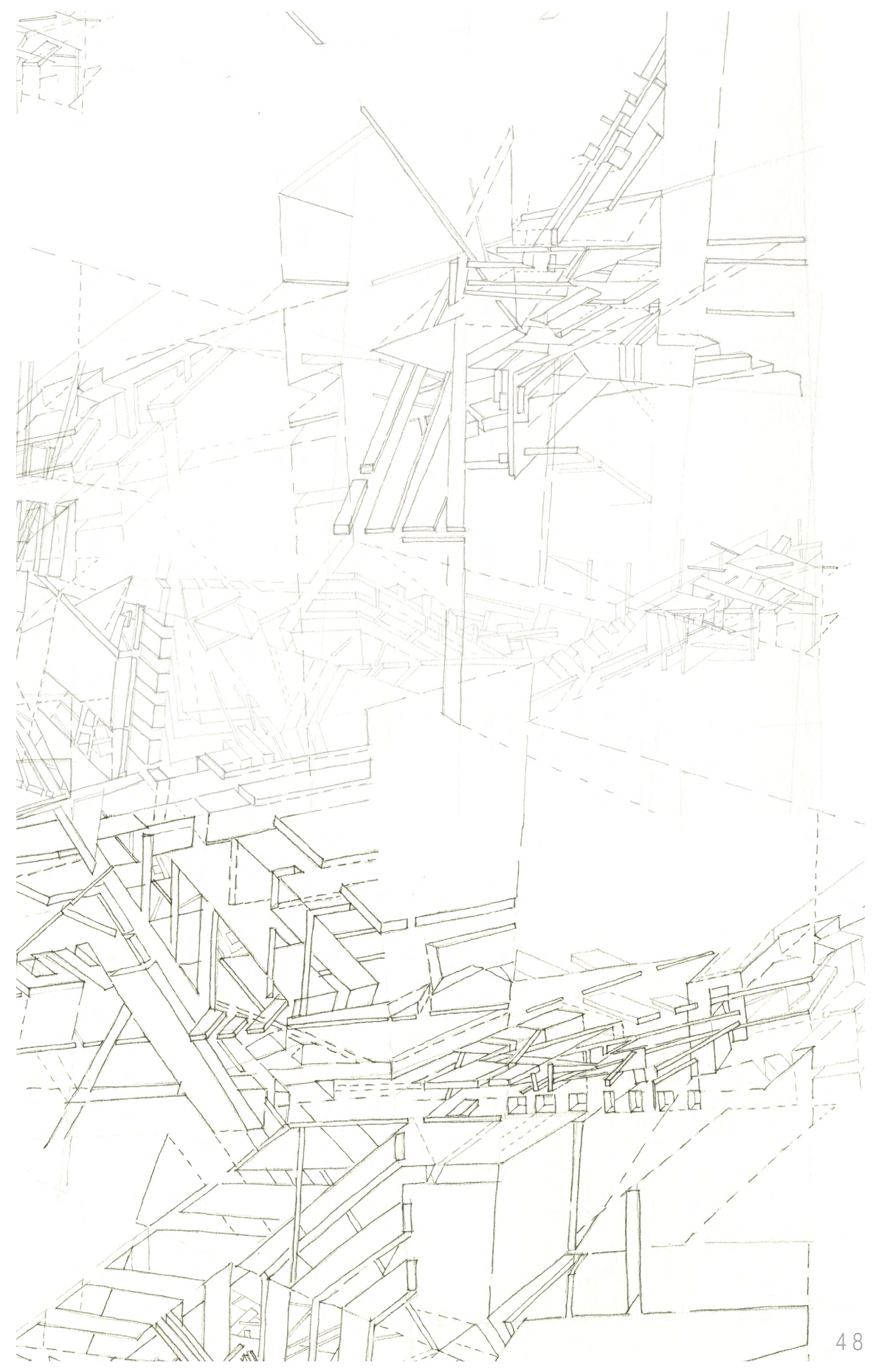




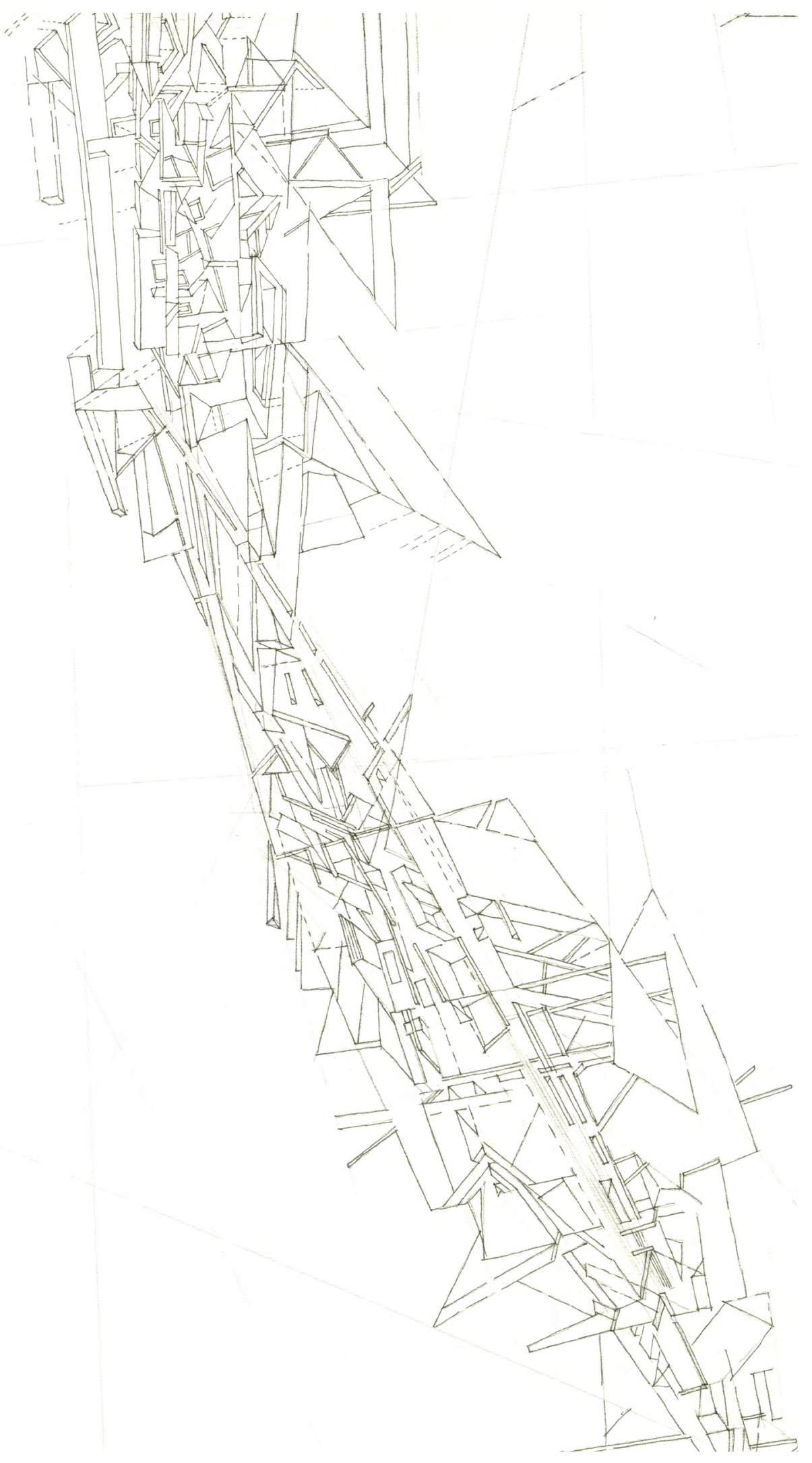




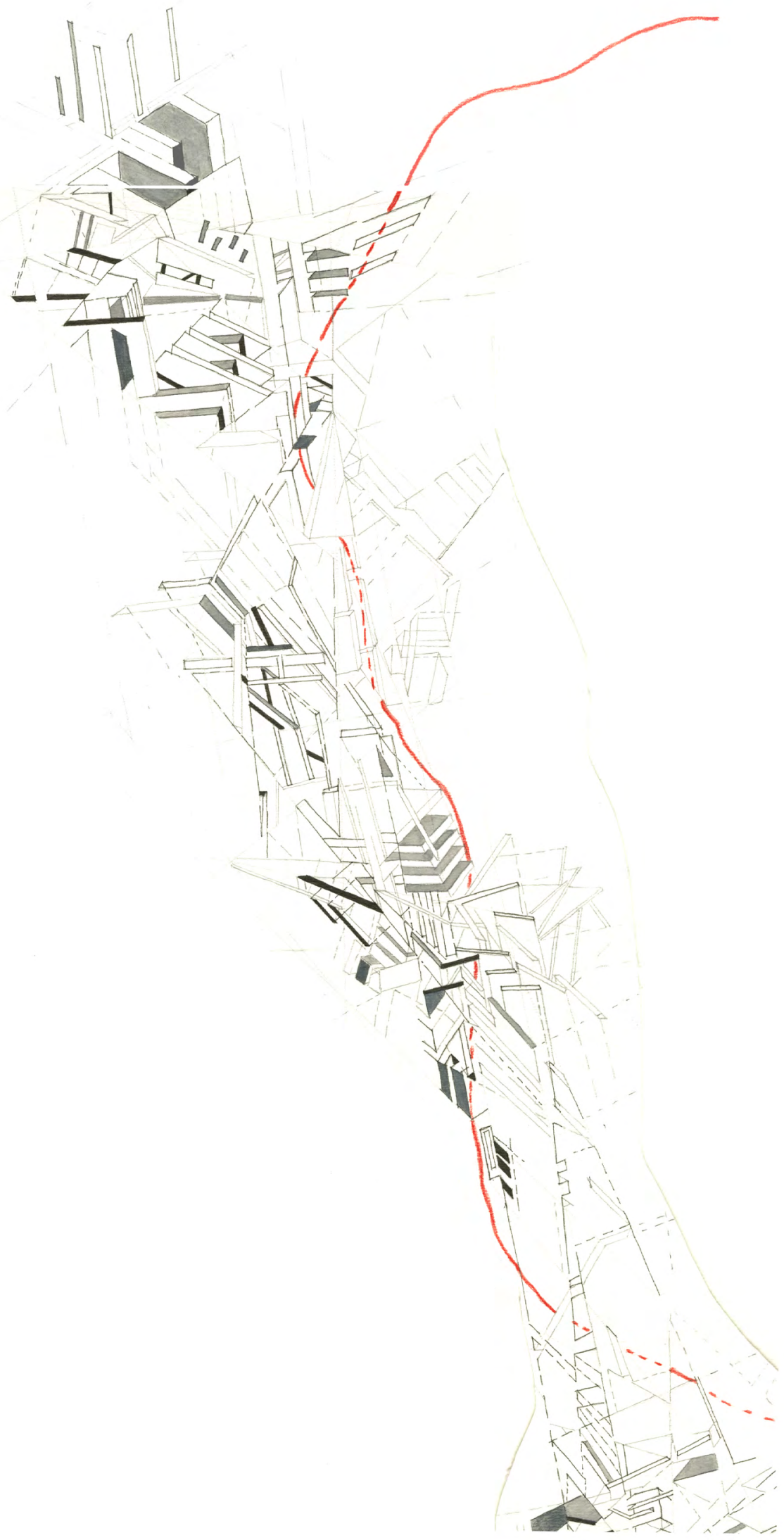

Lifeline 


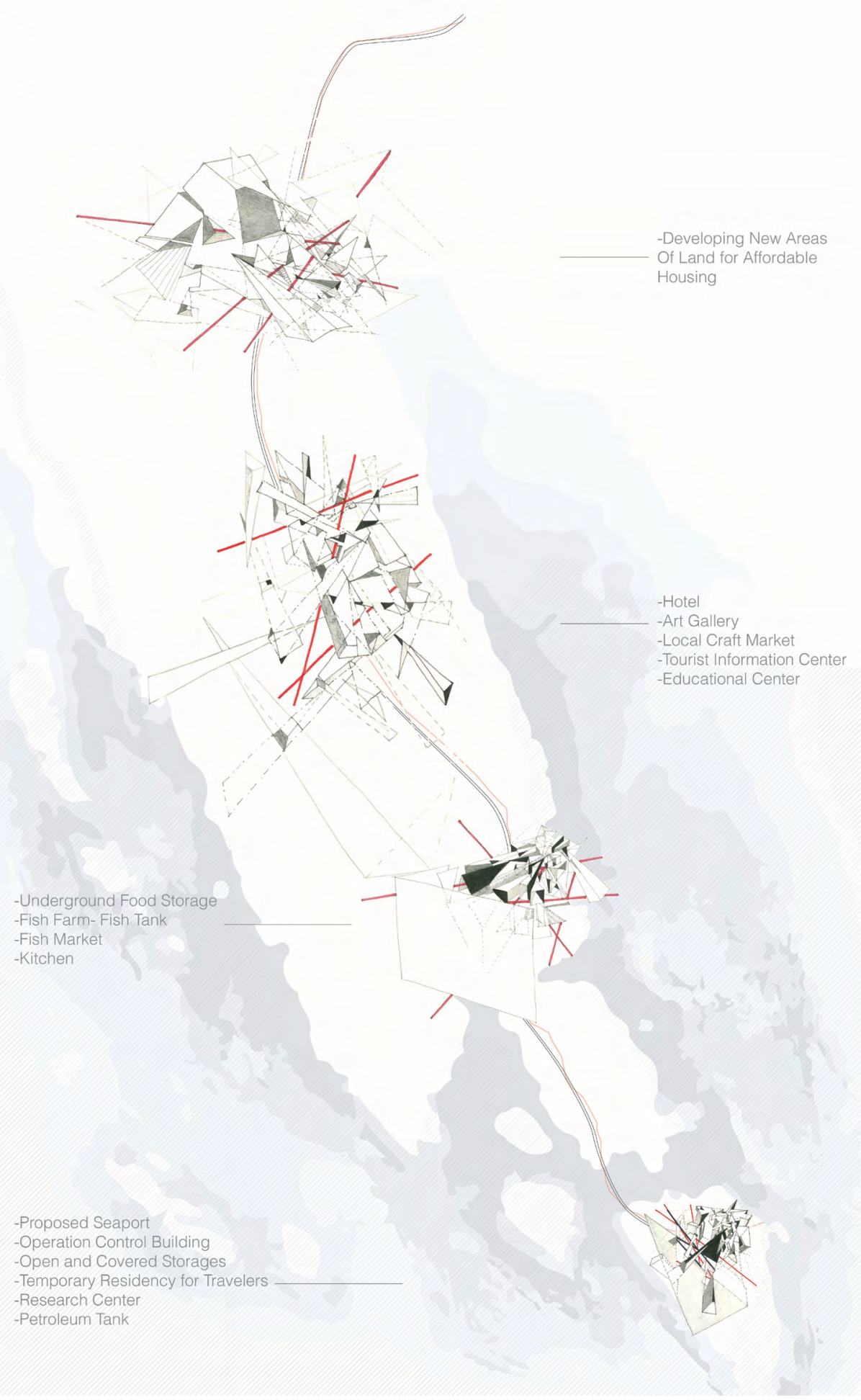

Lifeline 


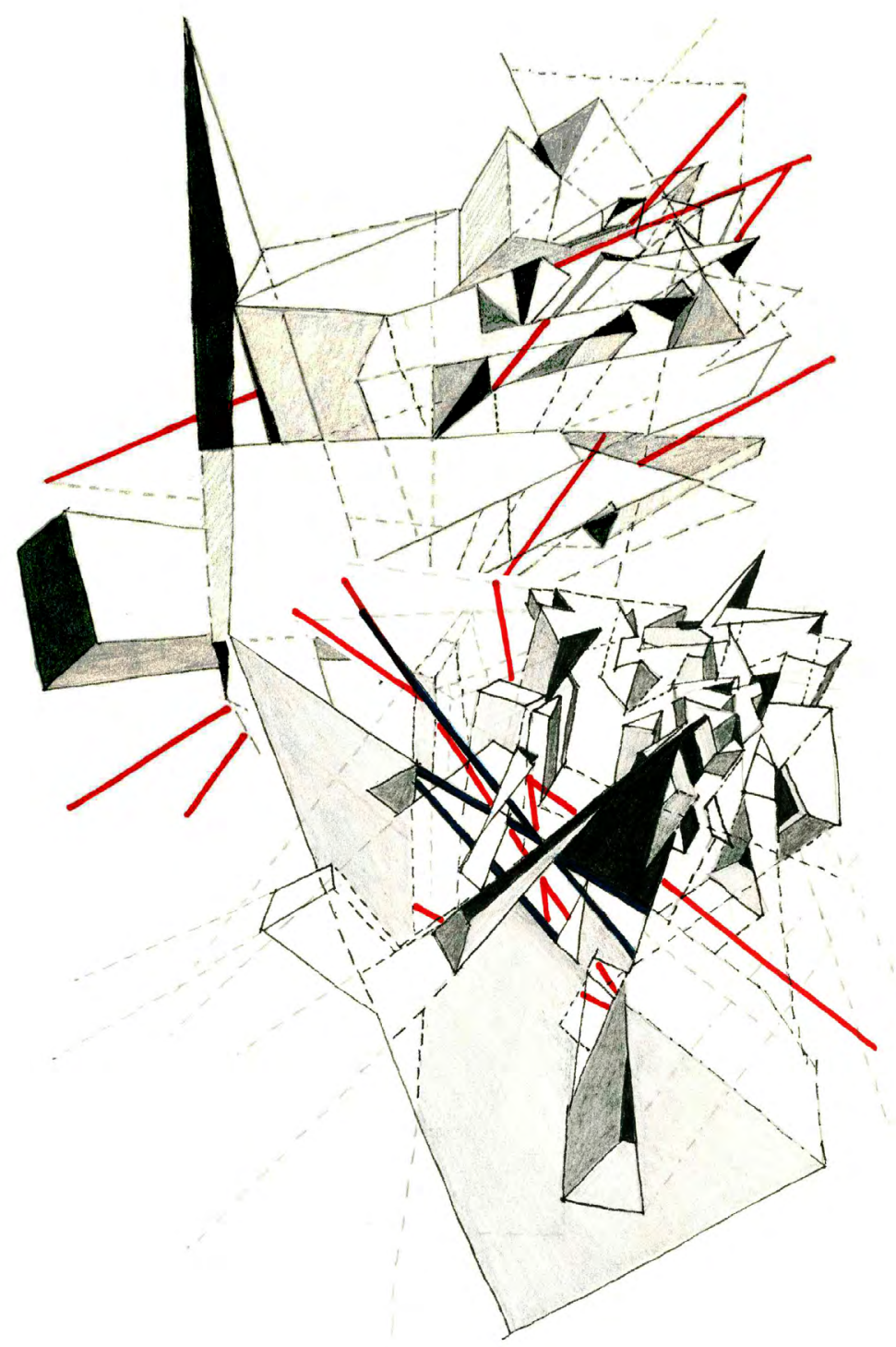




\section{RENDERING}

Three lines of thinking for designing the project is specified. Each of which relates to Inuit culture (content) and the harsh environment (context) are summarized as follows:

1 - The first one is the existing limitation of the site for development: Frobisher Bay is the second place in the world which has the highest rising tide that makes the Iqaluit inaccessible most of the time.

2 - The second aspect is creating a social life and social acceleration along lifeline. Exiting architectures in lqaluit and unpredictable conditions produce social isolation and this project seeks new possibilities for social acceleration and suicide prevention.

3 - The third aspect is that of the positive economic impact to provide job opportunities and income for habitants.

The key concept of the project is of a line of diverse spaces: long, short, broad, or tall spaces, each with different lighting conditions focusing on the idea of emptiness and nothingness of the North. Each volume relates to the defined space of the building and the interior space is dominated by series of voids, transparent and translucent skins allow direct and indirect lighting into the interior spaces. 
The building enclosure consist of solid and transparent volumes representing the connection between inside and outside space of the project. The unique geometry, scale and varying heights of each space offer organizational flexibility to accommodate different activity in each pod. The lightness of the transparent skins at different level, topped by solid part that float above, gives the building a sculptural quality. The use of different material reveals the programmatic uses inside: private spaces are exposed in solid form and public spaces are transparent, inviting viewer into the building.

The division of the interior space consists of the suspended pieces, capturing reflections of light penetrating the depths of the chambers coming into focus. To inhabit such a space is to exist between a multitude of possibilities.

By using movable boundaries to orginize public spaces such as fish market for different operation, space is gradually transforming into variant scales of subdivision, fragmented and isolated spaces, spaces that form in-between. Switching between these spaces allows for a manipulation of simultaneous chains of development. In effect, the lifeline project is an assemblage of spaces that are connected to the surrounding urban fabric, resonating with the linkage's role as a mediator between the Iqaluit community and the outside world.

Lifeline project pivots the new neighborhood to the downtown and transforming a vacant area of land into a dense, intense linear mixed-use neighborhood. 


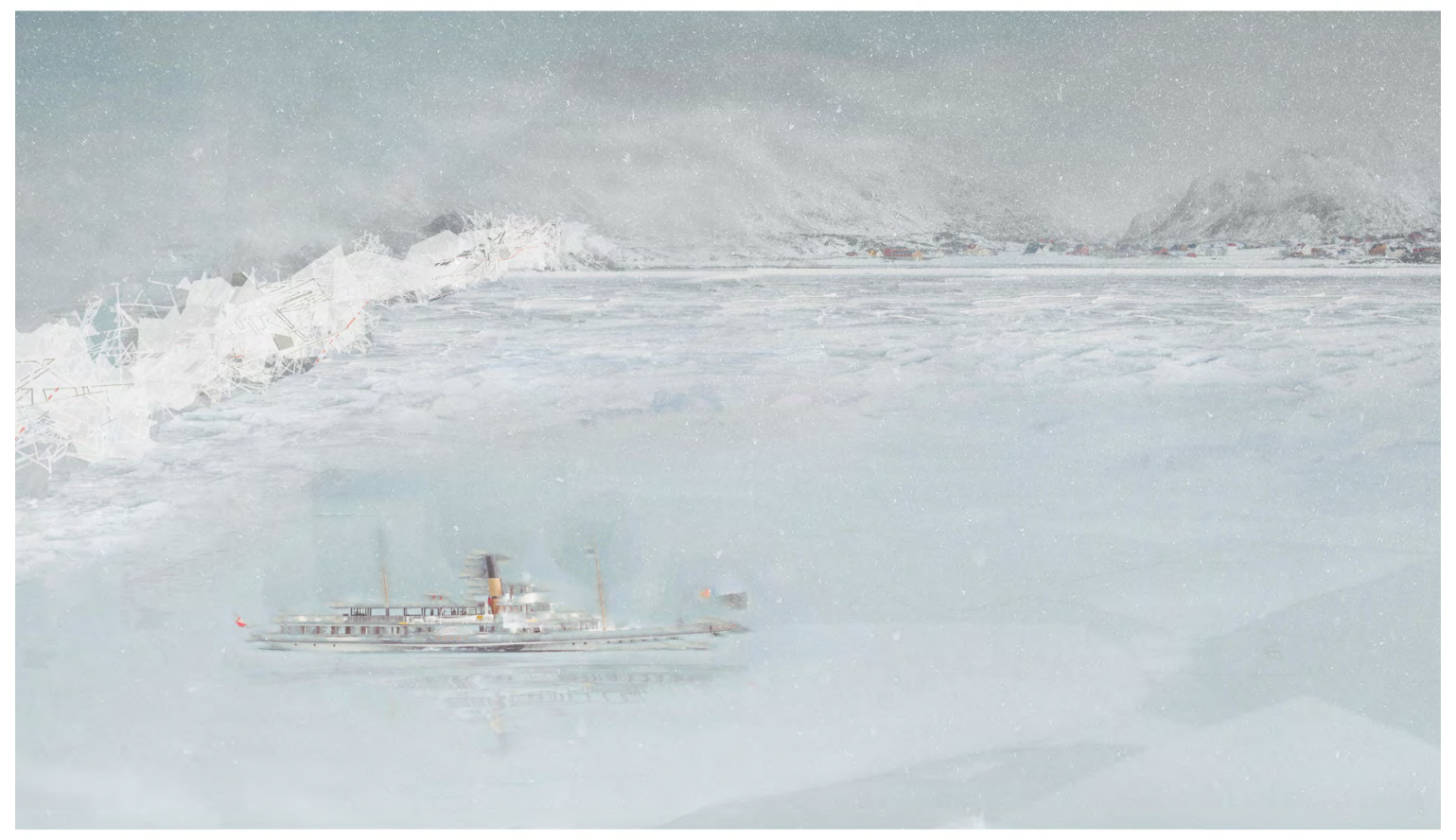


Dance for Inuit is to create a harmony between their physical world and spirituality. For Inuit their spirituality is connected to physical environment and life is seen as interconnected. Inuit use dance as a way to communicate with the spirit world.

Living in such a harsh environment is like dancing to create harmony between the environment and habitant in order to survive in complex condition and ensure that Inuit have a sound future are the goal of this project. 



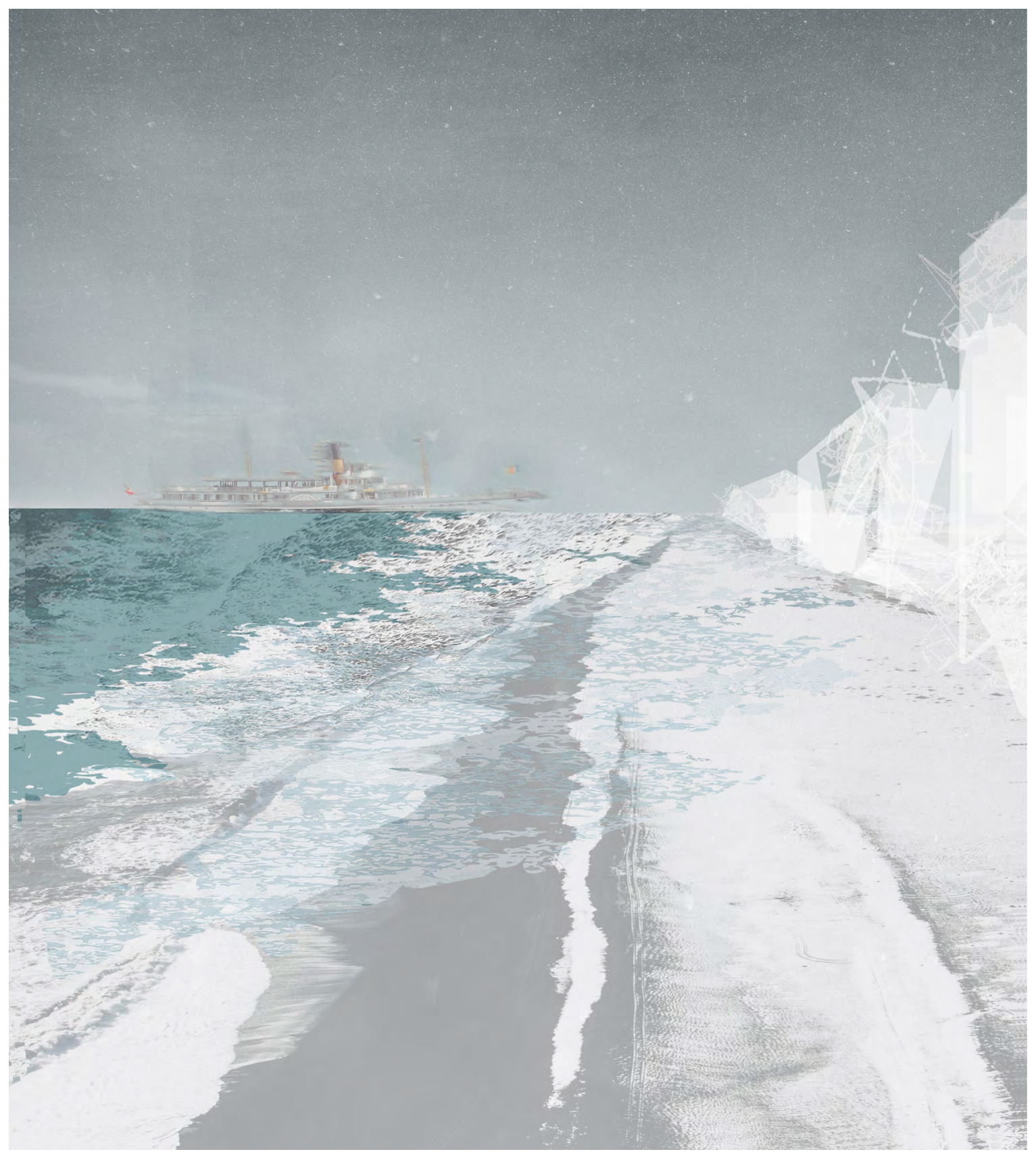




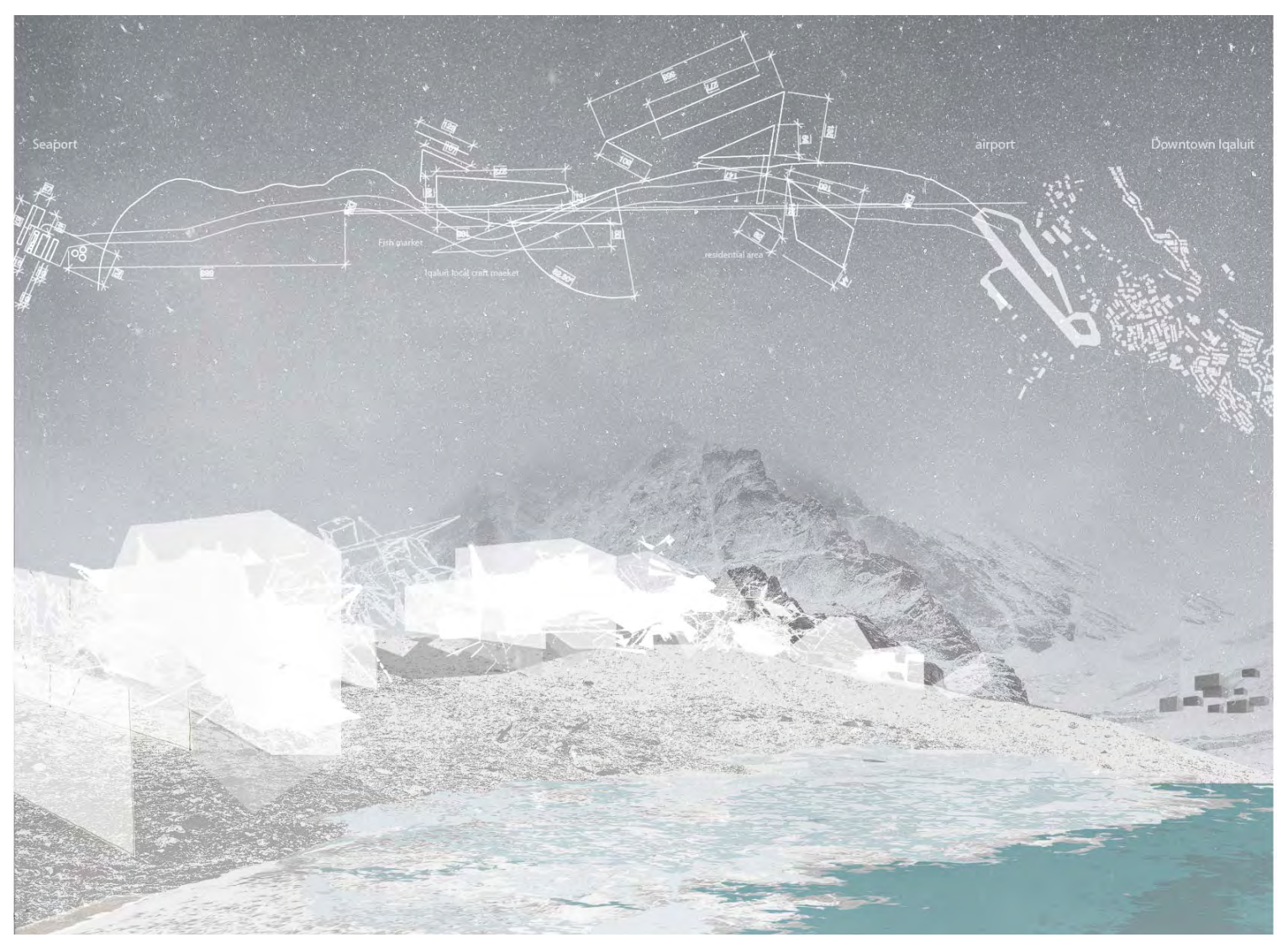




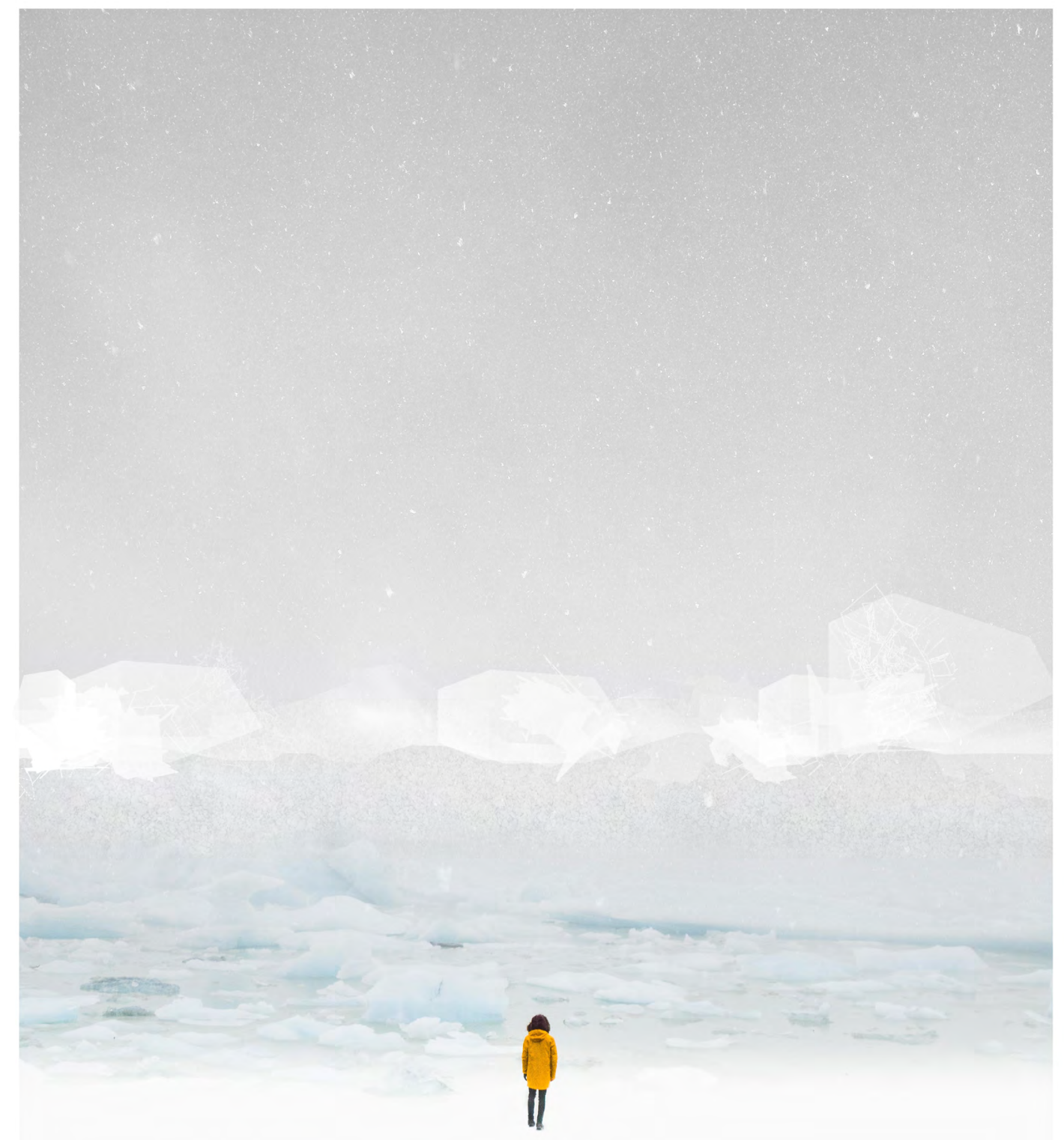


PROPOSED PROGRAMS:

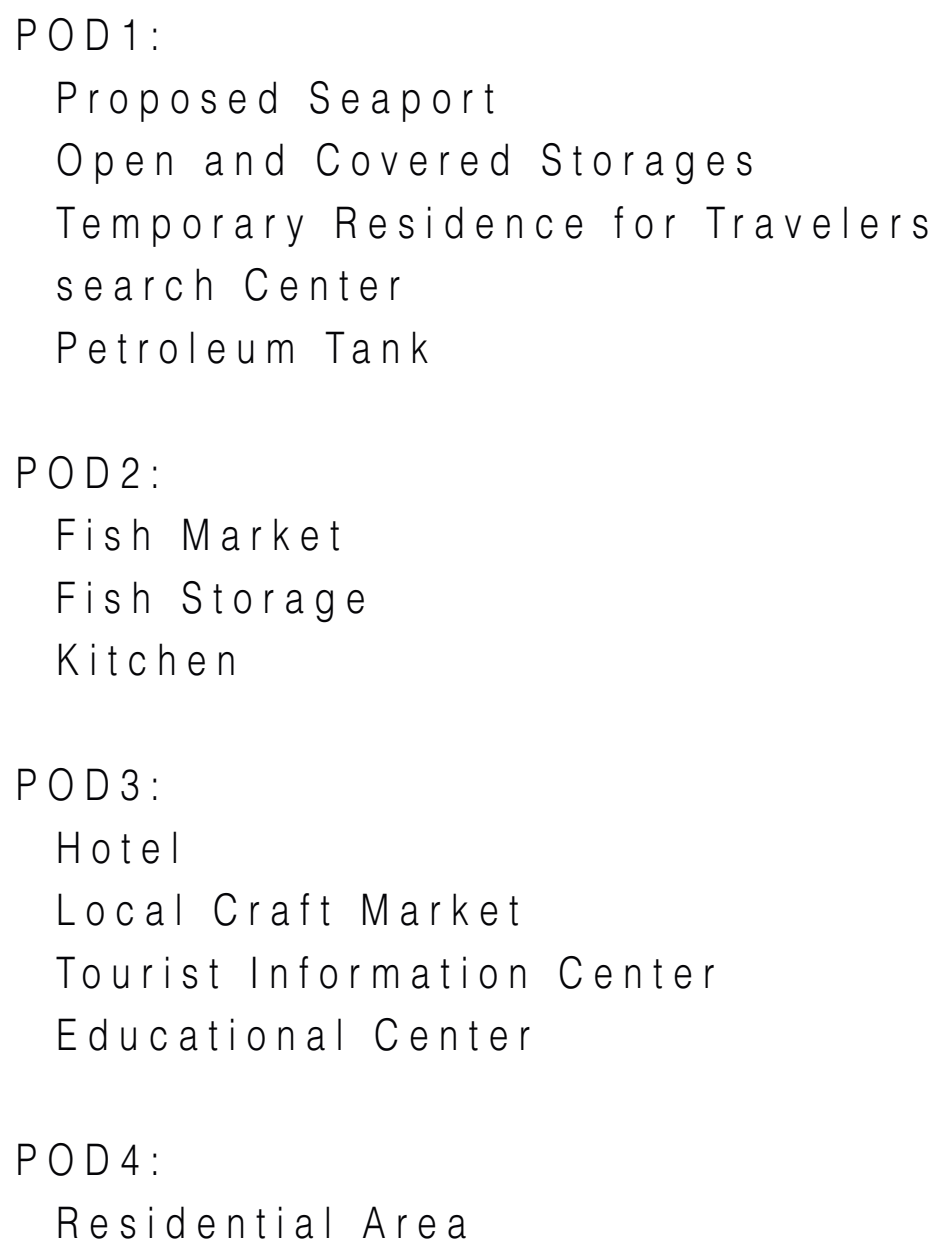


POD 1

POD 2

POD 3

POD 4

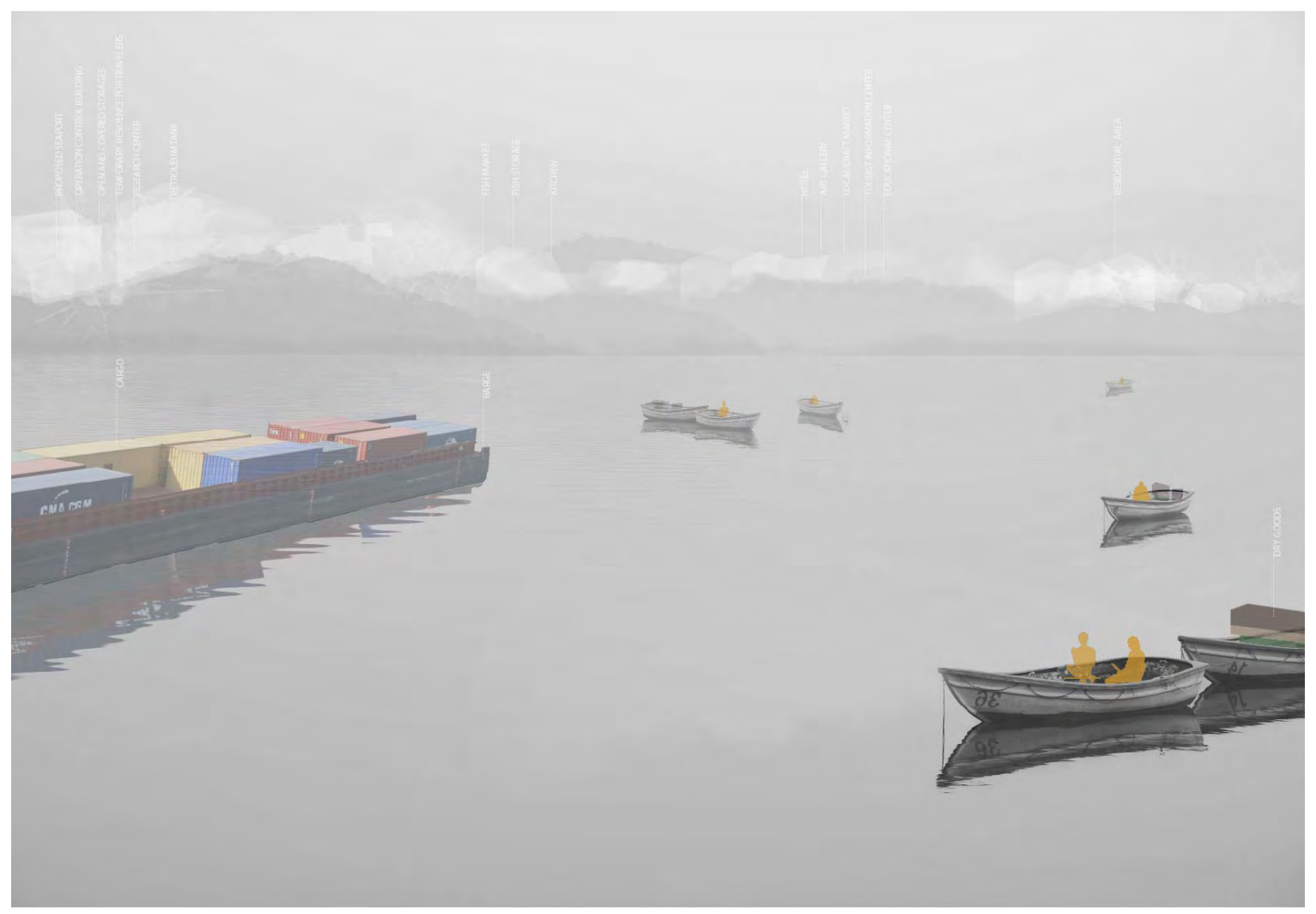




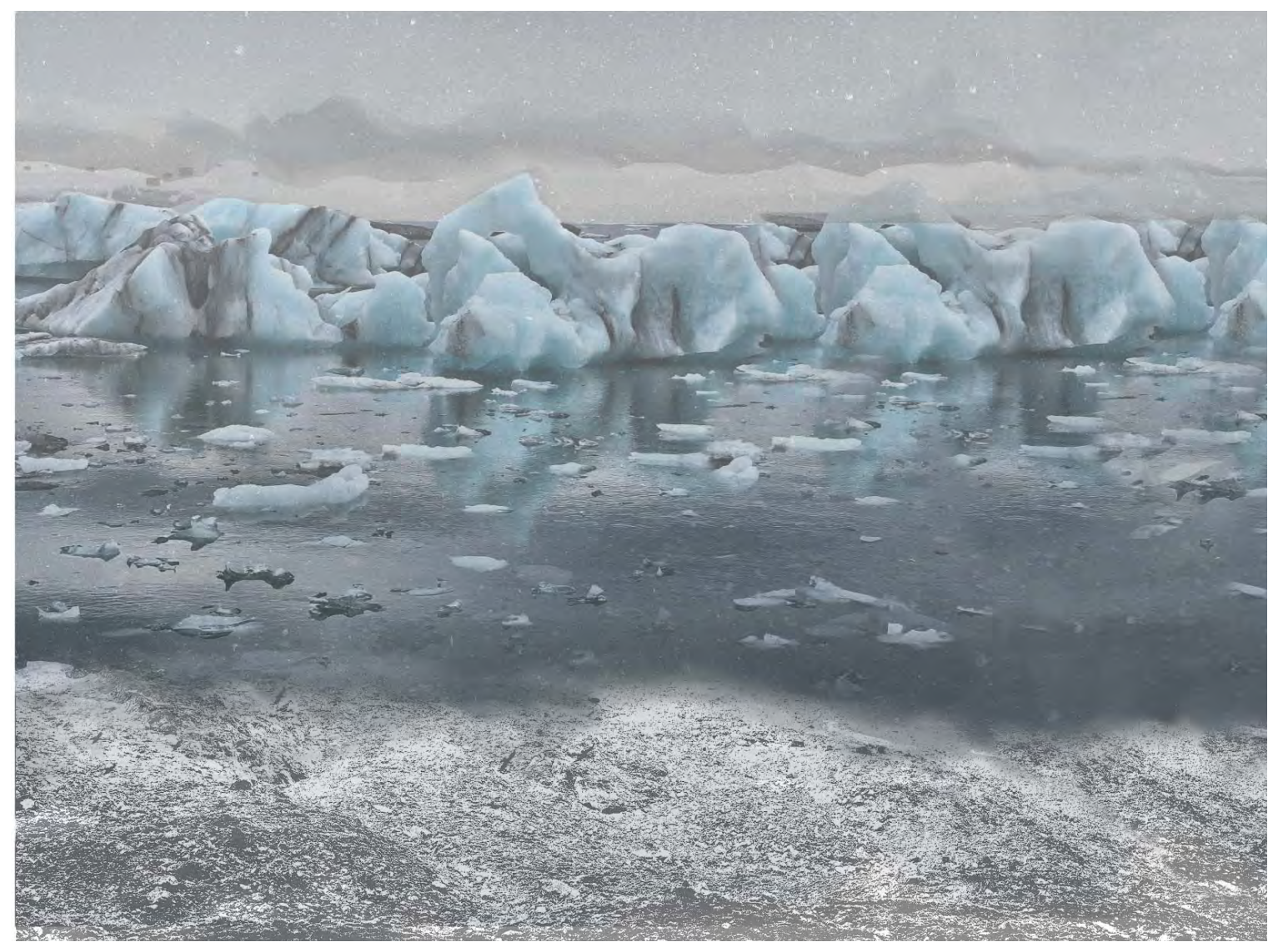




\section{APPENDIX A - \\ SITE ANALYSIS}

Seventeen years ago, Iqaluit became the capital of Canada's farthest northeast territory, Nunavut. It was around then that it began attracting more people from the Canadian south and even around the world. It's now the smallest territorial capital in Canada, while Nunavut is the largest Canadian territory. Since 1980 the population of lqaluit has grown from 2500 to 8000 . So, the annual volume of dry good and petroleum products being shipped to lqaluit have increased and other marine activities such as tourism have emerged as significant factor for consideration. So, that makes the development of new area of land for housing and infrastructure necessary. The Inuit leaders realized that new infrastructure would mean increased benefits to the communities in which they were loc ated.

Iqaluit is located on the shore of Frobisher Bay, an arctic estuary. Estuaries are some of the most productive ecosystems on earth. Simultaneously, because of their geographic features, estuaries provide great opportunities for development and safe navigation. Frobisher Bay provides access to lqaluit, and is home to Frobisher ship channel. This channel carries lqaluit's cargo ships each year and is representative of the intertwinement of industrial infrastructure and significant habitat. 
Beginning with the assumption that the marine industry will expand, this thesis asks how marine infrastructural strategies could develop to prepare for a future with low-impact development, estuarine recovery, supports the efficient shipping and trans-shipment of goods using the best environmental practices; and how the infrastructure necessary to serve and promote local industries including tourism, commercial fishing, mineral exploration and traditional pursuits could evolve.

"Much of Nunavut, Nunivak, and Nunatsiavuut, as well as many communities in Northwest Territories, rely on ports for access to shipped goods, fuel, and other basic needs." 12

The project provides speculative solutions for the considering future marine infrastructure such as an integrated deep-water port with a new extension to the downtown lqaluit in one coherent system of commerce, transit and housing. 
Iqaluit is strategically positioned to take advantage of new global shipping routes opening in the arctic. Iqaluit is a challenging location to build a port as it has the second highest rising tide in the world, with a 12 meter tidal flow. High tide in this area only happens 2 times during every 24 hours. So, ships have to stay far out at the sea, when they bring cargo and supplies. These supply have to be brought to the shore by barge and because they depend on tide levels, unloading can take several days. Deliveries taking place between late June and late October.

A new deep-water port is proposed and is the entry gate to the lifeline. "During the $1970 \mathrm{~s}$, a series of federal government studies led to preparation of a preliminary federal government engineering report in 1980 that recommended the construction of a concrete caisson wharf to handle the shipping of dry cargo and petroleum." 13 The need for deep-water port facilities in Iqaluit has long been recognized by lqaluit leaders and Federal government but the project did not proceed. ${ }^{14}$ The need for deep-water port facilitates serving all potential user groups of Shipping cargo, Fisheries, Tourism and Petroleum shipping. 


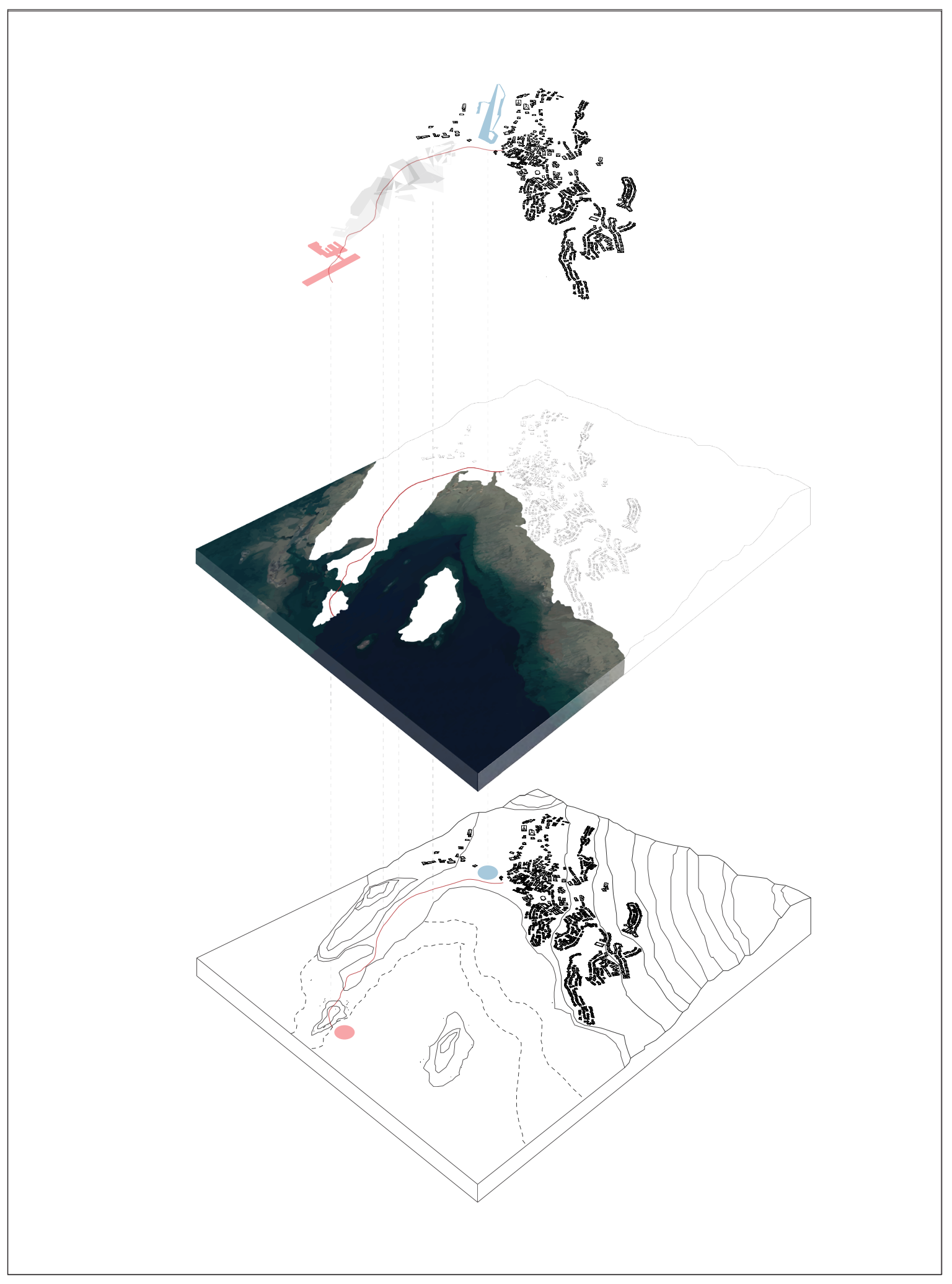

Site Analysis and Proposed Lifeline 


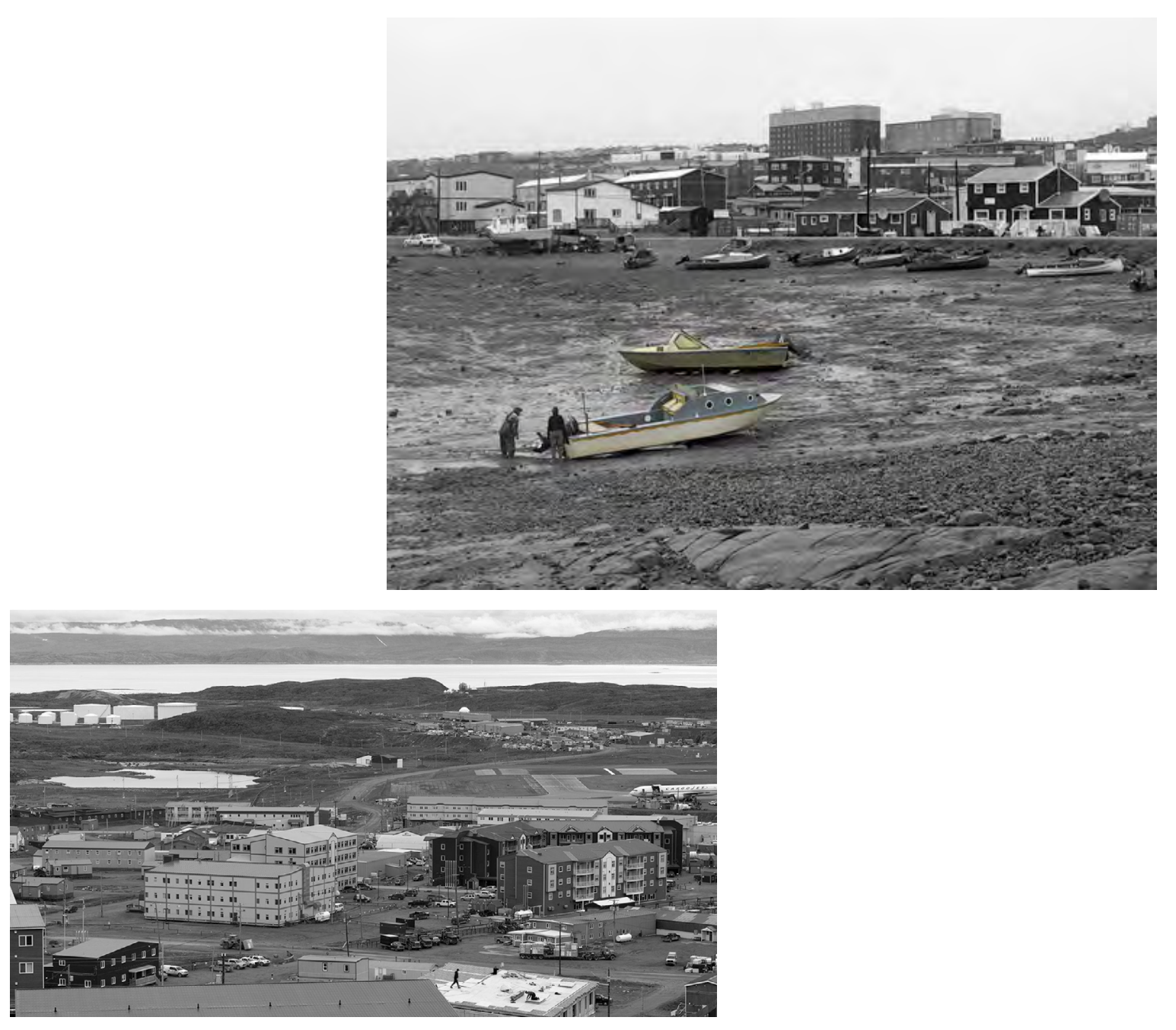

Iqaluit. High tide and Low tide 

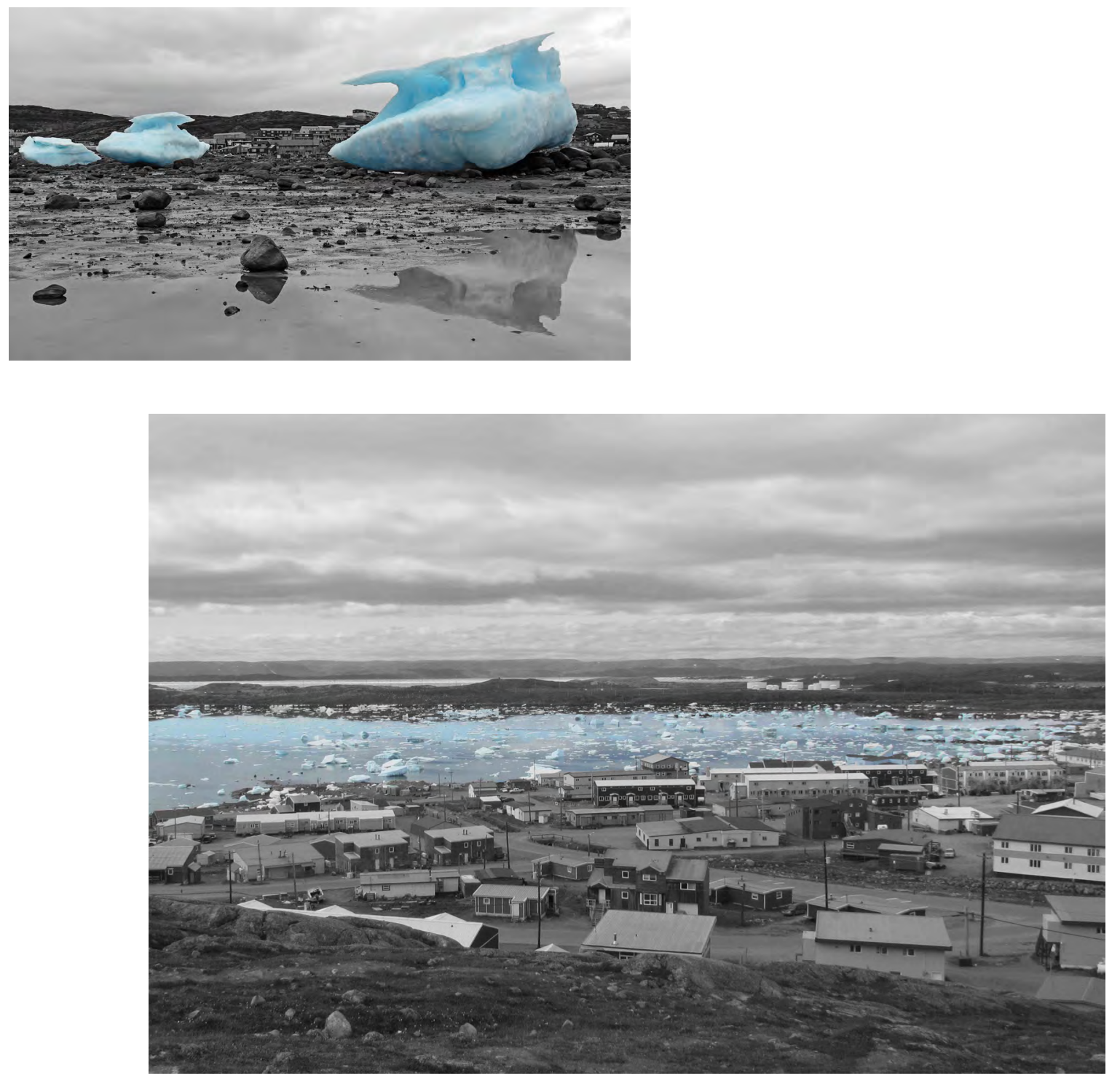

Iqaluit. High tide and Low tide 
Improvement marine industry supports:

$$
\begin{aligned}
& 1 \text { - cargo shipping } \\
& 2 \text { - petroleum shipping } \\
& 3 \text { - Fisheries } \\
& 4 \text { - Tourist cruise ship }
\end{aligned}
$$


Shipping Cargo

The cargo can be unloaded to shore from the vessel for a few hours during each 24 hours period at high tide. So, cargo is transferred to shore by barge. Under the present system, there is a risk of damage to cargo due to the rough water.

A deep-water port would reduce time spend unloading by almost $80 \%$, compared to current situation. ${ }^{15}$

\begin{tabular}{|l|l|l|}
\hline \multicolumn{2}{|l|}{ I qaluit Harbour Shipping Dates: } \\
\hline General Cargo & JUN & NOV \\
Petroleum Products Tanks & JUN & NOV \\
Fishing Vessels & JUL & NOV \\
Passenger Ships & JUL & SEP \\
Coast Guard lcebreakers & JUN & NOV \\
Small Crafts & JUN & NOV \\
\end{tabular}

Cargo Vessels: Days spent unloading [2 0003 ]

\begin{tabular}{|l|l}
\hline Minimum Days Unloading & 1
\end{tabular}

\begin{tabular}{l|l} 
Maximum Days Unloading & 14
\end{tabular}

\begin{tabular}{l|l} 
Avg. Days Unloading & 4.8
\end{tabular}

\begin{tabular}{l|l} 
Average Number of Cargo & 17
\end{tabular} 


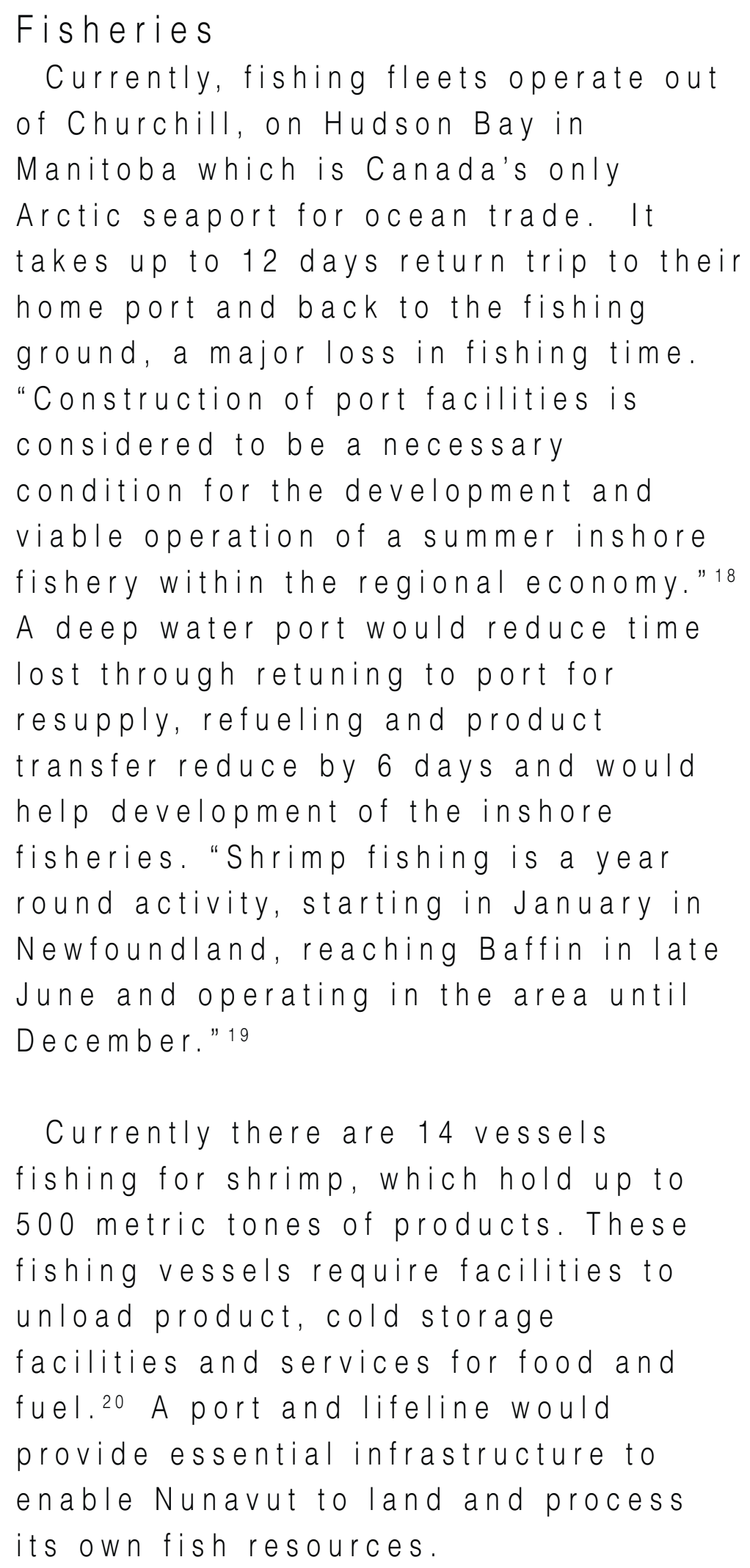




\section{Tourism}

The transfer of passenger to shore and back to ship is extremely risky operations and only could happen in high tide due to the lack of facilities. ${ }^{21}$

\section{Small Craft}

Small craft operation depends on high tide which is almost 12 meters. Loading, unloading, transferring passengers and cargo can be done during 2 hours every 12 hours at high tide.

Petroleum Shipping

The current method of unloading petroleum tankers, creates a very high environmental risk. Time spend unloading could be reduced by $60 \%$, from 16 to 6 days annually, - compared to current situation. ${ }^{22}$

\begin{tabular}{|l|l|}
\hline \multicolumn{2}{|l|}{ Petroleum Product Tankers: } \\
Days spent transferring \\
products [2003] \\
\hline Minimum Days Unloading & 2 \\
Maximum Days Unloading & 5 \\
Avg. Days Unloading & 3.3 \\
Average Number of Petroleum & 4.4 \\
Shipments & \\
\hline
\end{tabular}


Existing services and accommodation in Iqaluit (downtown):

-Banking: RBC, CIBC, First Nations Bank of Canada.

-Emergency services: RCMP

- Medical Services: The Qikigtani General Hospital,

Dental Offices, Pharmacies,

Chiropractors, Massage Therapists, a Public Health unit, a Family Practice Unit.

-Religious Services: Churches

-Schools: Four elementary schools, One middle school, One secondary school.

- Daycare: Several daycares

- Recreational Services: Social Clubs

- Capital Suites

- Hotel arctic

-Frobisher Inn

- NorthMart

- Arctic Ventures Marketplace

-Baffin Island Canners

Proposed Supplies in Lifeline's Pods:

At the fist pod, creating a port, Temporary Residency for Travelers are proposed. The other suggestion is to create a basin on one side of the port and using the tidal energy system under water. So, as the water rise and fall, the movement of the water runs the turbine and it generate electricity for the whole site. 
At the second pod, there is a fish farm, fish market, fish storage, kitchen. At the third pod, there is a hotel, art galley and local craft market on the midway between the entry gate and downtown lqaluit. At the closest pod to the downtown lqaluit, developing new area of land for affordable housing is proposed.

A linear city will be created along lifeline and an interconnected connection between each pod and landscape will be formed. It would be a city with different type of seasonal and permanent structure. The major activities take place in each pod and in between the pods, minor activities take place.

Construction of a entry gate and lifeline in lqaluit would change the economics of the whole picture, making lqaluit a gate to the northern part of arctic. The proposed seaport is taken as an entry gate to lifeline and the lifeline is creating a continuous connectivity between the sea port, air port and downtown lqaluit. The viewer's uninterrupted journey through the project starts outside at the seaport, allowing visual connectivity into the other levels of the project. The sealift vessels carry containers in Arctic constitute a vital Lifeline on the water from southern to northern communities and proposed seaport in lqaluit act as an entry gate for another Lifeline on the ground as well. "Despite the challenges, sealifting continues to expand with the opening up mining, global interest in the Northwest Passage route, and longer ice-free shipping periods." 24 
Goods transport, airlift and sealift:

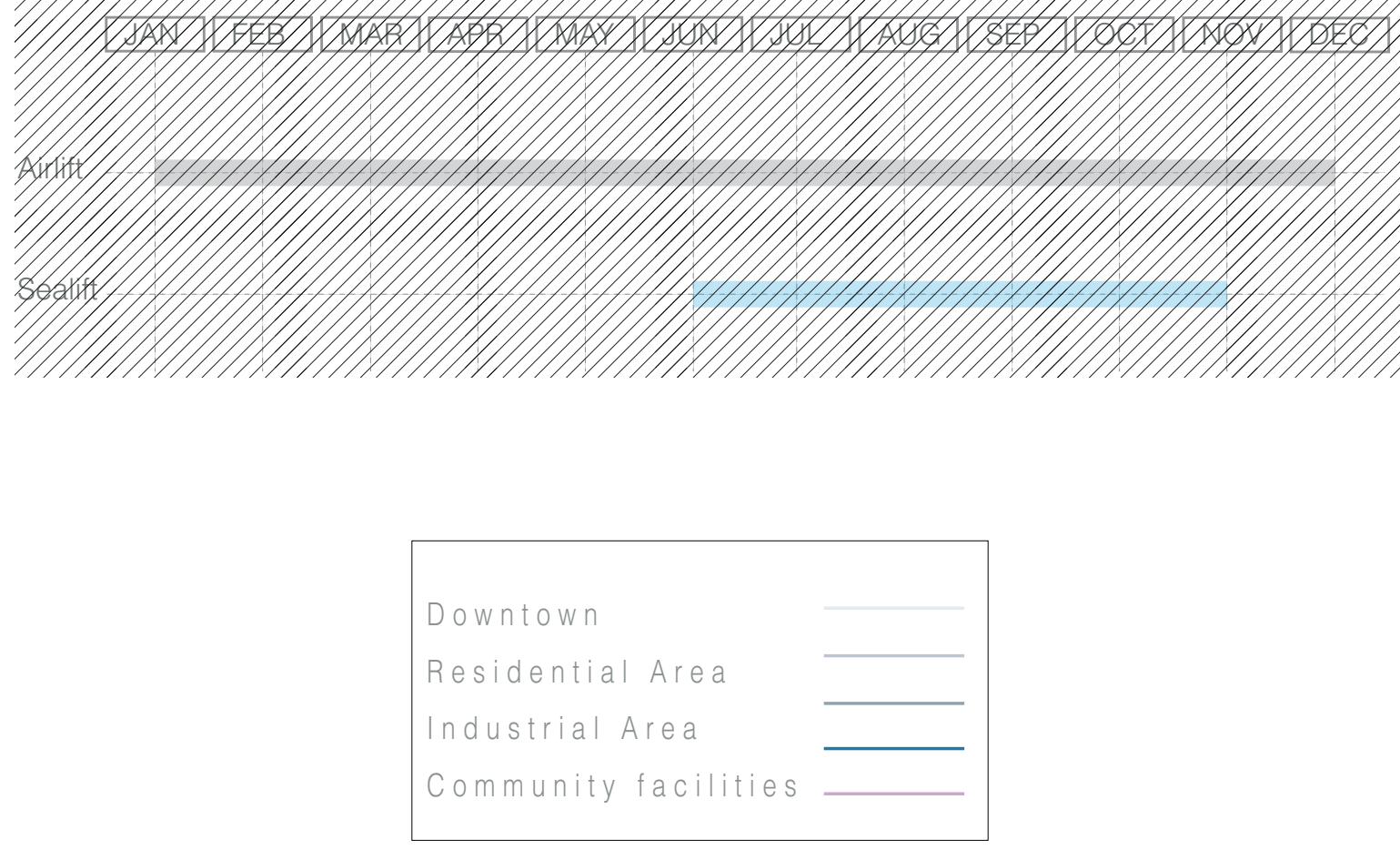




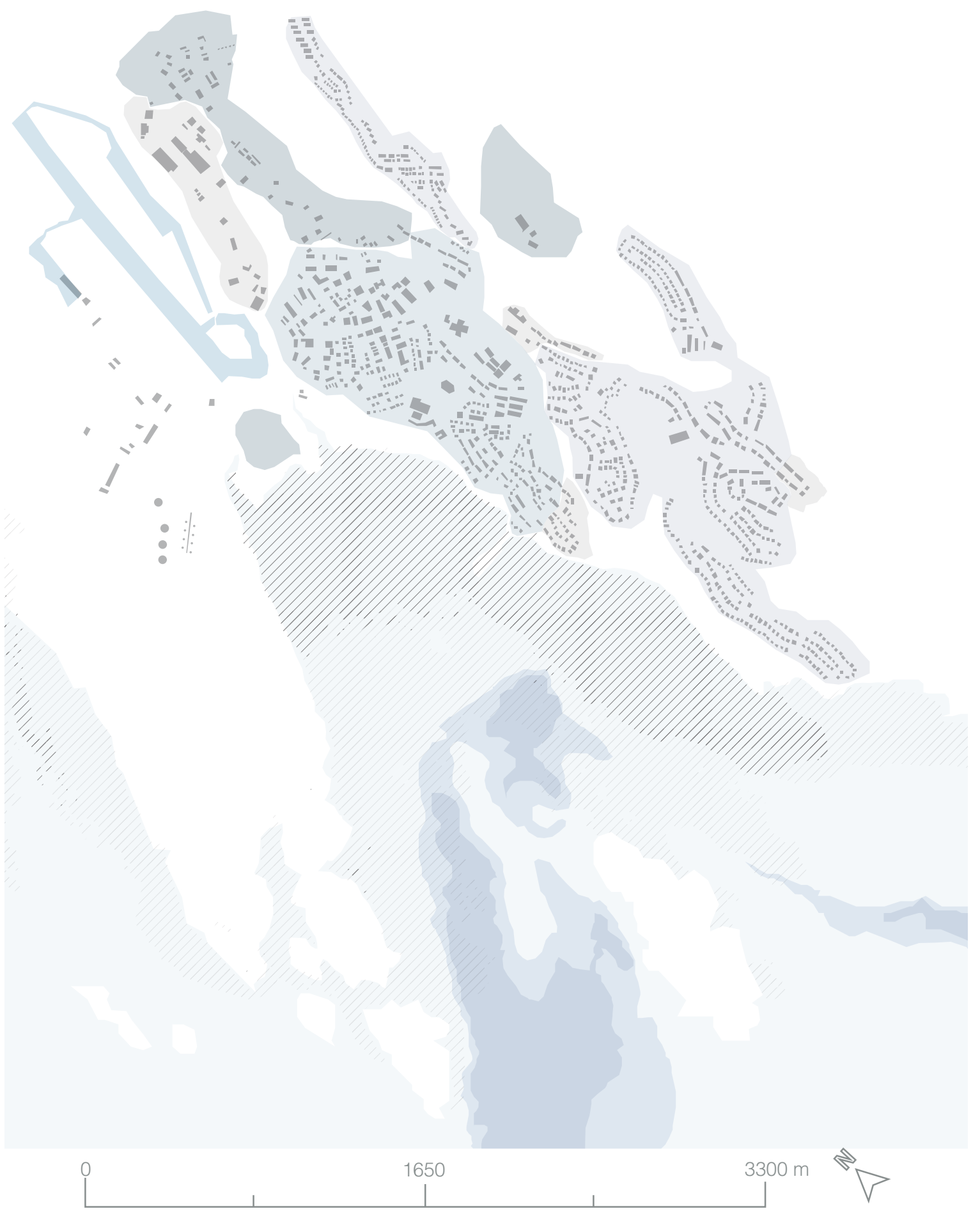




\section{LEGEND:}

- Nakasuk School

- Nunatta Sunakkutaangit Museum

- Northmart

- Iqaluit Centennial Library

- First Air Cargo

- Baffin Business Development Corporation

- Arctic Circle Dental Service Ltd

Nunavut Auto-Heavy Equipment

- Carrefour Nunavut

- Judge's Anglican Cathedral

- $\mathrm{CIBC}$

1 Iqaluit Post Office

- Legislative Assembly of Nunavut

- Frobisher Inn

- Centres Service Canada Government of Canada Bld

- Nunatsiaq News

- Iqaluit MCTS and Storage Facility

Airport

Existing pipeline

Primary snowmobile trails

DEPTH CONTOURS:

$0 m-5 m$

$-5 m-10 m$

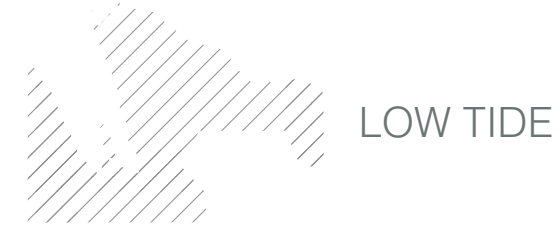

$-10 m-15 m$

- $15 \mathrm{~m}-30 \mathrm{~m}$

PROPOSED:

GOODS TRANSPORT:

$20^{\prime} \times 8^{\prime}$ container

Proposed port

ImIstrir Proposed Railway-LifeLine

Goods

Vehicles

', Proposed Pod

Construction materials 


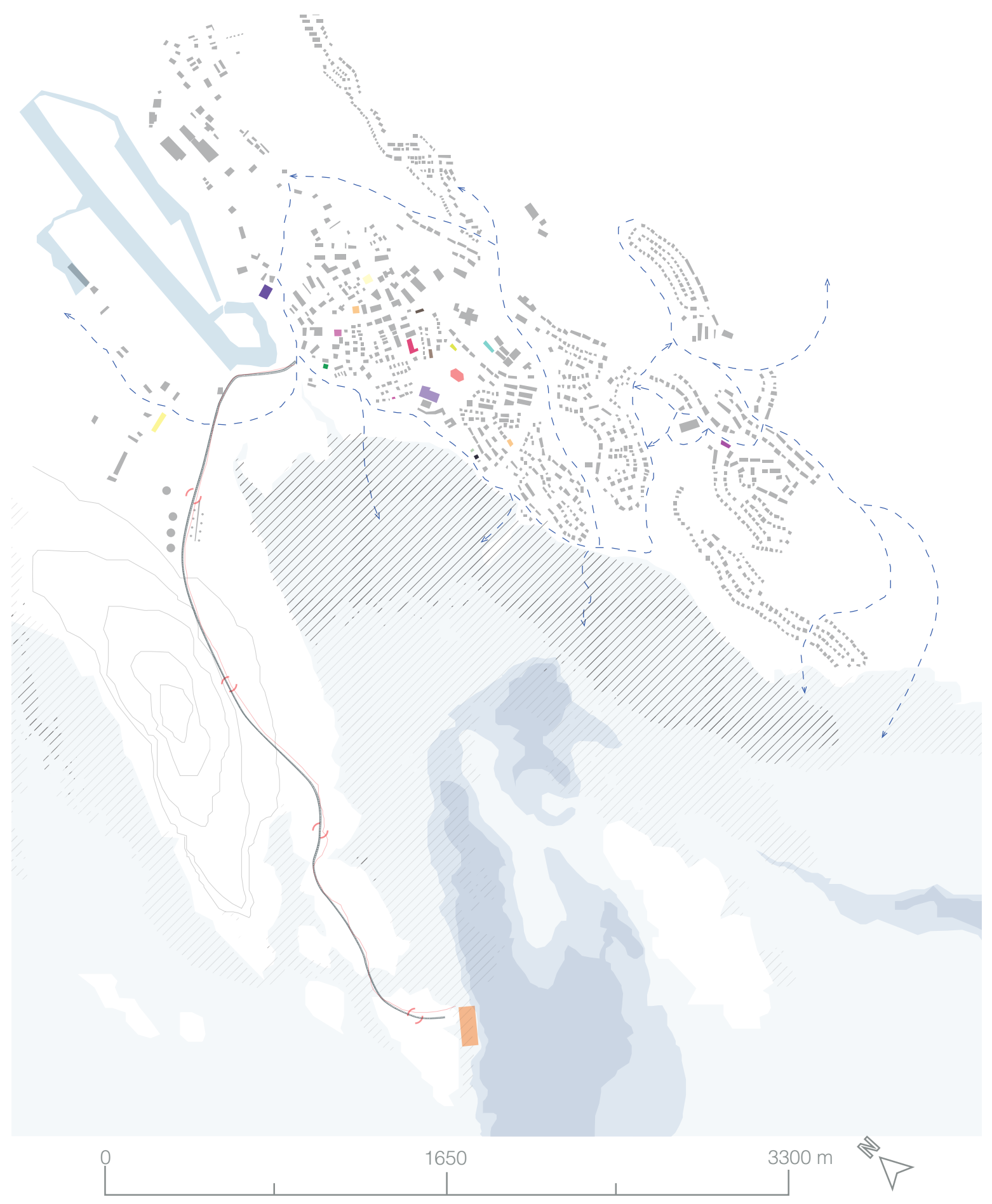




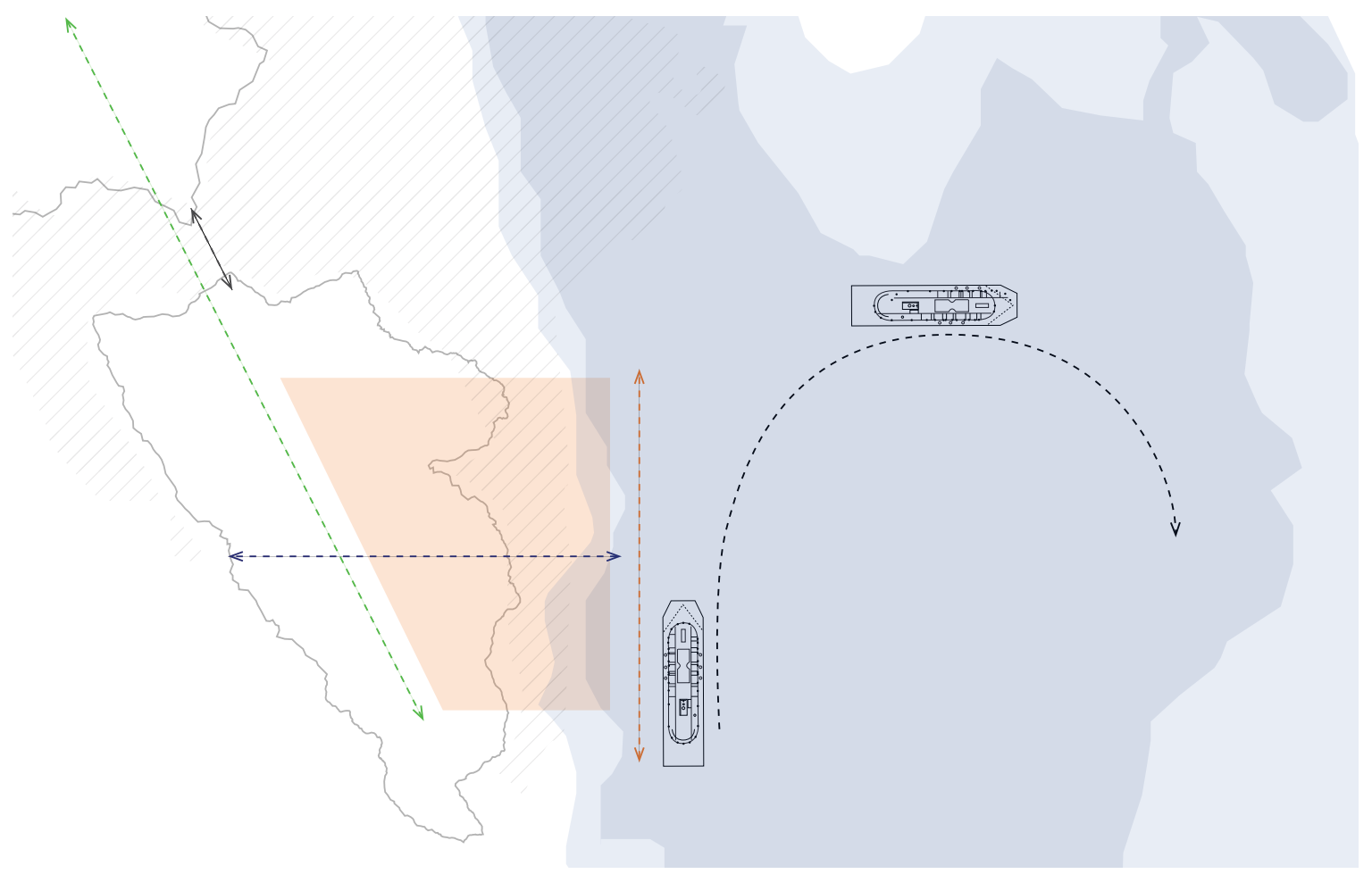

LEGEND:

Location of Project

Depth $10-15 \mathrm{~m}$

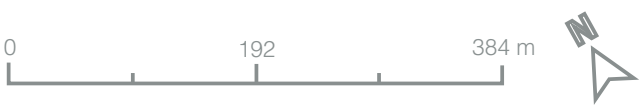

Depth 15-30m

$\div$ Bridge

i Proposed Port

Urban Area Link

4 - $\rightarrow$ Landside Link to Seaside Link

$i^{-\cdots}$ Ship Turning Radius 


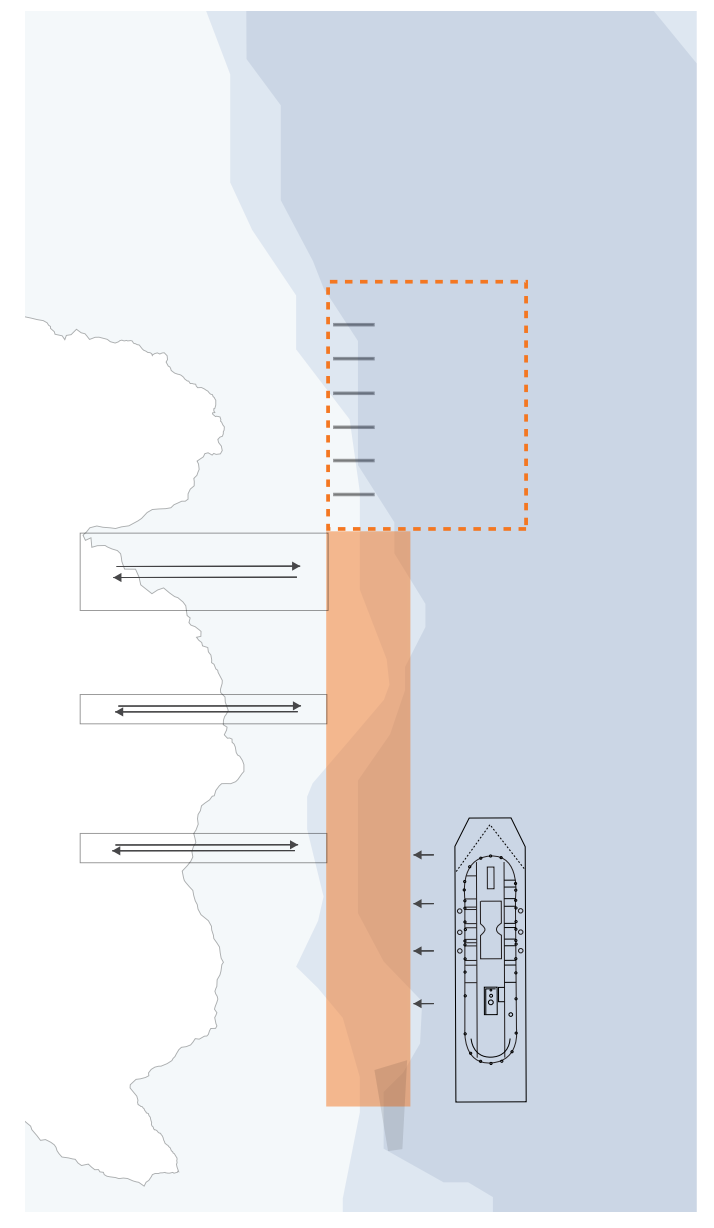

\section{TYPE OF VESSELS: \\ MV Mitiq 136m x19m

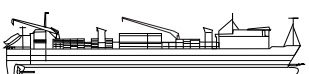

MV Avataq 113m x19m

表 1

LEGEND:

A Designated Area For Maintenance And Safe Storage Of Small Craft

$\rightleftarrows$ Bridge

Free Stand Port Provides: -Docking Facilities -Covered Storage -Open Storage 
Times and Heights for High and Low Tides

2017/12/04

$\begin{array}{lllllllllllll}\text { Hour } & 00 & 01 & 02 & 03 & 04 & 05 & 06 & 07 & 08 & 09 & 10 & 11\end{array}$ Predicted

$\begin{array}{lllllllllllll}\text { Hourly } & 1.3 & 1.0 & 2.2 & 4.3 & 7.0 & 9.4 & 11.1 & 11.6 & 10.7 & 8.7 & 6.2 & 3.6\end{array}$ Heights (m)

$\begin{array}{lllllllllllll}\text { Hour } & 12 & 13 & 14 & 15 & 16 & 17 & 18 & 19 & 20 & 21 & 22 & 23\end{array}$ Predicted

$\begin{array}{lllllllllllll}\text { Hourly } & 1.5 & 0.6 & 1.1 & 2.9 & 5.4 & 8.0 & 10.0 & 11.0 & 10.7 & 9.2 & 7.0 & 4.4\end{array}$ Heights (m) 


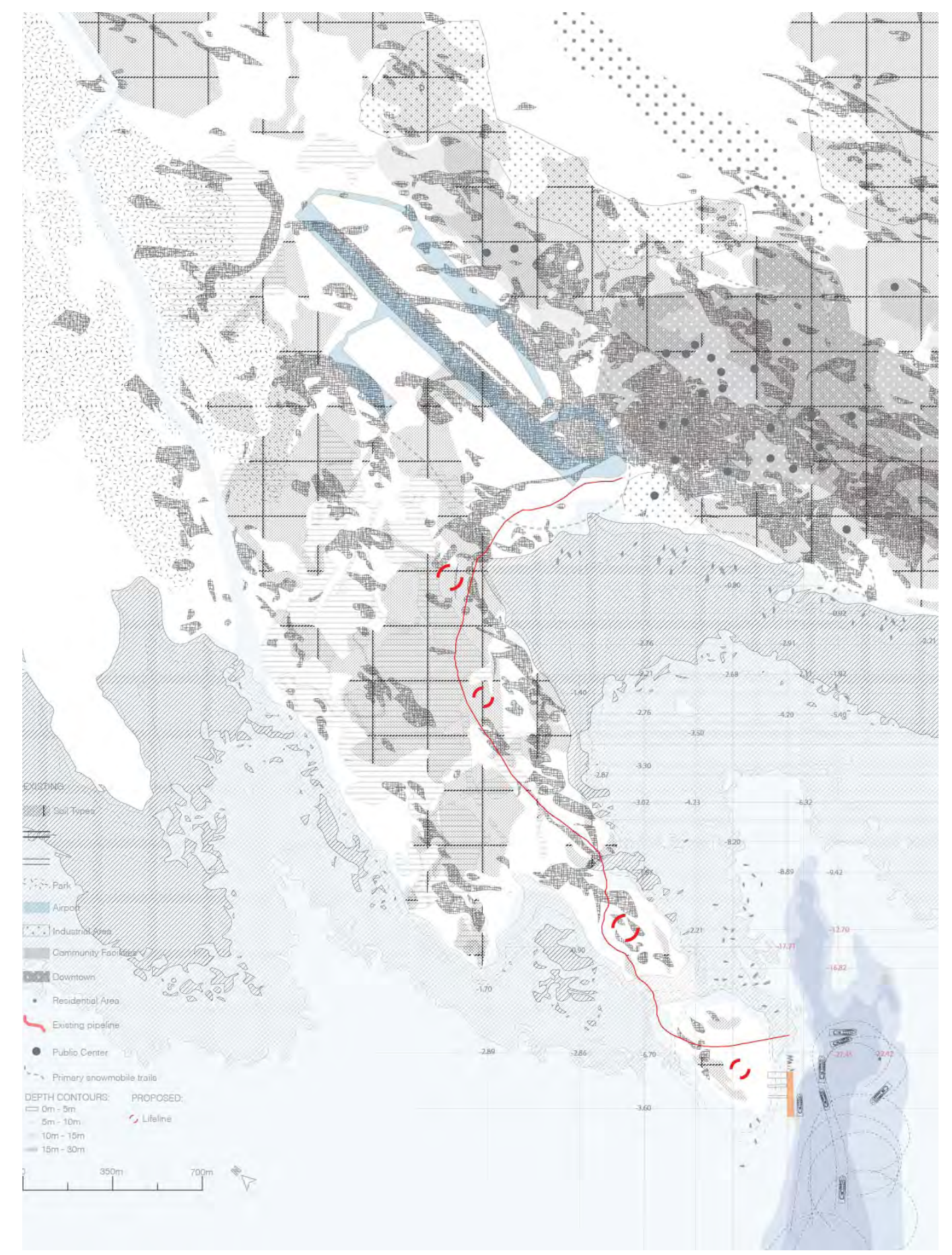




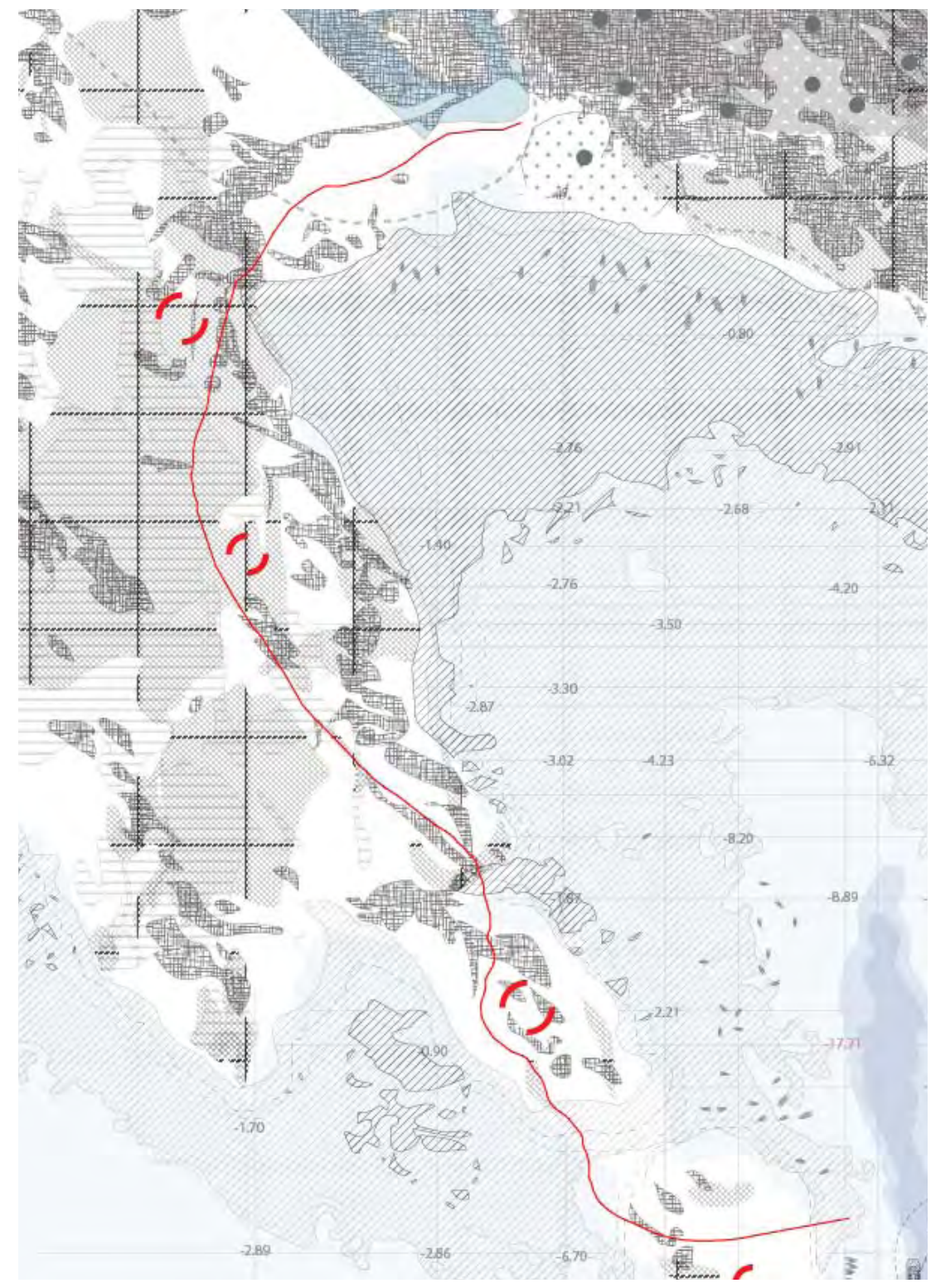




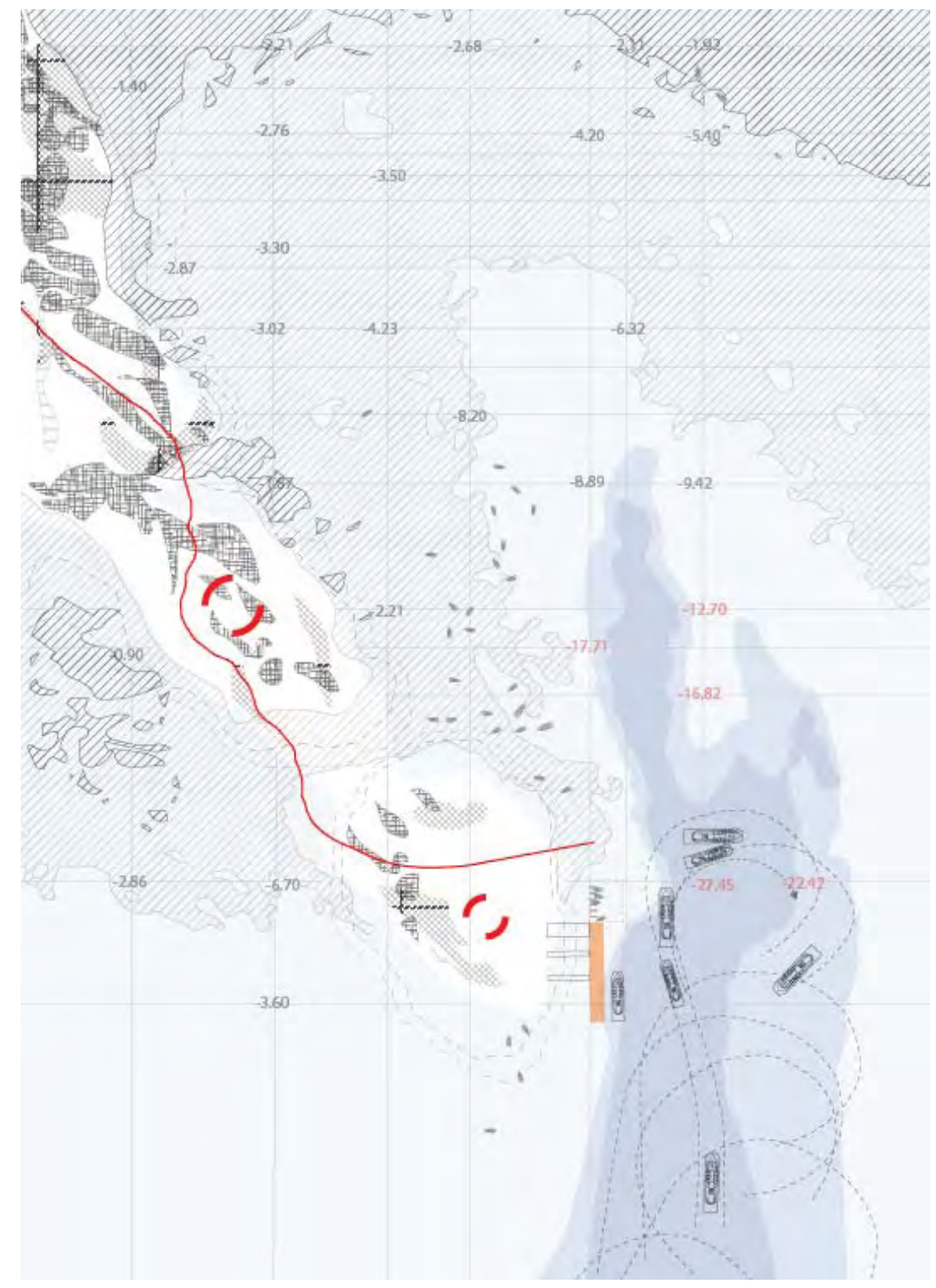




\section{Pro Forma}

\begin{tabular}{|l|l|l|l|}
\hline \multicolumn{1}{|c|}{ Item } & \multicolumn{1}{c|}{ Cost } & \multicolumn{1}{c|}{ Total } & \\
\hline ACQUISITION & & & $1.65 \%$ \\
\hline $\begin{array}{l}\text { Land Acquisition (per } \\
\text { sq.m) }\end{array}$ & 155 & $\begin{array}{l}(5000 \text { sq.m) } \\
775,000\end{array}$ & \\
\hline SITE IMPROVEMENT & & & $65.2 \%$ \\
\hline On-Site Imp. & $30,560,000$ & $30,560,000$ & $5.16 \%$ \\
\hline Off-Site Imp. & $2,423,000$ & $2,423,000$ & \\
\hline CONSTRUCTION & & & $1.84 \%$ \\
\hline $\begin{array}{l}\text { New Construction(per } \\
\text { sq.m) }\end{array}$ & 173 & $\begin{array}{l}(5000 \text { sq.m) } \\
865,000\end{array}$ & $15.99 \%$ \\
\hline Contingency & $7,517,096$ & $7,517,096$ & $0.27 \%$ \\
\hline permits (per sq.m) & 25 & $\begin{array}{l}(5000 \text { sq.m) } \\
125,000\end{array}$ & $0.16 \%$ \\
\hline Furnishings & 75,000 & 75,000 & $4.7 \%$ \\
\hline Engineering & $2,127,480$ & $2,215,480$ & $5.2 \%$ \\
\hline Site Utilities & $2,444,000$ & $2,444,000$ & $100 \%$ \\
\hline DEVELOPMENT COST & & $47,000,000$ & \\
\hline
\end{tabular}




\begin{tabular}{|c|c|c|c|c|c|c|}
\hline REVENUES & $\begin{array}{l}\text { Shipping } \\
\text { Cargo }\end{array}$ & $\begin{array}{l}\text { Shipping } \\
\text { Petroleum }\end{array}$ & Fisheries & Tourism & Grants & $\begin{array}{l}\text { Effective } \\
\text { Gross } \\
\text { Income }\end{array}$ \\
\hline Year1 & $2,139,500$ & 336,000 & 912,515 & 14,000 & --- & $3,402,015$ \\
\hline Year2 & $2,237,098$ & 367,900 & $1,064,635$ & 17,780 & --- & $3,687,413$ \\
\hline Year3 & $2,798,000$ & 410,980 & $2,359,235$ & 25,780 & --- & $5,593,995$ \\
\hline Year4 & $2,989,000$ & 480,890 & $2,600,275$ & 36,067 & --- & $6,106,232$ \\
\hline Year5 & $3,000,143$ & 510,000 & $2,800,000$ & 42,980 & --- & $6,353,123$ \\
\hline Year6 & $3,329,089$ & 538,760 & $2,860,000$ & 48,563 & --- & $6,776,412$ \\
\hline Year7 & $3,568,000$ & 559,870 & $3,000,239$ & 53,780 & --- & $7,181,889$ \\
\hline Year8 & $3,678,000$ & 591,890 & $3,100,672$ & 62,280 & --- & $7,432,842$ \\
\hline Year9 & $3,879,654$ & 610,000 & $3,200,872$ & 67,346 & --- & $7,757,872$ \\
\hline Year10 & $3,989,000$ & 623,980 & $3,250,000$ & 71,540 & --- & $7,934,520$ \\
\hline $\begin{array}{l}\text { Operating } \\
\text { Expenses }\end{array}$ & $\begin{array}{l}\text { Management } \\
\text { Fee }\end{array}$ & Maintenance & Insurance & $\begin{array}{l}\text { Terminal } \\
\text { Operating } \\
\text { Cost }\end{array}$ & $\begin{array}{l}\text { Total } \\
\text { Operating } \\
\text { Expenses }\end{array}$ & $\begin{array}{l}\text { Net Operating } \\
\text { Income }\end{array}$ \\
\hline Year1 & 209,181 & 392,116 & 564,457 & 980,659 & $2,146,413$ & $1,255,602$ \\
\hline Year2 & 250,000 & 422,121 & 610,672 & $1,127,000$ & $2,409,793$ & $1,277,620$ \\
\hline Year3 & 277,121 & 450,000 & 637,987 & $1,328,890$ & $2,693,998$ & $2,899,997$ \\
\hline Year4 & 301,122 & 477,876 & 789,000 & $1,430,000$ & $2,997,998$ & $3,108,234$ \\
\hline Year5 & 324,000 & 495,124 & 820,000 & $1,560,876$ & $3,200,000$ & $3,153,123$ \\
\hline Year6 & 341,000 & 504,674 & 832,239 & $1,588,120$ & $3,266,033$ & $3,510,379$ \\
\hline Year7 & 354,120 & 552,132 & 849,000 & $1,590,020$ & $3,345,272$ & $3,836,617$ \\
\hline Year8 & 377,000 & 571,162 & 890,154 & $1,671,429$ & $3,509,745$ & $3,923,097$ \\
\hline Year9 & 389,163 & 581,325 & 901,000 & $1,699,025$ & $3,570,513$ & $4,187,359$ \\
\hline Year10 & 402,143 & 592,091 & 988,541 & $1,729,019$ & $3,711,794$ & $4,222,726$ \\
\hline
\end{tabular}




$$
\begin{gathered}
\text { APPENDIX B - } \\
\text { SKETCHES \& PROCESS }
\end{gathered}
$$
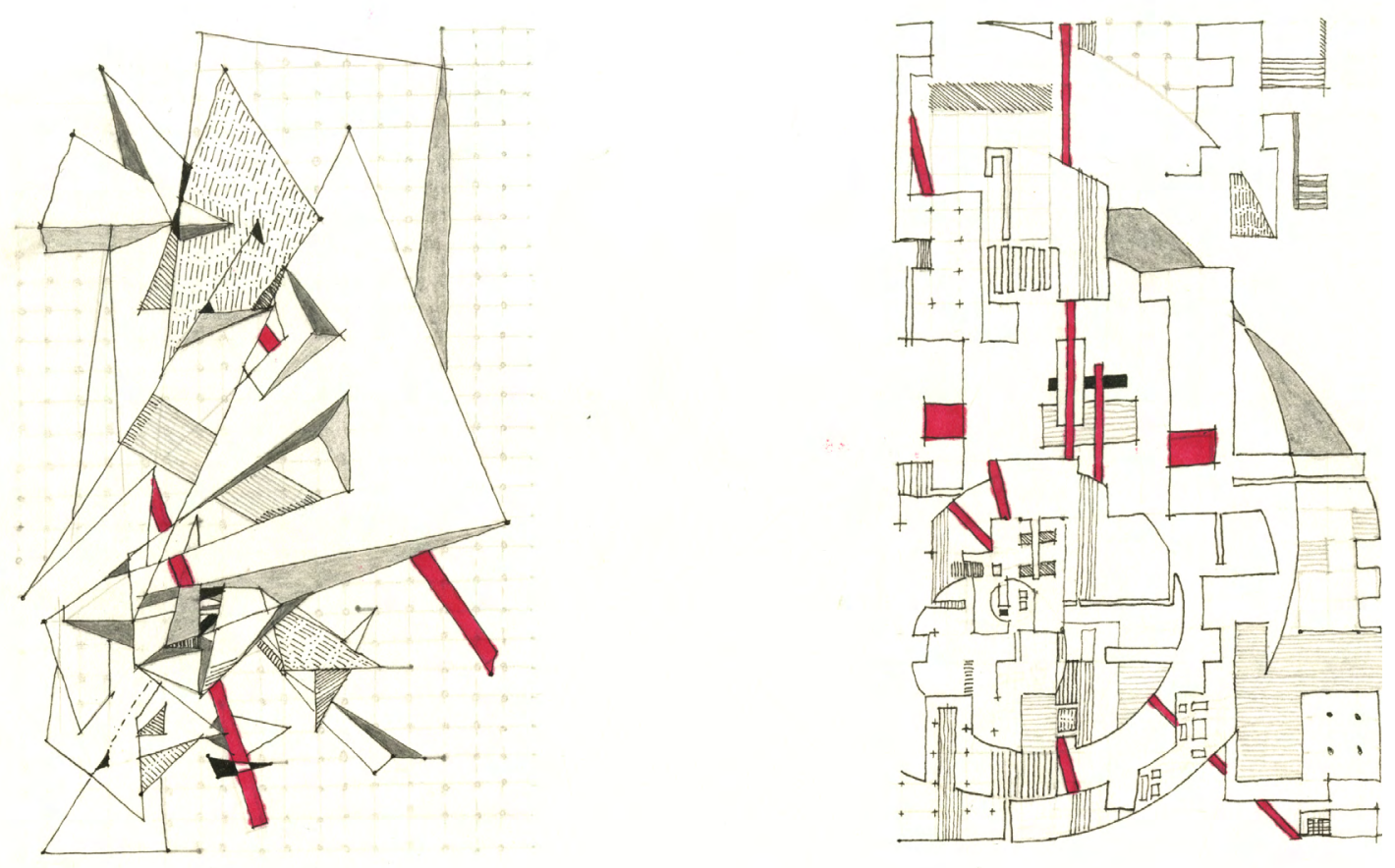

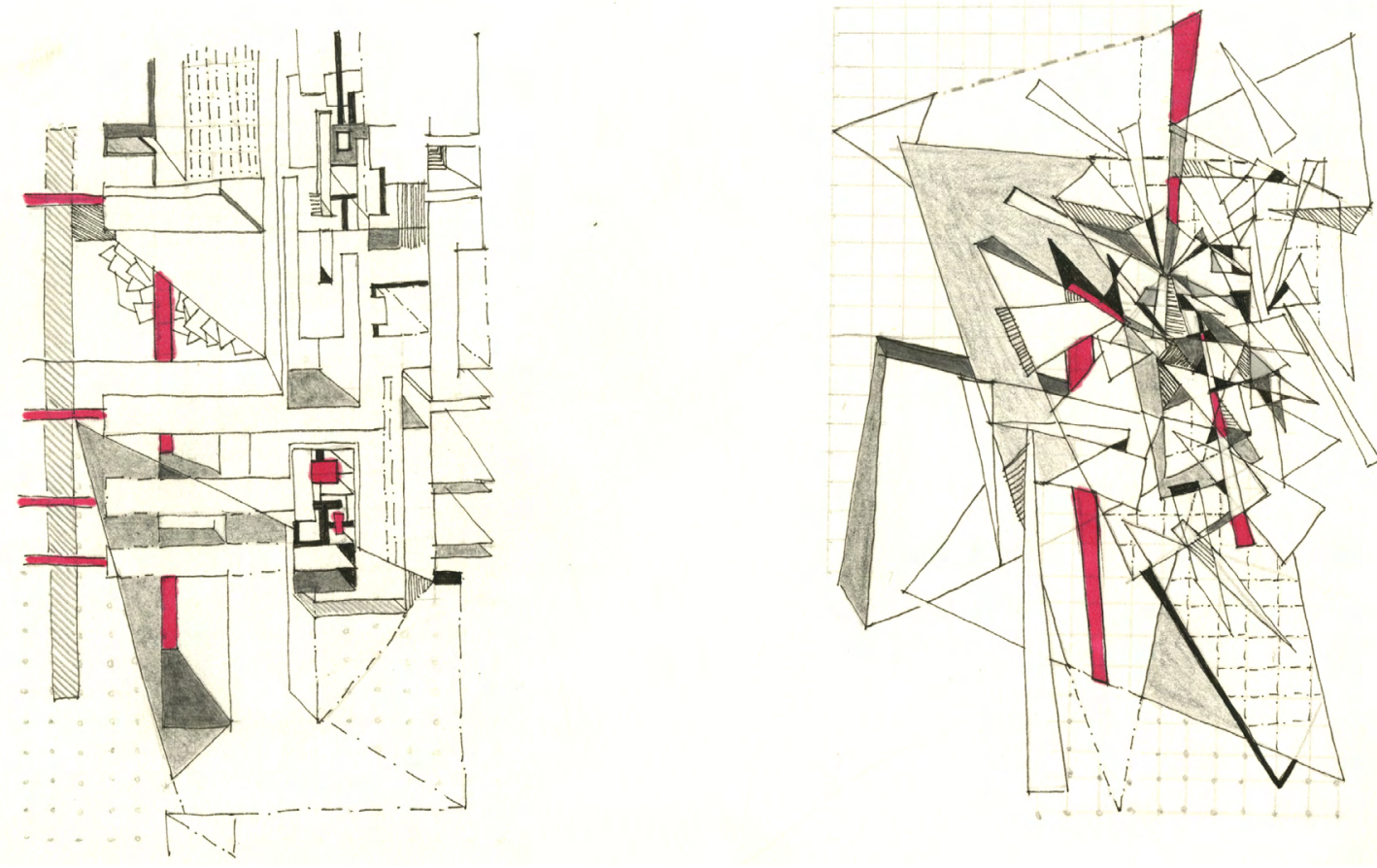


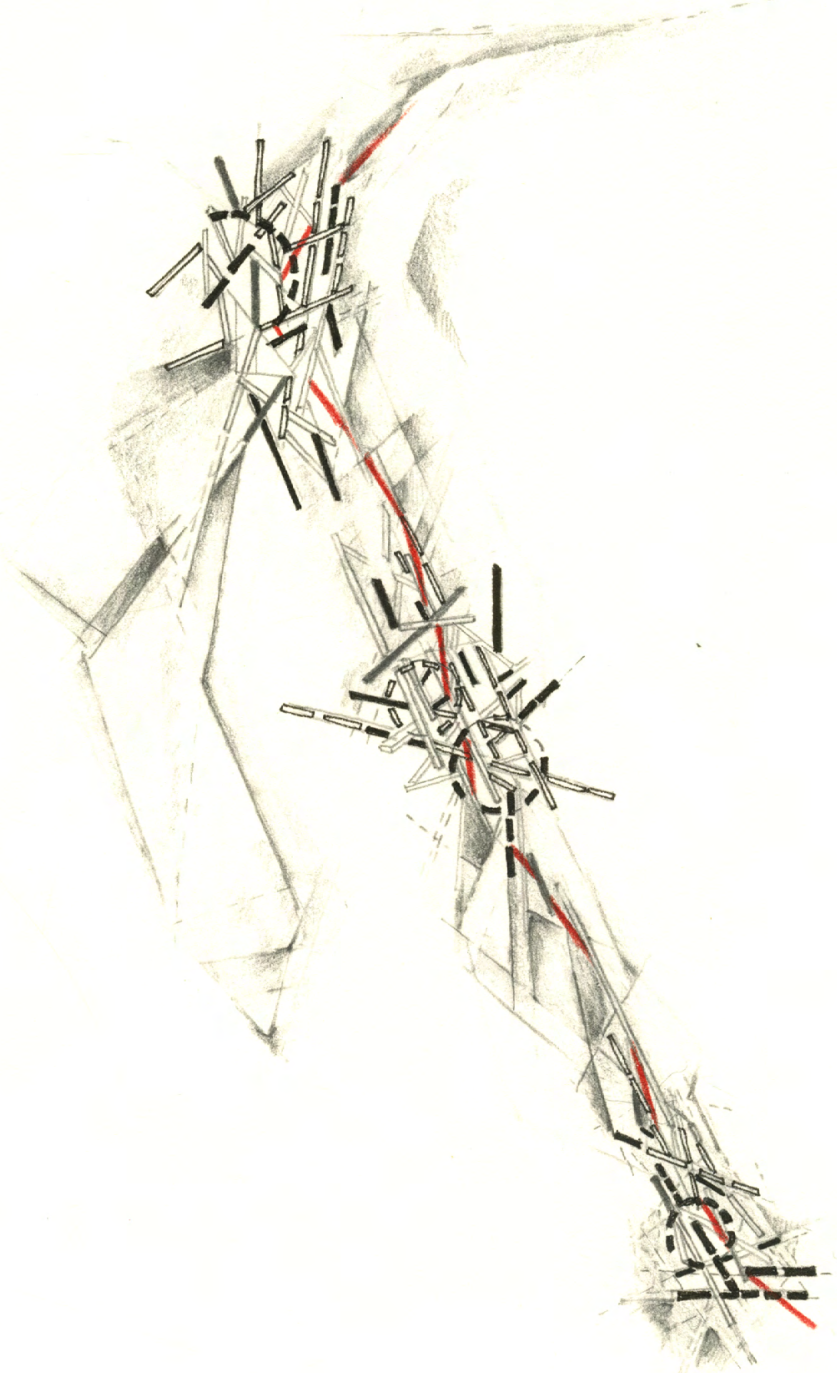

Lifeline analysis 


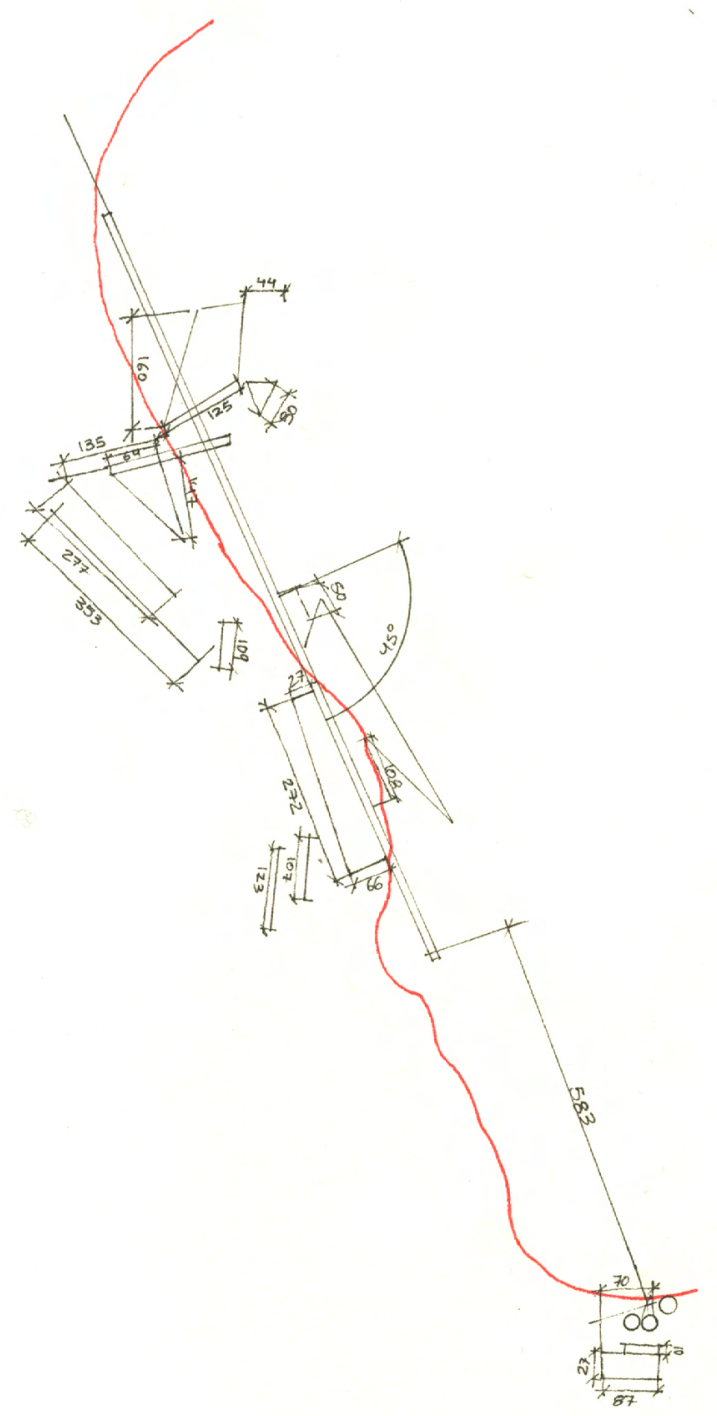

Lifeline analysis 


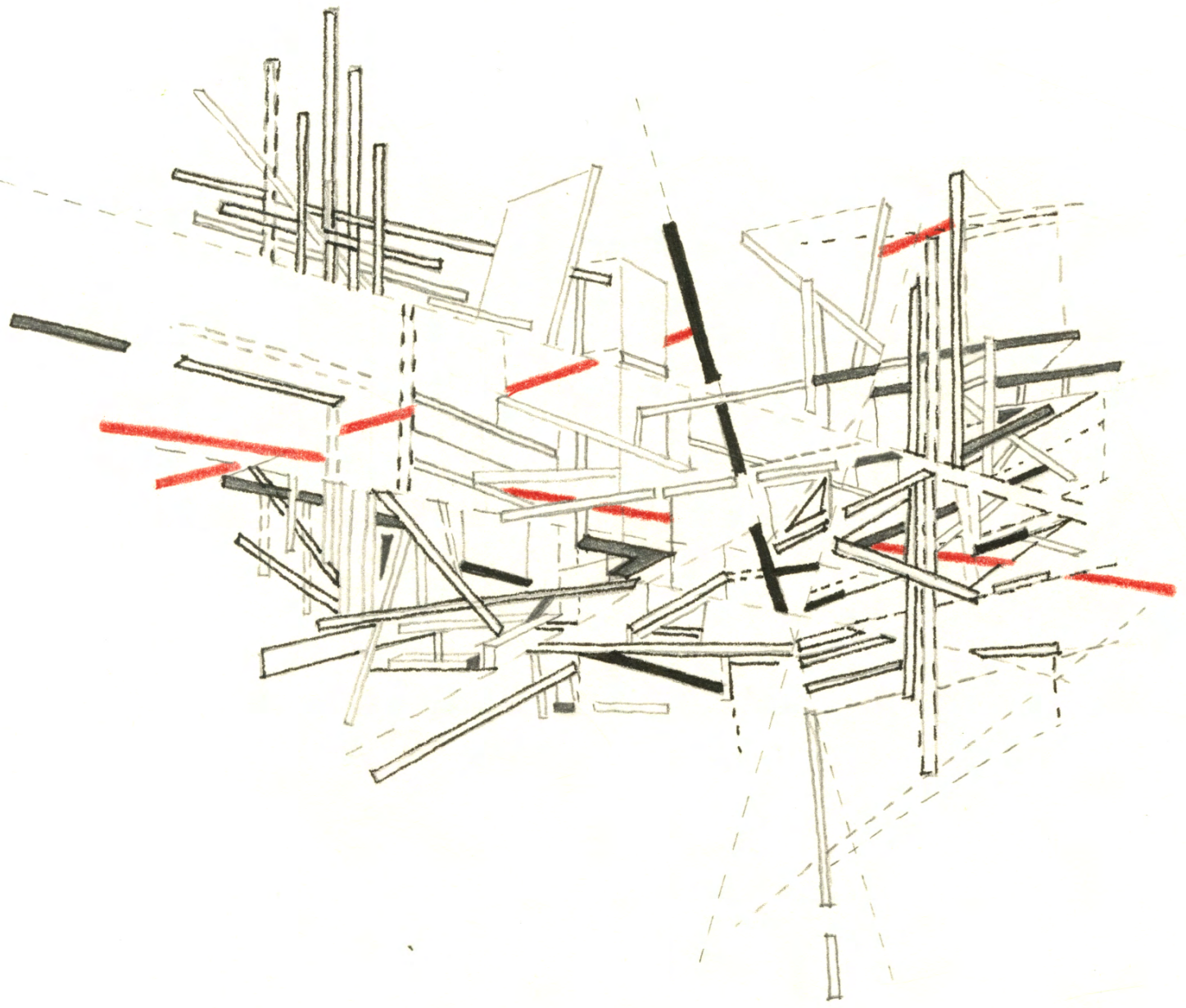




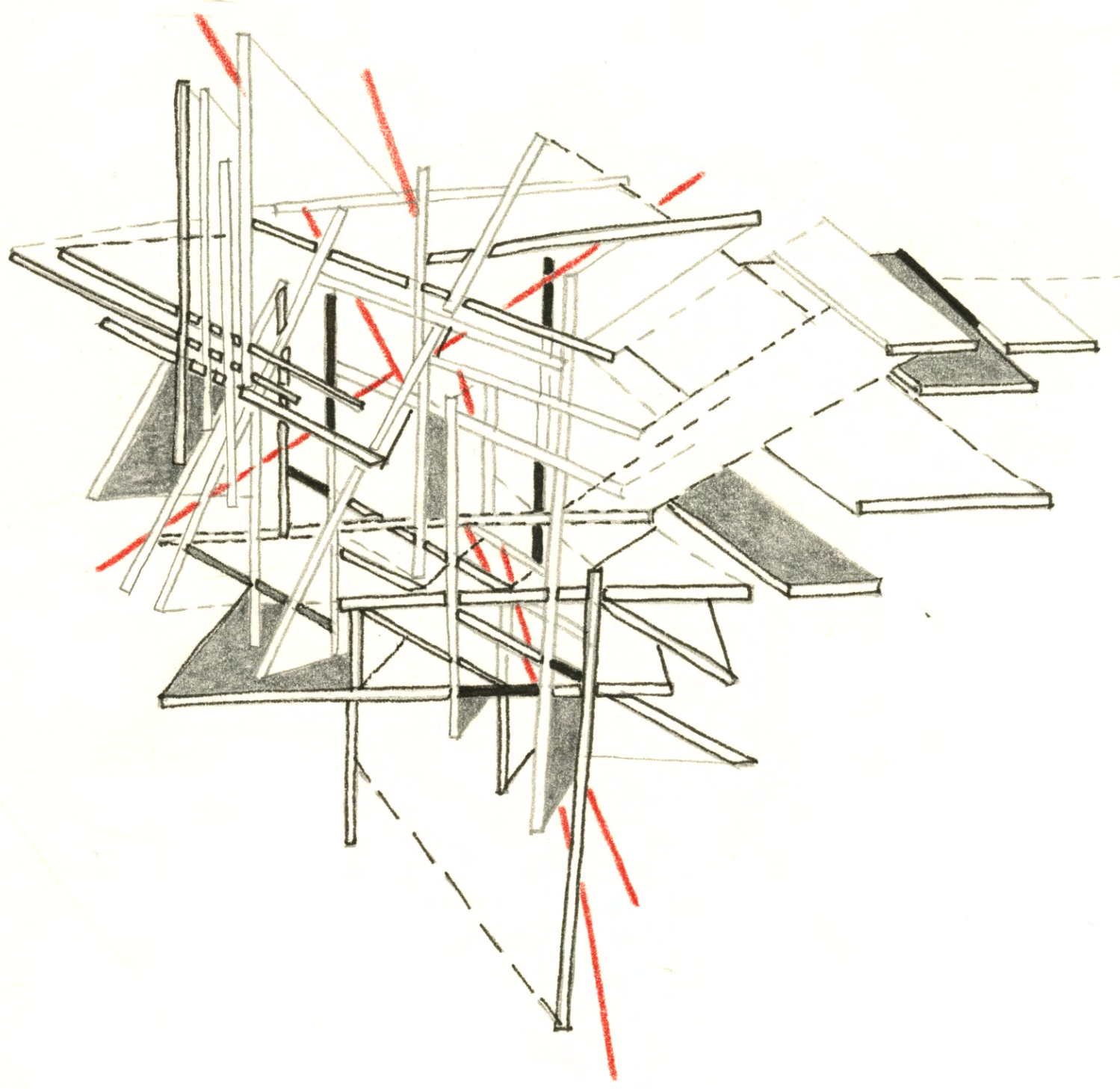




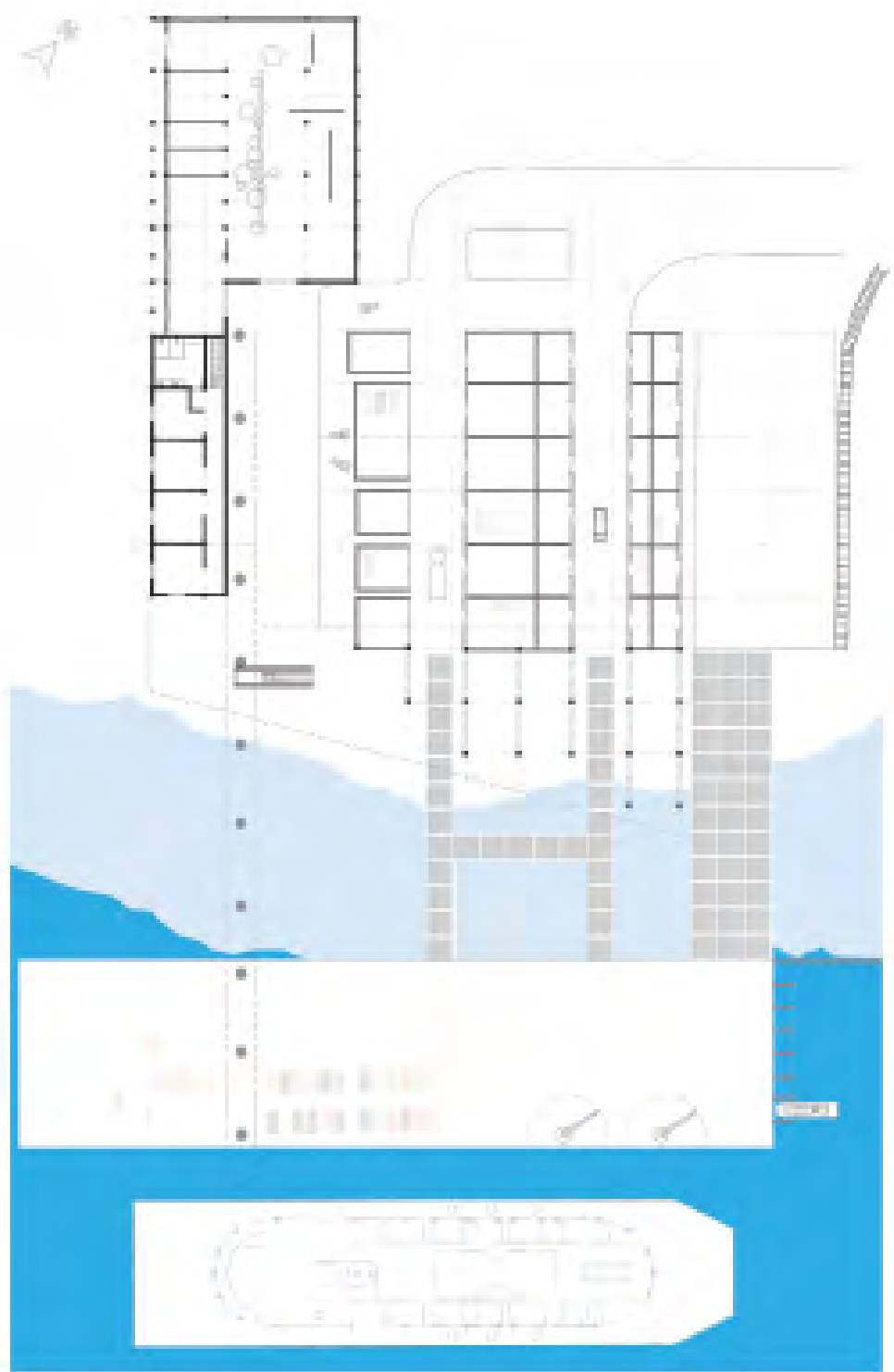

Port-Ground level flocor plan

$1: 100$ 


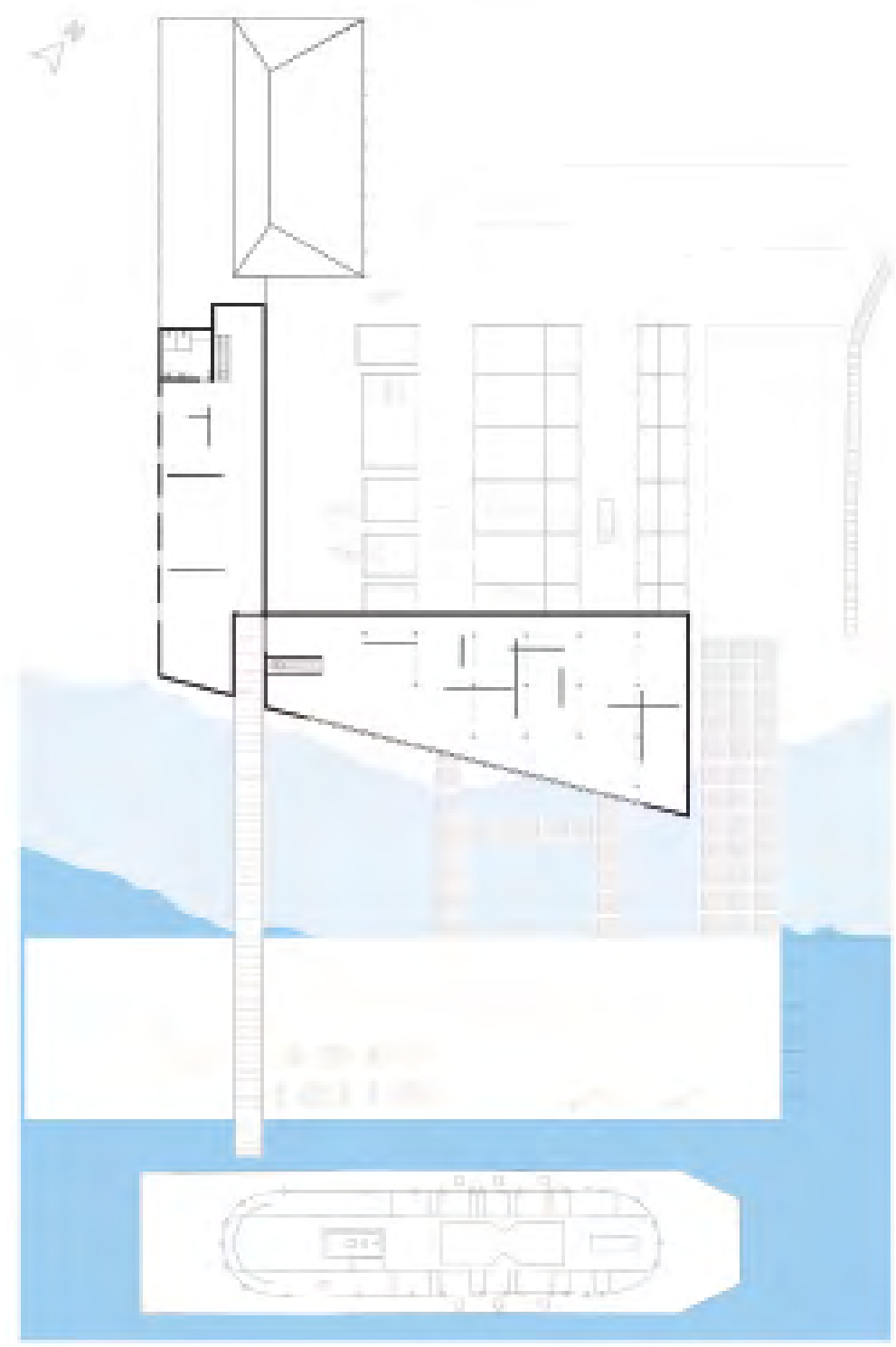

Port Level foor plan

1:100

Port-Level2 Floor Plan 


\section{ENDNOTES}

1 Lola Sheppard. Mason White. MANY NORTHS, Spatial practice in a polar territory. New York: Actar Publishers. 2017. p 68.

2 Lola Sheppard. Mason White. MANY NORTHS, Spatial practice in a polar territory. New York: Actar Publishers. 2017.

3 Nicole GOMBAY. "Today is today and tomorrow is tomorrow: Reflections on Inuit Understanding of Time and Place." In Collignon B. \& Therrien M. (eds). 2009. Orality in the 21st century: Inuit discourse and practices. Proceedings of the 15 th Inuit Studies Conference. Paris: INALCO.

4 Jack Hicks. Bjerregaard, Peter. Berman, Matt. The Transition from the Historical Inuit Suicide Pattern to the Present Inuit Suicide Pattern: Moving Forward, Making a Difference," in the Aboriginal Policy Research Series. Volume4. Thompson Educational Publishing,lnc., 2013. p45.

5 lbid.

6 Wikipedia. https://en.wikipedia.org/wiki/Deconstructivism.

7 lbid.

8 Lola Sheppard. Mason White. MANY NORTHS, Spatial practice in a polar territory. New York: Actar Publishers. 2017. p142.

9 Nicole GOMBAY. "Today is today and tomorrow is tomorrow: Reflections on Inuit Understanding of Time and Place." In Collignon B. \& Therrien M. (eds). 2009 . Orality in the 21 st century: Inuit discourse and practices. Proceedings of the 15 th Inuit Studies Conference. Paris: INALCO.

10 Ibid, p 7 .

11 lbid. 
12 Lola Sheppard. Mason White. MANY NORTHS, Spatial practice in a polar territory. New York: Actar Publishers. 2017 . p256.

13 Aaluk Consulting Inc. Gartner Lee Limited, and Anderson, Chris. "Strategic Plan for the Iqaluit Deepwater Port Project". (2005)

14 lbid.

15 lbid.

16 Aaluk Consulting Inc. Gartner Lee Limited, and Anderson, Chris.

"Strategic Plan for the Iqaluit Deepwater Port Project". (2005)

17 Ibid.

18 lbid.

19 lbid.

20 lbid.

21 lbid.

22 Ibid.

23 Ibid.

24 Lola Sheppard. Mason White. MANY NORTHS, Spatial practice in a polar territory. New York: Actar Publishers. 2017. p262. 


\section{APPENDIX C - \\ BIBLIOGRAPHY}

Aaluk Consulting Inc. Gartner Lee Limited, and Anderson, Chris. "Strategic Plan for the Iqaluit Deepwater Port Project". (2005)

Freeman,Milton.M.R. Bogoslovskaya, Lyudmila.

Caulfield, Richard.A. Egede, Ingmar. Krupnik, Igor.l. and Steven-

son, Mark.G. INUIT, WHALING, AND SUSTAINABILITY. London: A division of sage publications, Inc. 1998.

GEERTZ, Clifford.1973 "Person, Time, and Conduct in Bali," in The Interpretation of Cultures, U.S.A., Basic Books: 360-411.

GOMBAY, Nicole. "Today is today and tomorrow is tomorrow: Reflections on Inuit Understanding of Time and Place." In Collignon B. \& Therrien M. (eds). 2009 . Orality in the 21 st century: Inuit discourse and practices. Proceedings of the 15 th Inuit Studies Conference. Paris: INALCO.

Grillo, Paul Jacques. Form Function And Design. New York: Dover Publications, Inc. 1960.

Harrington, Richard. The Inuit Life As It Was. Edmonton: Hurtig Publishers. 1981.

Hicks, Jack. Bjerregaard, Peter. Berman, Matt. The Transition from the Historical Inuit Suicide Pattern to the Present Inuit Suicide Pattern: Moving Forward, Making a Difference," in the Aboriginal Policy Research Series. Volume4. Thompson Educational Publishing,Inc., 2013. 
Hunting the Largest Animals, Native whaling in the Western Arctic and Subarctic. Edited by Mc Cartney, P.Allen. University of Alberta. 1995.

McElroy, Ann. Nunavut Generations, Change and Continuity in Canadian Inuit Communities. Long Grove, Illinois: Waveland Press, Inc. 2008.

Nisbet, B. (1997, Winter). Concepts of Space and Time in Inuit Art.

Volume 4, Issue 2. Retrieved March 3, 2017, from http://quod.lib.umich. edu/j/jii/4750978.0004.217/--concepts-of-space-and-time-in-inuitart?rgn=main;view=fulltext; 1 = American Studies

Schott-Billmann, France. Primitive Expression and Dance Therapy when dancing heals. Translated by Holden, Terence. New York: Routledge Taylor \& Francis Group. 2015

Sheppard,Lola. White, Mason. MANY NORTHS, Spatial practice in a polar territory. New York: Actar Publishers. 2017.

Wikipedia. https://en.wikipedia.org/wiki/Deconstructivism. 
